\title{
GRAU DE ADESÃO AO TRATAMENTO COM ANTI-RETROVIRAIS ENTRE INDIVÍDUOS HIV POSITIVOS ATENDIDOS NO HOSPITAL UNIVERSITÁRIO DE SANTA MARIA
}

\author{
Adherence to antiretroviral therapy for HIV-infected patients receiving HIV primary care \\ at University Hospital in Santa Maria, RS, Brazil.
}

Juliana S. Saldanha ${ }^{1}$, Claudia S. Andrade², Sandra T. Beck ${ }^{3}$

\begin{abstract}
RESUMO
Este estudo qualitativo avaliou, por um período de seis meses, o grau de adesão a terapia anti-retroviral, entre 898 indivíduos maiores de 15 anos, que recebem medicamentos para o controle da infecção pelo vírus da Imunodeficiência Humana (HIV), junto a farmácia de doenças infectocontagiosas, no Hospital Universitário de Santa Maria (HUSM). A faixa etária mais prevalente da população estudada foi a de 30 - 49 anos, sendo 517 do sexo masculino (58\%) e 381 do sexo feminino (42\%). A maioria dos pacientes (72\%) apresentou bom nível de adesão. Apenas $7 \%$ dos indivíduos abandonaram o tratamento. Conclui-se que manter uma adequada adesão ao tratamento por longo prazo, é um trabalho que necessita constante vigilância. A atenção farmacêutica e clínica no acompanhamento e tratamento da infecção pelo HIV aumentaram a expectativa e melhorou a qualidade de vida dos indivíduos avaliados.

Palavras chave: HIV, adesão, tratamento.
\end{abstract}

\section{SUMMARY}

This qualitative study evaluated, during six months, the adherence to antiretroviral therapy among 898 patients who were more than 15 years old and have received the medications to the control of the infection by the Human Immunodeficiency Virus (HIV) at the University Hospital of Santa Maria (HUSM) pharmacy. The age of the participants was between 30 and 49 years old, being 517 male (58\%) and 381 (42\%) female. The majority of the patients (72\%) showed a good level of adherence. Only $7 \%$ of the individuals abandoned the treatment. One concludes that it is needed a constant monitoring for keeping adequate adhesion to the treatment for a long time. The pharmaceutical and clinical attention in the accompaniment and treatment of the infection by the HIV had increased the expectation and improved the quality of life of the evaluated individuals.

Key words: HIV, adherence, treatment

\section{INTRODUCÃO}

A síndrome da imunodeficiência adquirida (AIDS) é uma doença pandêmica que tem como agente etiológico o vírus HIV (Humam Immunodeficiency Virus), um retrovírus pertencente à subfamília Lentivirinae, possuindo RNA como material genético. $\mathrm{O}$ alvo principal do vírus HIV durante a infecção é o linfócito T $\mathrm{CD}^{+}{ }^{+}$

Em 13 de novembro de 1996, foi sancionada a lei 9.313, que garante aos portadores do vírus HIV e AIDS o direito de receber gratuitamente, pelo Sistema Único de Saúde (SUS), todos os medicamentos necessários ao seu tratamento ${ }^{2}$. Essa lei, além de servir como um instrumento legal para reivindicação de direitos, marca o início de grandes mudanças no âmbito da política de assistência farmacêutica aos portadores de HIV/ $\mathrm{AIDS}^{3,4}$. O acesso universal à terapia anti-retroviral, associado ao uso mais difundido de quimioprofilaxia para infecções oportunistas e a oferta de outros tipos de assistência, tem possibilitado a redução das internações hospitalares e dos óbitos por AIDS no Brasil ${ }^{3}$.

Trabalho realizado no Hospital Universitário de Santa Maria/Universidade Federal de Santa Maria -UFSM - RS

${ }^{1}$ Aluna do curso de Farmácia da UFSM

${ }^{2}$ Farmacêutica responsável pela Farmácia Hospitalar do Hospital Universitário de Santa Maria/UFSM

${ }^{3}$ Prof $^{a}$ Dr $^{\mathrm{a}}$ da disciplina de Imunologia Clínica. Departamento de Análise Clínicas e Toxicológicas. Curso de Farmácia, UFSM-RS 
A infecção pelo HIV não determina a AIDS imediatamente, e os aspectos de como e quando os pacientes infectados pelo HIV irão progredir para a expressão da doença permanecem controversos. A infecção primária pelo HIV é assintomática na maioria dos casos, mas algumas vezes causa uma doença semelhante à influenza, com abundância de vírus no sangue periférico e uma queda marcante dos níveis dos linfócitos $\mathrm{T} \mathrm{CD} 4{ }^{+}$circulantes. Essa viremia aguda está associada, em virtualmente todos os pacientes, com a ativação dos linfócitos $\mathrm{T} \mathrm{CD}^{+}$, que matam as células infectadas pelo HIV, e, subseqüentemente, com a produção de anticorpos, ou soroconversão ${ }^{5}$. Esta infecção pode ser dividida em quatro fases clínicas. A fase inicial caracteriza-se pela síndrome retroviral aguda, na qual ocorre uma súbita diminuição na contagem de linfócitos $\mathrm{T} \mathrm{CD}^{+}$e altos níveis de carga viral plasmática. Em seguida, o número de linfócitos $\mathrm{T} \mathrm{CD}^{+}{ }^{+}$aumenta, porém, na maioria das pessoas infectadas, não retorna aos níveis pré-infecção, constituindo a segunda fase ou fase assintomática, também conhecida como latência clínica. A terceira é a fase sintomática precoce, com a ocorrência de manifestações, dentre elas sudorese noturna, adenite tuberculosa, sinusopatias, candidíase oral e vaginal. Essas manifestações clínicas são mais freqüentes em indivíduos com imunodeficiência em fase inicial, porém podem acontecer em pacientes imunocompetentes. Aúltima fase, também chamada de fase sintomática, caracteriza-se pela contagem de linfócitos $\mathrm{T} \mathrm{CD}^{+}<200$ céls $/ \mathrm{mm}^{3}$ e pelo aparecimento de doenças oportunistas, definindo assim o quadro de AIDS ${ }^{6}$. Por esta razão, o quadro clínico da AIDS é caracterizado em função da contagem sangüínea de linfócitos T CD4 ${ }^{+}$no indivíduo infectado com o HIV, e da caracterização das condições clínicas relacionadas à infecção com o HIV ${ }^{1}$.

A evolução do conhecimento e os avanços na utilização de recursos diagnósticos e terapêuticos, principalmente com o advento da terapia combinada de alta potência (HAART) em 1996, tem se mostrado decisivos no aumento da sobrevida de indivíduos com infecção pelo HIV. No Brasil, dentre as estratégias para combater a epidemia destaca-se a política de distribuição dos medicamentos anti-retrovirais aos portadores do HIV que necessitam de tratamento. Vários indicadores evidenciam o efeito positivo dessa política adotada no país, como uma redução da mortalidade (50\%), diminuição das internações hospitalares (80\%), redução da incidência de infecções oportunistas, e da transmissão vertical, dentre outros ${ }^{7}$. A efetividade da terapia HAART é dependente de uma estratégia de adesão ao regime prescrito, pois o uso irregular ou em doses insuficientes pode propiciar o desenvolvimento de vírus resistente. Conseqüências de uma baixa adesão incluem limitações terapêuticas para o paciente e ameaça para a saúde pública, diante da possibilidade de transmissão de vírus multirresistentes ${ }^{8,9}$.

A adesão terapêutica se torna importante no tratamento da infecção pelo HIV, geralmente por dois motivos: a adesão terapêutica leva a uma diminuição da carga viral, quando se omite uma dose do medicamento, pois, mesmo que seja apenas uma vez, o vírus tem a oportunidade de reproduzir-se mais rapidamente. Portanto, manter a multiplicação do vírus ao mínimo é fundamental para prevenir as doenças relacionadas com a AIDS; a adesão ao tratamento previne a resistência ao medicamento, pois, quando se omite doses, podem desenvolver-se cepas de HIV resistentes aos medicamentos que estão sendo administrados. Portanto, a administração correta dos medicamentos aumenta a probabilidade de êxito do tratamento ${ }^{10}$.

A inadequada adesão ao tratamento das doenças crônicas é um problema mundial de grande magnitude. Nos países desenvolvidos a adesão média é de $50 \%$ e nos países em desenvolvimento, este percentual é ainda menor. ${ }^{11}$

Fatores como a quantidade de medicamentos, as reações adversas (intolerância), a necessidade de períodos de jejum, a incompatibilidade entre as drogas, a dificuldade na compreensão das metas da terapia e da implicação do seu uso inadequado, contribuem para dificultar o processo terapêutico ${ }^{12,13}$. Pode-se considerar ainda a complexidade posológica e a adesão do paciente ao tratamento por períodos prolongados como um desafio à efetividade dos recursos terapêuticos disponíveis contra a AIDS ${ }^{13,14}$.

A não adesão aos novos medicamentos para AIDS é considerada um dos mais ameaçadores perigos para a efetividade do tratamento, no plano individual, e para a disseminação de vírus-resistência, no plano coletivo. Isto porque os novos regimes terapêuticos parecem exigir do indivíduo que adere o tratamento integração complexa entre conhecimentos, habilidades e aceitação, além de outros importantes fatores ligados ao ambiente e ao cuidado à saúde 15

A participação do farmacêutico nos grupos existentes na área da unidade de saúde, trazendo informações sobre os medicamentos, respondendo a dúvidas e questões sobre os medicamentos e tratamentos poderá contribuir para a melhoria da adesão e dos resultados dos tratamentos. Tem ainda a função de integração na equipe e com os pacientes ${ }^{16}$.

O presente trabalho teve como objetivo verificar o grau de adesão à terapia anti-retroviral entre pacientes HIV positivos, buscando informações que permitam desenvolver e programar intervenções que auxiliem o paciente e o cuidador na adesão à terapia medicamentosa.

\section{METODOLOGIA}

Desenvolveu-se um estudo qualitativo, observacional, através da análise dos dados, compilados por meio da estatística descritiva, entre janeiro e junho de 2008. Estes dados se encontram no Sistema de Controle Logístico de Medicamentos (SICLOM). Esse sistema foi desenvolvido pela Coordenação Nacional de Doenças Sexualmente Transmissíveis/ AIDS (CN- 
DST/AIDS), que permite o controle do fluxo de dados e do estoque, fornecendo ainda uma série de informações administrativas e outras relacionadas ao perfil clínico e demográfico do paciente ${ }^{17}$.

A amostra estudada consistiu de indivíduos maiores de 15 anos que recebem medicamentos para o controle da infecção pelo HIV, na Farmácia de doenças infectocontagiosas do Hospital Universitário de Santa Maria (HUSM).

Foi utilizado como critério de exclusão indivíduos que receberam medicamentos anti-retrovirais como medida profilática (exposição ocupacional, exposição sexual), gestantes, parturientes, recém nascidos de mãe HIV positiva e crianças de zero a 15 anos.

Vários métodos podem ser utilizados para avaliar a adesão à medicação (contagem de comprimidos, concentração de fármacos e marcadores biológicos, questionários) ${ }^{18}$. No presente estudo, foi utilizado o método validado por Steiner (1988), que se baseia na frequencia de dispensação dos medicamentos ${ }^{19}$. O período considerado para análise foi de 6 meses (fevereiro a julho de 2008) perfazendo um total de 180 dias. O último dia da análise foi estipulado como referência, para determinar o número de indivíduos que apresentavam atraso na retirada do medicamento junto à farmácia, a qual é realizada normalmente a cada 30 dias.

Para determinar o grau de adesão à terapia, foi subtraído do total de dias (180), o número de dias em atraso na retirada do medicamento.

A população foi avaliada e dividida em grupos, considerandose três parâmetros:

1) boa adesão: menos de 29 dias de atraso ( > 95\% de adesão) que corresponde a retirada dentro do período estipulado.

2) zona crítica: entre 29 - 74 dias de atraso( entre 95 $70 \%$ de adesão),

3) má adesão: mais de 74 dias de atraso( $<70 \%$ de adesão), onde provavelmente o paciente não procedeu corretamente em relação a administração do medicamento.

Indivíduo apresentando mais de 180 dias de atraso na retirada do medicamento foi considerado como abandono do tratamento. Este critério foi estipulado pela Secretaria Estadual de Saúde do Rio Grande do Sul, de acordo com a política de controle de DST/ AIDS.

O presente trabalho foi avaliado e aprovado pelo Comitê de Ética em Pesquisa da UFSM CAAE: 0119.0.243.000-08 .

\section{RESULTADOS}

Dos 898 indivíduos HIV positivo estudados, verificou-se que 517 eram do sexo masculino (58\%) e 381 do sexo feminino (42\%), resultando uma relação de 1,35 homens para cada mulher infectada. A maioria dos indivíduos tinha menos de 50 anos, sendo a faixa etária mais prevalente aquela onde se encontravam indivíduos entre 30 a 39 anos, com idade média de 39,5 anos.
Tabela 1. Distribuição da população estudada segundo sexo e idade

\begin{tabular}{|c|c|}
\hline Característica & $\mathrm{N}(\%)$ \\
\hline \multicolumn{2}{|l|}{ Sexo } \\
\hline Masculino & $517(58)$ \\
\hline Feminino & $381(42)$ \\
\hline \multicolumn{2}{|l|}{ Idade (anos) } \\
\hline 16-19 & $3(0,3)$ \\
\hline $20-29$ & $145(16,01)$ \\
\hline 30-39 & $347(38,7)$ \\
\hline $40-49$ & 253 )28,2) \\
\hline$>50$ & $150(16,7)$ \\
\hline
\end{tabular}

O grau de adesão ao tratamento foi determinado através da freqüência de retirada dos medicamentos, uma vez que não foi realizado questionário para levantamento de dados que permitissem conhecer o hábito dos pacientes quanto à conduta em relação ao horário de ingestão das drogas e outros detalhes sobre sua rotina. Porém, este é o primeiro passo para selecionar os indivíduos que necessitam de uma maior informação sobre a importância de todos os cuidados necessários para que não ocorra uma falha medicamentosa.

Baseado na frequiência de retirada do medicamento, entre a população estudada, pode-se considerar que ocorreu uma alta adesão à terapia com anti-retrovirais, com apenas $7 \%$ dos indivíduos não aderindo ao tratamento.

Tabela 2. Distribuição da população estudada segundo adesão ao tratamento

\begin{tabular}{llcl}
\hline Adesão (\%) & Classificação & Pacientes (n) & $\%$ \\
\hline$>95$ & boa adesão & 655 & 73,0 \\
$95-70$ & zona crítica & 89 & 10,0 \\
$<70$ & má adesão & 88 & 10,0 \\
\hline 0 & Abandono & 66 & 7,0 \\
\hline
\end{tabular}

\section{DISCUSSÃO}

Atualmente, a AIDS é sabidamente uma doença crônica e sem cura e a epidemia pelo HIV expandiu-se, podendo ser encontrada em praticamente todos os segmentos populacionais. De 1980 a junho de 2007 foram notificados 474.273 casos de AIDS no país sendo 289.074 no Sudeste, 89.250 no Sul, 53.089 no Nordeste, 26.757 no Centro Oeste e 16.103 no Norte. O vírus alastrou-se, principalmente, através das relações heterossexuais, atingindo um contingente cada vez maior de mulheres. De acordo com documentos do Programa Nacional de DST e AIDS, no ano de 1983 a razão 
entre os casos de infecção pelo HIV entre homens e mulheres era de 40 casos masculinos para um caso feminino ${ }^{20}$. Ao longo do tempo, a razão entre os sexos vem diminuindo de forma progressiva. Em 1985, havia 15 casos da doença em homens para 1 em mulher. Hoje, a relação é de 1,5 para 1, muito próximo a relação encontrada no presente estudo, que foi de 1,35 homens para 1 mulher (tabela 1). Estima-se que uma grande proporção das infecções entre mulheres possa ser atribuída ao comportamento de seus parceiros sexuais masculinos. ${ }^{21}$

Em ambos os sexos, a maior parte dos casos se concentra na faixa etária de 25 a 49 anos confirmando a tendência descrita na literatura (tabela 1). Porém, nos últimos anos, tem se verificado aumento percentual de casos na população acima de 50 anos, em ambos os $\operatorname{sexos}^{20}$.

A adesão terapêutica se refere ao grau em que o comportamento do paciente relacionado com o regime terapêutico se ajusta com o que foi estabelecido com o médico e a equipe responsável pelo tratamento. Inclui a boa disposição para realizar o tratamento e a capacidade para tomar os medicamentos tal como foram prescritos ${ }^{22}$. Em geral, o grau de adesão ao tratamento antiretroviral está determinado pelo número de doses e pelo horário de administração do medicamento. A adesão é essencial para um tratamento adequado, estando associada com o êxito da terapia ${ }^{10}$. É um processo dinâmico e multifatorial que abrange aspectos físicos, psicológicos, sociais, culturais e comportamentais, que requer decisões compartilhadas e corresponsabilizadas entre a pessoa que vive com HIV, a equipe de saúde e a rede social ${ }^{23}$.

A não adesão é a causa mais comum da falha do tratamento constituindo-se na principal variável onde os serviços de saúde podem interferir para aumentar a efetividade da medicação ${ }^{24}$. Esta situação, além de não propiciar o efeito terapêutico desejado, pode contribuir para o desenvolvimento de resistência viral às drogas utilizadas ${ }^{25}$. Estudos com indivíduos em início de tratamento, demonstram que cerca de $40 \%$ dos pacientes desenvolvem falha terapêtica ainda nos primeiros 6 anos, requerendo a adoção de regimes terapêuticos mais complexos e por isso de mais difícil adesão ${ }^{23}$.

Tem-se verificado que altas taxas de adesão à terapia antiretroviral estão diretamente correlacionadas com a supressão viral, a redução das taxas de resistências e melhora na sobrevida do paciente ${ }^{26}$. A literatura especializada estabelece a obtenção deste benefício para indivíduos que realizam a ingestão de medicamentos superior a $95 \%$ das doses de anti-retrovirais. Porém, esta necessidade de adesão superior a 95\% das doses dos regimes é muitas vezes complexa, pois impõe a necessidade de adequar hábitos cotidianos, exigindo mudanças na rotina das pessoas sob tratamento ${ }^{23}$.

No tratamento de pacientes com HIV/AIDS, os estudos referentes à adesão em relação aos agentes anti-retrovirais varia entre $37 \%$ e $83 \%$, dependendo do medicamento estudado e das características demográficas da população ${ }^{11}$.

Segundo estudo feito no Hospital das Clínicas, da
Universidade Federal de Goiás, 71 (55,9\%) pacientes retiravam os anti-retrovirais regularmente, enquanto que $56(44,1 \%) \mathrm{em}$ algum momento após o início do tratamento não retiraram os medicamentos mensalmente ou retiravam de forma irregular. Estes achados mostram uma provável existência de não adesão ao tratamento por um número significante de pacientes ${ }^{27}$. Estudos realizados em Minas Gerais e no Rio Grande do Norte, onde avaliaram a adesão à terapia, a partir da dispensação pela farmácia, verificaram-se taxas de adesão de, $76,5 \%$ e $64,1 \%$, respectivamente ${ }^{28,29}$

Em alguns estudos realizados no Brasil observou-se uma taxa de adesão bem variável, sendo de $69 \%$ em 27 unidades do Estado de São Paulo ${ }^{9}, 85,8 \%$ em hospital dia de Brasília ${ }^{30}$ e 49\% no Serviço de Assistência Especializada (SAE) em HIV/ AIDS da Universidade Federal de Pelotas/RS. ${ }^{31}$.

A proporção de $72 \%$ de indivíduos com boa adesão (tabela 2) provavelmente deva-se ao bom trabalho de assistência farmacêutica realizada junto à farmácia de doenças infectocontagiosas do HUSM, a disponibilidade que o paciente tem de participar do Grupo de Apoio o qual conscientiza o paciente, através de exemplos dos demais, que a decisão de tomar corretamente a medicação depende de cada um. Este grupo, ao mesmo tempo, cria um espaço para tirar dúvidas e relatar quanto às dificuldades de aderir ao tratamento, acesso ao acompanhamento psicológico, à confiança que o paciente deposita no médico e a conscientização do paciente a terapia prescrita.

É Importante ressaltar que a não dispensação dos medicamentos não foi em nenhum momento pela falta do medicamento na farmácia ou falha na dispensação, mas sim pelo não comparecimento do paciente ou responsável ao serviço de farmácia para receber os anti-retrovirais mensalmente. Mesmo sabendo que a adesão ao tratamento não se refere apenas à aquisição do medicamento por parte do paciente, consideramos que o não comparecimento à farmácia, com a conseqüente não retirada dos anti-retrovirais, seja um fator influente e significativo na análise da adesão por parte destes pacientes ao tratamento.

Em relação aos $7 \%$ de indivíduos que abandonaram o tratamento (tabela 2), é necessário um estudo maior deste grupo para identificar as causas deste comportamento. A infecção pelo HIV, em um primeiro momento, pode causar negação, culpa, revolta e depressão, impedindo que o paciente não veja benefícios na terapia. Outros fatores que dificultam a adesão são: desconforto no local de trabalho para tomar o medicamento, perda da hora para tomar o medicamento, esquecimento, desconforto causado pelos efeitos adversos, sensação de estar bem, festas, feriados, fins de semana e viagens, entre outros, já relatado por Willians (1999) ${ }^{32}$.

Segundo Lignani Junior (2001) ${ }^{6}$, a adoção de algumas estratégias específicas podem contribuir para a melhora da adesão ao tratamento: aumentar o aporte de informações; 
disponibilidade da equipe assistente para atender e orientar bem os pacientes, dirimindo suas dúvidas e explicando os procedimentos em linguagem simples e objetiva; participar de grupos de adesão que abordem temas relacionados à adesão, identificando as dificuldades e incentivando a troca de experiências entre os pacientes.

Para Osterberg e Blaschke (2005) ${ }^{22}$, os métodos utilizados para melhorar a adesão podem ser agrupados em quatro categorias: educação do paciente; melhora do esquema de doses; aumento do número de horas de acesso ao serviço de saúde e melhora da comunicação entre médicos e pacientes. Qualquer que seja a estratégia específica para se trabalhar questões da adesão ao tratamento, a informação do usuário sobre seus direitos e a coresponsabilidade com os profissionais de saúde frente ao seu tratamento são imprescindíveis ${ }^{15}$.

Diversas das ações acima citadas são empregadas na Farmácia de doenças infectocontagiosas do HUSM, mostrando que a atenção farmacêutica e clínica no acompanhamento e tratamento da infecção pelo HIV foram extremamente importantes para manter uma adequada adesão ao tratamento. Porém este é um trabalho que necessita constante vigilância, visando sanar os pontos deficientes, para que os benefícios advindos deste processo sejam atingidos

\section{REFERÊNCIAS BIBLIOGRÁFICAS}

1. Peçanha E; Antunes OAC; Tanuri A. Estratégias farmacológicas para a terapia anti-AIDS. Química Nova, Rio de janeiro 2002; 25, (6B):.1108-1116.

2. BRASIL, 1996. Lei No 9.313 de 13 de Novembro de 1996. Dispõe sobre a Distribuição Gratuita de Medicamentos aos Portadores do HIV e Doentes de AIDS. 〈http://www.aids.gov.br/ assistencia/ lei9313.htm> Acesso dia: 25 mai 2008.

3. _____. Ministério da Saúde. Política de Medicamentos de AIDS do Ministério da Saúde. 2000. 〈http://www.aids.gov.br/assistencia/ politica_medic_aids_brasil.htm〉. Acesso dia: 27 ago 2008.

4. ______Ministério da Saúde. Acesso Universal e Gratuito. 2001. <http://www.aids.gov.br/ politica/ Acesso\%20Universal\%20e\%20Gratuito/ acesso.htm>. Acesso dia: 03 jun 2008

5. Janeway CA; Traves P; Walport M. Imunobiologia: O sistema imune na saúde e na doença. 2002. 5. ed. Porto Alegre: Artmed Editora.

6. Júnior LL; Greco DB; Carneiro M. Avaliação da aderência aos anti-retrovirais em pacientes com infecção pelo HIV/Aids. Rev. Saúde Pública, São Paulo; 2001;35( 6):495-501.

7. BRASIL. Ministério da Saúde. Boletim epidemiológico- AIDS.

2002 . > h t t p : // ww w.aids.gov.br/data/Pages/ LUMIS624DE984PTBRIE.htm>. Acesso em: 03 jun 2008.

8. Chesney MA. Factors affecting adherence to anti-retroviral therapy. Clin Infect Dis 2000; 30:Suppl 2: S 171-6.

9. Nemes MIB, Souza MDFMD, Kalichman AO, Grangeiro A, Souza
RDA \& Lopes JF. (1998). Avaliação da aderência ao tratamento por anti-retrovirais de usuários de ambulatórios do sistema público de assistência à AIDS no estado de São Paulo: Coordenação Nacional de DST/AIDS. Série Avaliação no 1. http:// www.aids.gov.br (acessado em 10/Jun/2004).

10. Muños PA; Alzate NAG; Ortega ESH. Guia de atuación farmacêutica en pacientes con VIH/SIDA. Colombia: Maria José Faus Dáder Editora, 2006. p. 77-78.

11. Sabaté $E$. The magnitude of the problem of poor adherence. In: Sabaté E, editor. Adherence to long-term therapies: evidence for action. Geneva: World Health Organization; 2003. p. 7-9.

12. Crespo-Fierro M. Compliance/adherence and care management in HIV disease. J Assoc Nurses AIDS Care 1997; 8(4):43- 54.

13. Sinkoc VM, Figueiredo RM, Colombrini MRC, Cavinato SM, Tomazin C, Gallani MCJ. Dificuldades referidas por pacientes com AIDS na adesão ao tratamento com antiretrovirais. Braz J Infect Dis 1999; 3(Suppl):S60.

14. Figueiredo RM, Sinkoc VM, Gallani MBJ, Tomazin C, Cavinatto SM, Assumpção ISA et al. Adherence of patients with AIDS to treatment with antiretroviral medications: difficulties related and proposition of attenuating measures. Proceedings of the 12th World AIDS Conference; 1998 June-July; Geneva: Conference Record 1998.p.862.

15. Colombrini MRC, Lopes MHBM, Figueiredo RM. Adesão à terapia antiretroviral para HIV/AIDS, Rev. Esc. Enferm USP. 2006; 40(4): 576-81.

16. Gomes CAPG. A Assistência Farmacêutica na Atenção à Saúde. 2007. Belo Horizonte: ed. FUNED.

17. Lima RM, Veloso V. SICLOM: distribuição informatizada de medicamentos para HIV/AIDS. Ação Anti-AIDS 2000; 43: 6-7. 18. Ventura Â. Adherence to anti-retroviral therapy in HIV . Arq Med, 2006, vol.20, no.1-2, p.37-49

19. Steiner JF, Koepsell TD, Fihn S, Inui T. A general method of complience assessment using centralized pharmacy records. Descrition and validation. Med Care 1988;26:814-23

20. BRASIL Ministério da Saúde. AIDS no Brasil. 2007. <http:/ / w w w. a i d s.g o v. b r / d a t a / P a g e s / LUMIS13F4BF21IIEMIDOCE4429BFBAD4595A0DC9FE9327EDC83PTBRIEhtm?. Acesso dia: 13 ago 2008.

21. ______ Ministério da Saúde. AIDS no Brasil. 2007. <http:/ / w w w. a i d s. g o v. b r / d a t a / P a g e s / LUMISE77B47C8IIEMID4DF22DCA39924ABF940A9D67111BDFF6PIBRIEhtm>.

Acesso em: 13 ago 2008 .

22. OSTERBERG L; BLASCHKE T. Adherence to medication. N. Engl. J. Med., 2005; 353(5): 487-497.

23. _______ Ministério da Saúde. Diretrizes para o fortalecimento das ações de adesão ao tratamento para pessoas que vivem com HIV e AIDS. 2007. www http:// bvs m s. s a ude.gov.br/bvs/public a coes/ diretrizes_tratamento_aids.pdf $>$.Acesso dia: 14 mai 2008.

24. Wainberg MA \& Friedland G. Public health 
implications of antiretroviral therapy and HIV drug resistance. JAMA, 1998, 279:1977-1983.

25. Zolopa AR, Shafer R W, Warford A, Montoya JG, Hsu P, Katzenstein D, Merigan TC \& Efron B. HIV-1 genotypic resistance patterns predict response to saquinavir-ritonavir therapy in patients in whom previous protease inhibitor therapy had failed. Ann Intern Med, 1999;131: 813-82.

26. Oarac Office AIDS Research Advisory Council. Guidelines for the use of antiretroviral agents in HIV-1 infected adults and adolescents. 2006. Disponível em: 〈http://aidsinfo.nih.gov $>$ Acesso dia: 11 jul 2008 .

27. Nogueira IAL; Leão ABB; Bueno RR Soares AQ; Carvalho RF. Estudo da dispensação de medicamentos anti-retrovirais a pacientes infectados por HIV no serviço de farmácia do HC-UFG: primeiro passo na implantação da atenção farmacêutica.. Revista Eletrônica de Farmácia 2007; IV (1): 104-112. Disponível em: www.farmacia.ufg.br/revista/ pdf/vol4 1/REF\%20104-112.pdf acesso em 12 jul 2008

Endereço para correspondência:

Departamento de Análises Clinicas e Toxicológicas

Centro de Ciências da Saúde - prédio 26

Universidade Federal de Santa Maria -

Campus Universitário - Camobi

Santa Maria - RS CEP: 97105900

E.mail: sbeck@ig.com.br

FONE: (55) 32208464

FAX: (55) 32208018
28. Júnior PRB. De S. Oportunidades perdidas de redução de AIDS adquirida por transmissão vertical no Brasil. 2004. Dissertação (Mestrado em Saúde Pública) - Escola Nacional de Saúde Pública, Fundação Oswaldo Cruz, Rio de Janeiro.

29. Castilho EA, Szwarcwald CL, Brito AM. Fatores associados à interrupção de tratamento anti-retroviral em adultos com Aids. Rio Grande do Norte, Brasil, 1999 - 2002. Rev Assoc Med Bras 2006; 52 (2): 86-92.

30. de Carvalho CV, Duarte DB, Merchán-Hamann E, Bicudo E, Laguardia J.. Determinantes da aderência à terapia anti-retroviral combinada em Brasília Cad. Saúde Pública, Rio de Janeiro . 2003 19 (2): 593-604

31. da Silveira VL, Drachler Mde L, Leite JC, Pinheiro CA. Characteristics of HIV antiretroviral regimen and treatment adherence. The Braz J. Infect Dis 2003;7(3):194-201.

32. Willians AB. Adherence to highly active antiretroviral therapy. Nurs Clin North Am 1999;34:113-29. 


\title{
AVALIAÇÃO DO ESTADO E TRAÇO DE ANSIEDADE EM INDIVÍDUOS COM DISFUNÇÃO TEMPOROMANDIBULARE ASSINTOMÁTICOS
}

\author{
Evaluation of state and trate of anxiety in individuals with temporomandibular \\ dysfunction and asymptomatic
}

Fernanda Pasinato ${ }^{1}$, Eliane Castilhos Rodrigues Corrêa ${ }^{2}$, Juliana Alves Souza ${ }^{3}$

\begin{abstract}
RESUMO
Diversos distúrbios psicológicos, principalmente o estresse, ansiedade e depressão, podem estar associados com a disfunção temporomandibular (DTM), agindo como importantes colaboradores para a instalação e manutenção desta disfunção. Estados e/ou traços emocionais aliados a fatores estressores de vida podem levar a hábitos disfuncionais orais e conseqüentemente à hiperatividade da musculatura mastigatória, constituindo fatores desencadeantes de dor orofacial. $\mathrm{O}$ objetivo deste estudo foi avaliar a presença do estado e traço de ansiedade em indivíduos assintomáticos e com disfunção temporomandibular. Participaram do estudo 35 voluntários, sendo 20 indivíduos com DTM e 15 assintomáticos. Os participantes foram avaliados para verificação da presença e grau de disfunção temporomandibular (Índice Anamnésico de Fonseca e Índice Anamnésico e Clínico de Disfunção e Estado Oclusal). Após, realizou-se a avaliação do estado e traço de ansiedade por meio do Inventário de Ansiedade Traço-Estado. Observou-se incidência significativamente maior tanto do estado de ansiedade $(43,3$ versus 35,7$)$ como do traço $(48,1$ versus 36,73$)$ de personalidade ansiosa em indivíduos com DTM, quando comparados aos assintomáticos para esta disfunção. Os resultados sugerem que estado e traço de ansiedade podem contribuir para a gênese e perpetuação das disfunções temporomandibulares.
\end{abstract}

Palavras-chave: ansiedade, transtornos da articulação temporomandibular, mastigação.

\section{SUMMARY}

Several psychological diseases, mainly stress, anxiety and depression can be associated to temporomandibular disorder (TMD), acting as important collaborators for the settlement and maintenance of this dysfunction. Emotional states and/ or traits associated to stressor factors can lead to oral dysfunctional habits and, consequently, hyperactivity of masticatory musculature, constituting triggering factors of orofacial pain. The aim of this study was to evaluate the presence of anxiety state or trait in asymptomatic individuals and with temporomandibular disorder. Thirty-five volunteers took part in the study, 20 with TMD and 15 asymptomatic ones. The participants were evaluated for the presence and degree of TMD (Anamnestic Index of Fonseca and Anamnestic and Clinical Index of Dysfunction and Occlusal State). Then, the evaluation of anxiety state and trait was carried out by the State-Trait Anxiety Inventory (STAI). It was observed a significant higher incidence of anxiety state (43.3 versus 35.7$)$ and trait (48.1 versus 36.73 ) in subjects with TMD when comparing them to the asymptomatic individuals. The results suggest that the state and trait of anxiety can contribute for the development and perpetuation of the temporomandibular disorders.

Key Words: anxiety, temporomandibular joint disorders, mastication.

\section{INTRODUÇÃO}

As disfunções temporomandibulares (DTMs) compreendem uma causa comum de dor crônica da região orofacial, sendo considerada como uma das várias manifestações somáticas possíveis presentes em indivíduos que sofrem de distúrbios de ansiedade e/ou submetidos a situações de stress psíquico ${ }^{1}$. Além disso, a etiologia multifatorial das DTMs parece estar relacionada com diversos problemas psicológicos. A ansiedade e o estresse favorecem a descarga das tensões nervosas sobre

Pesquisa realizada no Serviço de Atendimento Fonoaudiológico e Serviço de Odontologia da Universidade Federal de Santa Maria (UFSM), Santa Maria, Rio Grande do Sul, Brasil.

${ }^{1}$ Fisioterapeuta, Mestranda do Programa de Pós-graduação em Distúrbios da Comunicação Humana da UFSM, Santa Maria, RS - Brasil; ${ }^{2}$ Doutora em Anatomia pela FOP-UNICAMP, Professora do departamento de Fisioterapia e Reabilitação, UFSM, Santa Maria, RS - Brasil. ${ }^{3}$ Fisioterapeuta, Mestranda do Programa de Pós-graduação em Distúrbios da Comunicação Humana da UFSM, Santa Maria, RS - Brasil; 
a musculatura mastigatória podendo levar a hábitos disfuncionais orais (tais como bruxismo) e conseqüentemente a hiperatividade da musculatura mastigatória, sendo fator desencadeante de dor orofacial $^{2}$

Os fatores etiológicos mais importantes da DTM pertencem a três grandes grupos: fatores neuromusculares, psíquicos e anatomo-oclusais. Neste contexto, os fatores psicológicos provocam direta ou indiretamente o aumento do tônus muscular ${ }^{2}$.

Turk et al. ${ }^{3}$ relataram que distúrbios psicológicos como depressão e ansiedade são considerados freqüentemente como associados às síndromes de dor orofacial, porém explicam que as pesquisas a respeito do papel das características psicológicas na DTM têm sido controversas.

Para Dworkin ${ }^{4}$, condições de dor crônica, entre as quais se incluem as DTMs, são conhecidas por envolverem fatores psicológicos, comportamentais e sociais em conjunto com a patologia física. O autor considera que estresse, depressão, incapacidade e doenças de disfunção comportamental são aspectos críticos do perfil dos pacientes com DTM. No entanto, apenas mínima atenção tem sido dada para a classificação desses fatores comportamentais como auxiliares no conhecimento mais detalhado da condição ou para guiar o tratamento clínico e avaliação dos resultados físicos e psicossociais a longo prazo.

Em trabalho realizado por Serralta ${ }^{5}$, verificou-se que pacientes com DTM apresentam queixas mais freqüentes de ansiedade, depressão e estresse, e que pacientes bruxômanos, apresentam níveis significativamente mais altos de ansiedade-traço, depressão e sentimentos auto-destrutivos.

Com base na literatura consultada, parece existir uma associação entre fatores psicossocias, tais como a ansiedade, e disfunções da articulação temporomandibular. Portanto, este estudo teve como objetivo avaliar a presença de estado e traço de personalidade ansiosa em indivíduos com DTM e assintomáticos.

\section{MATERIAL E MÉTODOS}

O desenho desta pesquisa consiste em um estudo transversal, de caráter qualitativo e quantitativo. O estudo foi desenvolvido no Serviço de Atendimento Fonoaudiológico e Serviço de Odontologia da Universidade Federal de Santa Maria (UFSM). Após aprovação do projeto pelo Comitê de Ética em pesquisa da Universidade Federal de Santa Maria (016848/2005), todos os voluntários foram informados a respeito dos objetivos e procedimentos utilizados na pesquisa e assinaram um termo de consentimento livre e esclarecido, conforme resolução CSN 196/ 96.

Foram estudados 35 voluntários, com idades entre 19 e 53 anos, distribuídos em 2 grupos: grupo DTM e grupo assintomático.

Grupo DTM: 20 sujeitos selecionados entre indivíduos que procuraram o Serviço de Odontologia da Universidade Federal de
Santa Maria com sintomas de dor orofacial ou na articulação temporomandibular, com DTM confirmada pelo diagnóstico odontológico. Dezenove sujeitos eram do gênero feminino e um do masculino, com idades entre 20 a 46 anos, e média aproximada de 27 anos (DP= 7,05).

Foram excluídos do estudo indivíduos com histórico de traumas ortopédicos na região facial, doenças reumáticas, pacientes em tratamento odontológico com uso de placa (miorrelaxante ou reposicionadora) com remissão de sintomas ou em tratamento fisioterápico ou medicamentoso específico.

Grupo Assintomático: 15 sujeitos classificados através do Índice Anamnésico de Fonseca quanto ao grau de disfunção como sem disfunção ou com disfunção leve (assintomáticos). Este índice foi utilizado com a finalidade de triagem dos sujeitos assintomáticos por ser de fácil e rápida aplicação. Os voluntários eram todos do gênero feminino e possuíam idades entre 19 e 53 anos e média aproximada de 24 anos ( $\mathrm{DP}=8,24)$.

Após o diagnóstico odontológico de DTM, os indivíduos com disfunção foram submetidos ainda à avaliação pelo Índice Anamnésico e Clínico de Disfunção e Estado Oclusal $^{7}$, que inclui: (1) Índice de Disfunção Clínica, que avalia a amplitude e presença de desvio no movimento mandibular, presença de sons na ATM (verificada através da auscultação e palpação articular), sensibilidade à palpação dos músculos mastigatórios e da ATM; (2) Índice de Mobilidade articular, verificando a medida das amplitudes máximas de movimento mandibular em abertura, lateralidade direita e esquerda e protrusão (medidas realizadas por meio de paquímetro); (3) Índice Anamnésico de Disfunção, que avalia sintomas relatados pelos pacientes tais como sons na ATM, sensação de fadiga na mandíbula, sensibilidade ou rigidez na mandíbula ao acordar ou em sua abertura, dificuldade para abrir a boca em toda sua amplitude, travamento, luxação, dor ao movimento, dor na ATM ou músculos mastigatórios; (4) Índice de Estado Oclusal (avaliado por dentista especializado na área), verificando o número de dentes e sua oclusão, bem como a presença de interferências articulares ou oclusais. Os indivíduos previamente classificados como sem DTM ou assintomáticos no Índice de Fonseca não foram submetidos a esta avaliação, visto que o referido índice demonstrou correlação com o Índice de Helkimo em estudos anteriores ${ }^{8}$.

Para avaliação da presença do estado e traço de ansiedade em indivíduos com DTM e assintomáticos foi utilizado o Inventário de Ansiedade Traço-Estado (IDATE) ${ }^{9}$. Este instrumento constitui-se de um questionário auto-aplicado composto de duas sub-escalas distintas usadas para avaliar o estado e o traço de ansiedade. A sub-escala Ansiedade-Estado avalia como o indivíduo sente-se em um momento particular no tempo e a sub-escala Ansiedade-Traço revela como o ele geralmente se sente. As duas sub-escalas são pontuadas separadamente, sendo o escore mínimo e máximo de 20 e 80 para cada uma delas ${ }^{10}$. O Inventário de Ansiedade Traço-Estado 
foi administrado por um fisioterapeuta, previamente treinado por professor do departamento de psicologia.

Após a coleta dos dados, os mesmos foram submetidos à análise estatística descritiva, com cálculo da média aritmética e desvio padrão dos valores obtidos nos referidos grupos para todas as variáveis. Utilizou-se o teste "Kruskal-Wallis" para variáveis não paramétricas, com o objetivo de investigar se os grupos diferiam entre si quanto ao estado e traço de ansiedade. Para as variáveis em que houve diferença significativa, foram verificadas as correlações (Análise de Correlação de Pearson) com os escores quantitativos do Índice de Helkimo (Índice de Disfunção Clinica, Índice de Mobilidade Articular e Índice de Estado Oclusal - o Índice Anmnésico não pode ser correlacionado por ser um índice descritivo), aplicado no grupo com DTM. Para a análise estatística foi utilizado o programa Statiscal Analisys System (SAS versão 8.02).

A análise e interpretação dos dados coletados pelo inventário IDATE foi realizada com auxílio de um professor do departamento de psicologia da UFSM.

\section{RESULTADOS}

Inicialmente, serão apresentados os resultados relacionados ao grau de disfunção, obtidos pelo Índice de Helkimo $^{7}$ que descrevem o perfil dos participantes com DTM em relação à disfunção.

Tabela 1 - Distribuição relativa dos indivíduos com DTM quanto ao Índice Anamnésico e Clínico de Disfunção e Estado Oclusal de Helkimo (1974)

\begin{tabular}{lcccc}
\hline Grau de Disfunção & $\begin{array}{c}\text { Índice Disfunção } \\
\text { Clinica(\%) }\end{array}$ & $\begin{array}{c}\text { Índice Mobilidade } \\
\text { Articular(\%) }\end{array}$ & $\begin{array}{c}\text { Índice Anamnésico } \\
\text { Disfunção(\%) }\end{array}$ & $\begin{array}{c}\text { Índice Estado } \\
\text { Oclusal(\%) }\end{array}$ \\
\hline Normal ou Sem Disfunção & 0 & 30 & 0 & 10 \\
Disfunção Leve & 40 & 65 & 40 & $*$ \\
Disfunção Moderada & 45 & $*$ & $*$ & 65 \\
Disfunção Severa & 15 & 5 & 60 & 25 \\
\hline Total & 100 & 100 & 100 & 100 \\
\hline
\end{tabular}

*Esta classificação não consta no referido Índice.

A partir da Tabela II, pode-se observar que indivíduos com DTM apresentaram escores médios significativamente maiores tanto em relação ao estado de ansiedade $(43,3)$ quanto ao traço de personalidade ansiosa $(48,1)$, quando comparados aos participantes do grupo assintomático (35,7 e 36,73 respectivamente).

Tabela II - Escores de estado e traço de ansiedade (IDATE) de portadores de DTM e indivíduos assintomáticos

\begin{tabular}{lcccccccc}
\hline & \multicolumn{7}{c}{ Indivíduos com DTM } & \multicolumn{5}{c}{ Indivíduos Assintomáticos } \\
\hline & $\mathrm{x}$ & $\mathrm{dp}$ & $\mathrm{N}$ & \multicolumn{2}{c}{$\mathrm{d}$} & $\mathrm{dp}$ & $\mathrm{n}$ & $\mathrm{p}$ \\
Estado de Ansiedade & 43,3 & 10,66 & 20 & 35,07 & 5,93 & 15 & $0,0079^{*}$ \\
Traço de Ansiedade & 48,1 & 11,21 & 20 & & 36,73 & 4,95 & 15 & $0,0028^{*}$ \\
\hline
\end{tabular}

As análises de correlação de Pearson realizadas para as variáveis estado e traço de ansiedade e os escores quantitativos do Índice de Helkimo (Índice de Disfunção Clinica, Índice de Mobilidade Articular e Índice de Estado Oclusal) do grupo DTM, não revelaram correlação significativa entre as variáveis $(\mathrm{p}<0,05)$.

\section{DISCUSSÃO}

Neste estudo, foram utilizados os Índices de Fonseca e Helkimo, sendo que o primeiro teve como finalidade classificar os voluntários em indivíduos com DTM e assintomáticos e o segundo para o exame detalhado da articulação, oclusão e músculos mastigatórios dos indivíduos identificados com DTM. Estudos prévios utilizaram estes instrumentos para a identificação de fatores etiológicos e o acometimento multifatorial de pacientes com DTM e demonstraram correlação entre estes índices ${ }^{8}$.

A tabela I apresenta a distribuição relativa dos indivíduos com DTM quanto ao Índice Anamnésico e Clínico de Disfunção e Estado Oclusal de Helkimo, que descreve o perfil dos indivíduos quanto a sua disfunção. Analisando-se o conjunto destes resultados, constata-se que, embora a maior parte dos indivíduos tenham sido classificados como sem disfunção, disfunções leve e/ou moderada nos índices de disfunção clínica (85\%), mobilidade articular (95\%) e oclusal (75\%), não é o 
que se observa quanto ao índice anamnésico de disfunção, que identificou a presença de sinais e sintomas referidos de DTM como severos na maioria dos indivíduos com disfunção (60\%). O fato de estes indivíduos apresentarem-se ao exame, clinicamente melhores do que se descrevem ou se reconhecem, pode nos levar a pensar que existe um fator psicológico importante agindo na intensificação da dor e sintomas percebidos. No entanto, a correlação entre estes fatores não pôde ser estabelecida, pois os dados originados pelo Índice Anamnésico de Disfunção são qualitativos, enquanto os Ìndices de Disfunção Clinica, Mobilidade e Estado Oclusal geram dados quantitativos.

Rugh e Dahlström ${ }^{11}$ expuseram afirmações concordantes com este resultado, explicando que fatores emocionais, tais como a ansiedade e a depressão, influenciam as DTMs, tanto na percepção de dor pelo paciente ou sua vontade de tolerar a dor, como em relação ao sucesso do tratamento realizado.

Concordando com estas considerações, Visscher et al ${ }^{12}$, refere que as alterações psicológicas estão relacionadas com a intensidade da dor, ou seja, distúrbios psicológicos são mais comuns em pacientes com dor muscular crônica.

Kino et al ${ }^{13}$ também avaliaram aspectos emocionais de indivíduos com DTM utilizando o HADS (Hospital Anxiety and Depression Scale) e observaram que, mesmo não havendo diferença significativa nos níveis de ansiedade entre os subgrupos de DTM (dor miofascial, deslocamento de disco e artralgia), existe uma relação entre dor e ansiedade, pois em um grupo de pacientes com dor foi observado maior número de pacientes ansiosos comparado a um grupo de pacientes sem dor. Este é um aspecto importante que deve ser melhor investigado em estudos posteriores.

Para a padronização do diagnóstico de DTM, foi desenvolvido por Dworkin \& LeResche ${ }^{4}$ um método de coleta de dados denoninado Research Diagnostic Criteria for Temporomandibular Disorders (RDC/TMD). O instrumento constitui-se de dois eixos, Eixo I para o diagnóstico físico das desordens musculares e/ou articulares e o Eixo II que avalia fatores comportamentais, psicológicos e psicossociais. Este método permite uma avaliação mais abrangente, que contempla não só os aspectos clínicos, mas também os fatores emocionais que podem estar presentes nesta disfunção. Neste estudo, não foi utilizado este método diagnóstico, o que constituiu um fator limitante na avaliação dos pacientes, principalmente para a diferenciação entre os tipos de disfunção. O RDC permite a classificação das DTMs em 3 subgrupos: musculares; deslocamentos de disco e, artralgia, artrite e artrose da articulação temporomandibular (ATM).

Novos estudos ${ }^{14}$ vêm analisando as variações de respostas fisiológicas, físicas e comportamentais ao longo das fases menstruais, já que o comportamento perceptivo, controle motor e respostas dolorosas podem ser influenciadas por variações dos hormônios sexuais femininos. Este aspecto, no entanto, não foi contemplado na avaliação dos sujeitos deste estudo e constitui-se em fator cautelar na análise dos dados, já que a amostra foi composta predominantemente pelo gênero feminino.
Os resultados apresentados na tabela II demonstram que houve diferença estatisticamente significante entre os grupos pesquisados, sendo os escores de estado e traço de ansiedade maiores entre indivíduos com DTM em relação aos assintomáticos, especialmente quanto a traço de ansiedade. No entanto, considerando que o escore mínimo possível é de 20 e o máximo 80 , é importante observar que foram encontrados, em média, escores de ansiedade moderados nos indivíduos avaliados.

Não houve correlação significativa entre as variáveis estado e traço de ansiedade e os escores dos Índices de Disfunção Clinica, Mobilidade Articular e Estado Oclusal, no grupo pesquisado. Um fator limitante para a correlação destas variáveis foi o fato de o Índice de Helkimo ser constituído de 4 índices que não podem ser sintetizados em um único escore ou valor quantitativo para cada individuo, de modo que a comparação dos resultados inter-grupos e intra-grupo fica comprometida. Assim, mesmo havendo diferença estatisticamente significativa entre os escores de Estado/traço ansiedade nos indivíduos com DTM e assintomáticos, o fator causal disto não foi estabelecido pela falta de correlação entre as variáveis no presente estudo

Anselmo ${ }^{15}$ utilizou o QSG (questionário de saúde geral) e revisou estudos que utilizaram questionários psicológicos em pacientes com DTM como: DSM-II, Minnesotta Multiphasic Personality Inventory, IDATE, Hamilton Anxiety Rating Scale. A autora comparou 100 indivíduos com DTM e 100 indivíduos do grupo controle, e observou escores mais elevados de problemas psicológicos nos primeiros e em sujeitos do sexo feminino. Embora tendo utilizado um instrumento diferente, os resultados encontrados são concordantes com os da presente pesquisa, já que o QSG detecta doenças psiquiátricas não severas (não psicóticas) e se propõe a medir o bem-estar psicológico, incluindo fatores como ansiedade e depressão.

Em contrapartida, Martinez ${ }^{16}$ utilizou o inventário IDATE para investigar as diferenças entre pacientes bruxômanos e um grupo controle de estudantes universitários e obteve resultados discordantes com os descritos neste estudo. Comparando-se os escores nas escalas de ansiedade traço/estado, o autor não observou diferença significante entre os grupos, porém revelou-se uma tendência oposta à prevista, isto é, os controles apresentavam escores maiores nas escalas de ansiedade. Essa tendência foi atribuída ao fato do inventário (IDATE) ser de auto-aplicativo, uma vez que as pessoas tendem a não reconhecer os sentimentos e emoções relacionadas com reações psicossomáticas (ex. bruxismo).

Também Pallegama et al ${ }^{10}$ utilizaram o instrumento de Spielberger (IDATE), em pacientes com DTM miogênica com e sem dor cervical associada e um grupo controle, e observaram que os grupos de pacientes exibiram níveis significativamente mais elevados de traço de ansiedade que o grupo controle. 
Quanto ao estado de ansiedade, apenas o grupo de pacientes com DTM e dor cervical associada apresentou níveis significativamente maiores que o grupo controle. Estes autores comentam que o IDATE tem sido um instrumento amplamente usado na pesquisa clínica e com alto nível de confiabilidade.

Da mesma forma, corroborando os resultados aqui encontrados, Serralta ${ }^{17}$ encontrou correlações significativas entre a maioria dos sintomas de DTM e queixa psicológicas de ansiedade, depressão e estresse.

Fortes evidências demonstram que pacientes com DTM são mais ansiosos e/ou depressivos que indivíduos assintomáticos, sendo que os sintomas da DTM iniciam durante períodos de estresse psicológico (ansiedade) e exacerbam durante situações estressantes. Isto constitui um ciclo vicioso onde o estresse emocional causa alterações funcionais nos sistemas opióide e serotoninérgico, causando sensação de dor e hiperatividade muscular, as quais contribuem para elevar mais ainda o nível de estresse $^{18}$.

Concordando com estas considerações, Bove et al ${ }^{19}$, num estudo com 150 pacientes com DTM, verificaram que a maioria (87\%) sentia-se ansiosa. Os autores acrescentam que a depressão é o estado emocional mais comum associado à dor crônica, porém a ansiedade também pode ser associada à DTM, principalmente em períodos de agudização da disfunção.

Cabe considerar ainda, que a ansiedade é um dos fatores que pode levar ao uso excessivo de músculos acessórios da respiração, determinando um padrão ventilatório torácico superior. Este padrão ventilatório provoca contração dos músculos cervicais que se dissipa para a face, causando hipertonia dos músculos mastigatórios, dor muscular e alterações na articulação têmporomandibular $^{20}$. O predomínio do padrão ventilatório apical em pacientes com DTM foi observado por Pasinato, Corrêa \& Peroni ${ }^{21}$, enquanto indivíduos assintomáticos apresentaram padrão diafragmático. Assim, a relação entre ansiedade e DTM pode estar associada com a respiração e tensões musculares associadas, que fixam alterações posturais potencialmente causadoras de dor craniofacial.

Finalmente, LeResche et al apud Turk ${ }^{3}$, compararam os perfis psicológicos de grupos de pacientes com disfunção de dor miofascial, desarranjo interno e doença articular degenerativa, e constataram através de critérios diagnósticos, que a disfunção de dor miofascial estava associada com níveis mais altos de ansiedade, depressão e somatização que os grupos com desarranjo interno e doença articular degenerativa. Assim, para estudos futuros, recomenda-se a diferenciação das DTMs em subgrupos (miogênica, discogênica e artrogênica) para avaliação de seus respectivos escores de ansiedade, o que no presente trabalho não foi realizado devido à limitação inerente ao número de sujeitos e instrumento utilizado para avaliação da DTM.

\section{CONCLUSÃO}

A partir da análise dos resultados encontrados nesta pesquisa e considerando o objetivo ao qual ela se propôs, pode-se concluir, que estado e traço de personalidade ansiosa estiveram presentes em indivíduos com DTM, e nestes aspectos, os mesmos apresentaram diferença estatisticamente significante quando comparados aos assintomáticos para esta disfunção.

Entende-se, portanto que, estado e traço de ansiedade podem contribuir para a gênese e perpetuação das disfunções temporomandibulares. Assim, o sucesso terapêutico nas DTMs requer uma abordagem multidisciplinar (odontólogo, fisioterapeuta, psicólogo, médico psiquiatra, etc), onde os diversos aspectos etiológicos responsáveis por sua gênese possam ser abordados.

\section{REFERÊNCIAS}

1. Manfredi APS, Bortolleto PPB, Da Silva AA, Araújo IEM, Araújo S, Vendite LL. Environmental stress and temporomandibular disorder (TMD) among members of a public university in Brazil. Braz J Oral Sci. 2006; 5(18):1074-78.

2. Steenks MH, de Wijer A. Disfunções da articulação têmporomandibular do ponto de vista da fisioterapia e da odontologia. São Paulo: Ed Santos, 1996.

3. Turk DC, Rudy TE, Zaki H S. Avaliação multiaxial e classificação de pacientes com dor de desordem temporomandibular. In: Dor orofacial e desordens temporomandibulares. São Paulo: Ed. Santos; 2003.

4. Dworkin SF, LeResche L. Research diagnostic criteria for temporomandibular disorders: review, criteria, examinations and specifications, critique. J Craniomandib Disord. 1992;6:301-355. 5. Serralta FB, Martins EA, Ávila JF. Adaptação de um instrumento de triagem para problemas psicológicos em pacientes com disfunção craniomandibular e dor orofacial. JBA. 2001;1(1):8085.

6. Fonseca DM. Disfunção craniomandibular (DCM): diagnóstico pela anamnese [Dissertação]. Bauru: FOB-USP; 1994.

7. Helkimo M. Studies on function and dysfunction of the masticatory system - II Index for anamnesic and clinical dysfunction and oclusal state. Swet Dent J. 1974;67(2):101121.

8. Oliveira AS. Caracterização multifatorial de uma população de portadores de desordens temporomandibulares [tese]. Piracicaba: FOP-UNICAMP; 2002.

9. Spielberger CD, Gorsush RL, Lushene RE. Inventário de Ansiedade Traço-Estado. Manual. Rio de Janeiro: CEPA; 1979. 
10. Pallegama RW, Ranasinghe AW, Weerasinghe VS, Sitheeque MAM. Anxiety and personality traits in patients with muscle related temporomandibular disorders. J Oral Rehab. 2005;32: 701-707.

11. Rugh, JD, Dahlström, L. Mecanismos psicológicos e comportamentais. In: Disfunção da articulação têmporo-mandibular e dos músculos da mastigação. São Paulo: Ed. Santos, 2000.

12. Visscher CM, Lobbezoo F, De Boer W, Van der Meulen M, Naeije M. Psychological distress in chronic craniomandibular and cervical spinal pain patients. Eur J Oral Sci. 2001;109:165-171.

13. Kino K, Sugisaki M, Haketa T, Amemori Y et al. The comparison between pains, difficulties in function, and associating factors of patients in subtypes of temporomandibular disorders. J Oral Rehab. $2005 ; 32: 315-325$.

14. Barbosa MB. Avaliação dos limiares sensitivo, motor e doloroso nas diferentes fases do ciclo menstrual. [dissertação]. Piracicaba:UNIMEP;2006. Disponível em: http://www.unimep.br/ phpg/bibdig/.

15. Anselmo SM. Estudo da correlação dos distúrbios psiquiátricos menores e as desordens temporomandibulares [dissertação].
Piracicaba: FOP-UNICAMP; 2003.

16. Martinez TM. Ansiedade e raiva em bruxômanos e nãobruxômanos. Psicologia: Reflexão e Crítica. 1996;8:301-312.

17. Serralta FB, Martins EA, Chaves KB. DTM e Problemas psicológicos em estudantes de odontologia. Jornal Multidisciplinar da Dor Craniofacial 2003;3(12):312-315.

18. Gameiro GH, Andrade AS, Nouer DF, Veiga MCFA. How may stressful experiences contribute to the development of temporomandibular disorders? Clin Oral Invest. 2006;10:261268.

19. Bove SRK, Guimarães AS, Smith RL. Caracterização dos pacientes de um ambulatório de disfunção têmporo-mandibular e dor orofacial. Rev Latino-am Enfermagem 2005;13(5):68691.

20. Corrêa ECR, Bérzin F. Temporomandibular disorder and dysfunctional breathing. Braz J Oral Sci. 2004;3(10):498-502.

21. Pasinato F, Corrêa ECR, Peroni ABF. Avaliação da mecânica ventilatória em indivíduos com disfunção têmporo-mandibular e assintomáticos. Rev Bras Fisioter. 2006;10(3):285-289.

Agradecimentos: Ao Prof. Dr. Claudio Figueiró da Universidade Federal de Santa Maria, responsável pela avaliação odontológica dos participantes do estudo e à Prof ${ }^{a}$. Dra. Cláudia Giacomoni do Departamento de Psicologia da Universidade Federal de Santa Maria pelo auxílio na análise e interpretação do Inventário de Ansiedade.

Endereço para Correspondência:

Fernanda Pasinato: R. Dr. Bozano, 696, apto 303

Cep 97015-000, Santa Maria- RS

Email: fepas.fisio@yahoo.com.br.

Telefones: res: (55) 3217-3245; prof: (55) 3025-2184 ou (55) 81179089. 


\title{
APICIFICAÇÃO DE INCISIVOS CENTRAIS SUPERIORES USANDO HIDRÓXIDO DE
} CÁLCIO: RELATO DE CASO

\section{Central incisor apexification using calcium hydroxide: a case report}

\author{
Clacir Londero Zenknerl, Claudia Medianeira Londero Pagliarin ${ }^{2}$ e Fernando Branco Barletta ${ }^{3}$
}

\begin{abstract}
RESUMO
Quando ocorre a necrose pulpar em dentes permanentes com ápice incompleto, há necessidade de induzir o desenvolvimento radicular com a finalidade de criar uma barreira de tecido mineralizado no terço apical facilitando posteriormente a obturação definitiva do canal radicular. Esta técnica é denominada de apicificação. O objetivo deste trabalho foi descrever um tratamento bem sucedido de apicificação nos dentes 11 e 21 que sofreram necrose pulpar após a ocorrência de um trauma.

Palavras-chave: rizogênese incompleta, hidróxido de cálcio, apicificação.

SUMMARY

When there is the pulp necrosis in permanent teeth with open root apex, there is the need to induce the root development aiming to create a barrier of mineralized tissue at the apical third, making it easy, subsequently, definitive filling of the root canal. This technique is called apexification. The following work aimed to describe a successful treatment with calcium hydroxide at the 11 and 21 teeth, which suffered pulp necrosis after a trauma.

Key-words: incomplete rhizogenesis, calcium hidroxide, apexification.
\end{abstract}

\section{INTRODUÇÃO E REVISÃO DA LITERATURA}

Uma das possíveis conseqüências do trauma em dentes permanentes jovens é a necrose pulpar. Se o dente tiver rizogênese imcompleta, a técnica do tratamento endodôntico deve ser realizada de maneira a promover o desenvolvimento radicular as expensas da bainha epitelial de Hertwig quando esta possuir células viáveis ( apicigênese), ou através do emprego do hidróxido de cálcio para que ocorra a deposição de tecido duro na região apical( apicificação) (Heithersay,1975).

A apicificação "induz uma barreira de tecido duro em uma raiz com ápice aberto ou a continuação do desenvolvimento apical de uma raiz incompleta em dentes com polpa necrótica" (American Association of Endodontists, 2003).

Diferentes técnicas de apicificação têm sido propostas, sendo a mais comum a que usa o hidróxido de cálcio por um período indeterminado de tempo (Frank, 1966; Estrela et al. 2001).

O hidróxido de cálcio tem sido indicado para apicificação, pois o seu $\mathrm{pH}$ alcalino e sua presença física dentro do canal apresentam um potente efeito antibacteriano, inibindo a atividade osteoclástica e prevenindo a entrada de exudato e tecido de granulação. Esta situação propicia a formação de tecido mineralizado junto ao ápice radicular (Cvek, 1974). Segundo Felippe (2005), pastas de hidróxido de cálcio têm sido usadas para obter a desinfecção do canal e a indução da formação de uma barreira de tecido calcificado na região apical de dentes que se apresentam despolpados e com rizogênese incompleta.

O uso do hidróxido de cálcio foi primeiro introduzido por Kaiser em 1964 e popularizado por Frank em 1966 que propôs misturar este material com PMCC para induzir a formação de uma barreira de tecido calcificado no ápice. $\mathrm{O}$ hidróxido de cálcio pode ser associado a várias outras substâncias, com a finalidade de potencializar suas propriedades, e com os mais variados veículos: viscosos ou não. Ao longo de muitos anos diversas associações foram testadas, no entanto sem evidências de que um produto seja mais vantajoso que outro (Andreasen, 1984; Leonardo et al, 1993).

No presente trabalho, foi utilizada como medicação intracanal a pasta de hidróxido de cálcio com PMCC (Calen SS White).

${ }^{1}$ Cirurgiã-Dentista da Universidade Federal de Santa Maria (UFSM).

${ }^{2}$ Professora Assistente do Departamento de Estomatologia do Curso de Odontologia da UFSM

${ }^{3}$ Professor, Departamento de endodontia da Universidade Luterana do Brasil, Canoas, RS, Brasil. 
RELATO DO CASO

O menino O.S.A. (8 anos), após várias voltas ao redor de um pilar, soltou-se caindo e batendo com a boca no chão. Os incisivos centrais superiores sofreram fraturas coronárias que foram restauradas, e após um período de mais ou menos 2 anos, através do exame clínico e radiográfico foi detectada a necrose e rizogênese incompleta de ambos os dentes (Figura 1). O tratamento proposto foi a apicificação com o uso do hidróxido de cálcio (Calen- SS White).

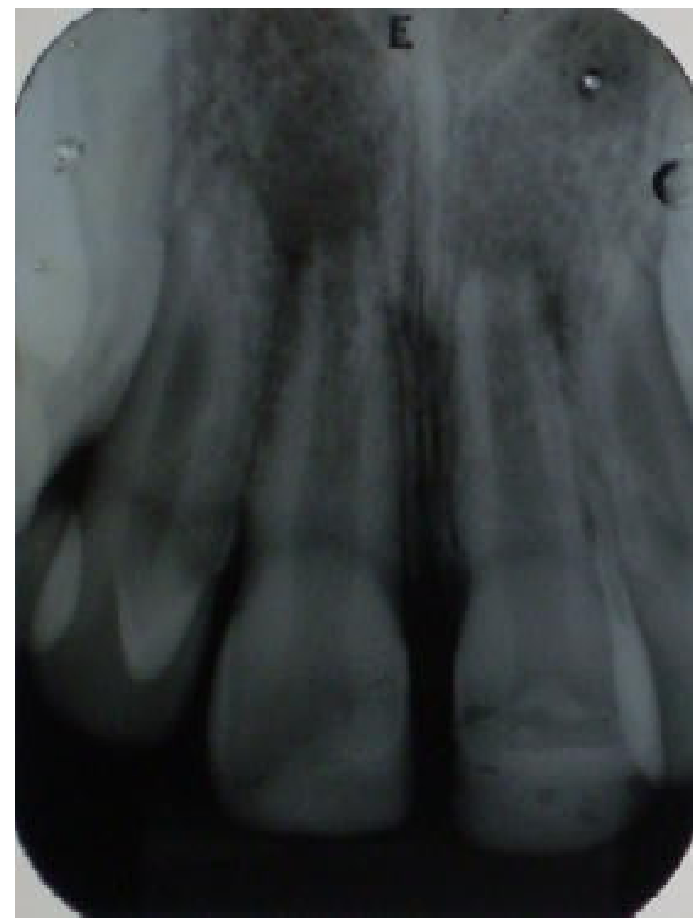

Figura 1 - Radiografia inicial, mostrando os dentes 11 e 21 com ápice incompletamente formado.

Os dentes foram isolados com dique de borracha, tomandose o cuidado de colocar os grampos nos dentes posteriores devido a pouca indicação de uso de grampos nos referidos dentes (fraturas coronárias).

A seguir foi feita a abertura coronária com broca esférica de tamanho compatível com a câmara pulpar complementada com o uso da broca Endo Z (Maillefer). Posteriormente realizou-se neutralização do conteúdo séptico-tóxico com limas tipo $\mathrm{K}$ e hipoclorito de sódio a $2,5 \%$, cuidando para não atingir os tecidos periapicais. A odontometria foi realizada com a lima calibrada no comprimento de trabalho provisório que foi obtido com base na radiografia prévia (Figura 2). Os canais foram instrumentados até a lima número 80, cuidando para não desgastar demasiadamente suas paredes, sempre irrigando abundantemente com hipoclorito de sódio a 2,5\%. Fez-se a remoção da smear layer com EDTA a $17 \%$ e irrigação final com hipoclorito de sódio. Os canais foram secos e preenchidos com a pasta de hidróxido de cálcio (Calen - SS
White) usando para isto broca lêntulo calibrada a $3 \mathrm{~mm}$ do comprimento de trabalho, para evitar o extravasamento da pasta. Após os dentes foram selados com ionômero de vidro (Vidrion R,SS White).
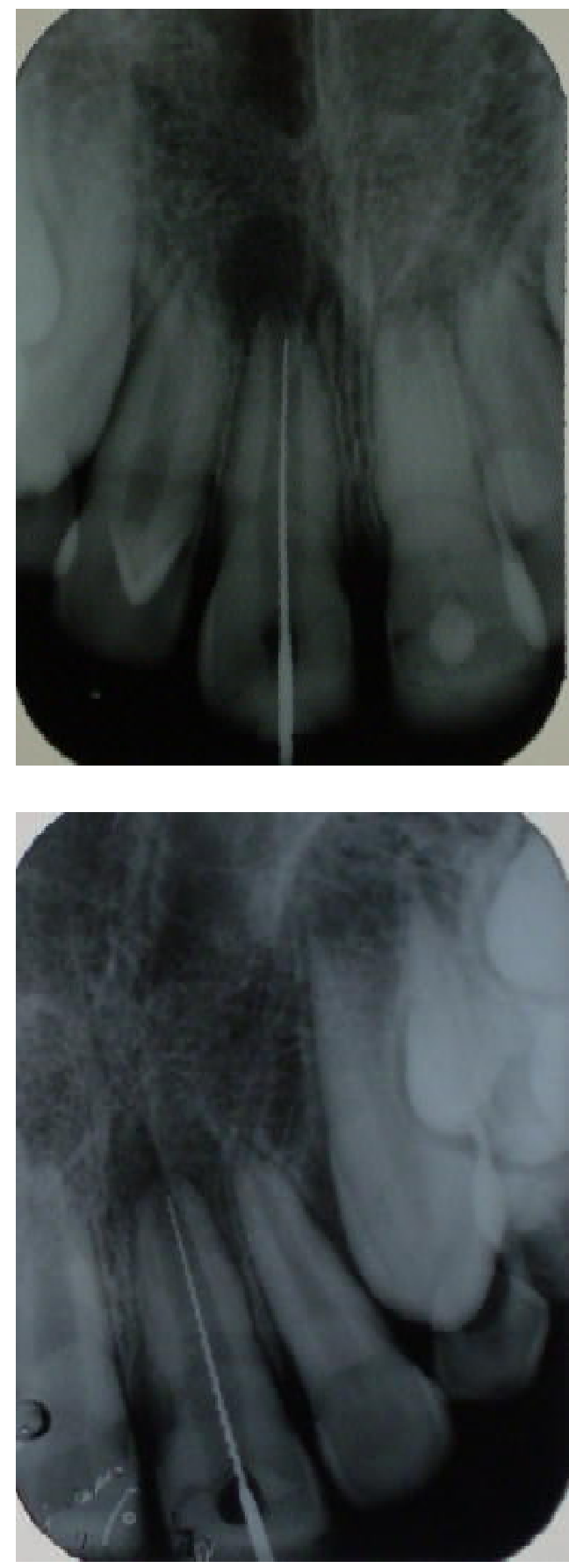

Figura 2 - Radiografias da odontometria.

A troca do hidróxido de cálcio foi realizada inicialmente em sete dias, pois os canais apresentavam intensa drenagem de exudato. Decorridos 30 dias foi feita nova troca do curativo e subsequentemente a cada três meses até a completa formação da barreira de tecido calcificado, detectada através do exame 
da barreira foi de 1 ano e 4 meses. Os dentes foram obturados utilizando-se a técnica dos cones moldados e condensação lateral (Figura 3, 4 e 5).

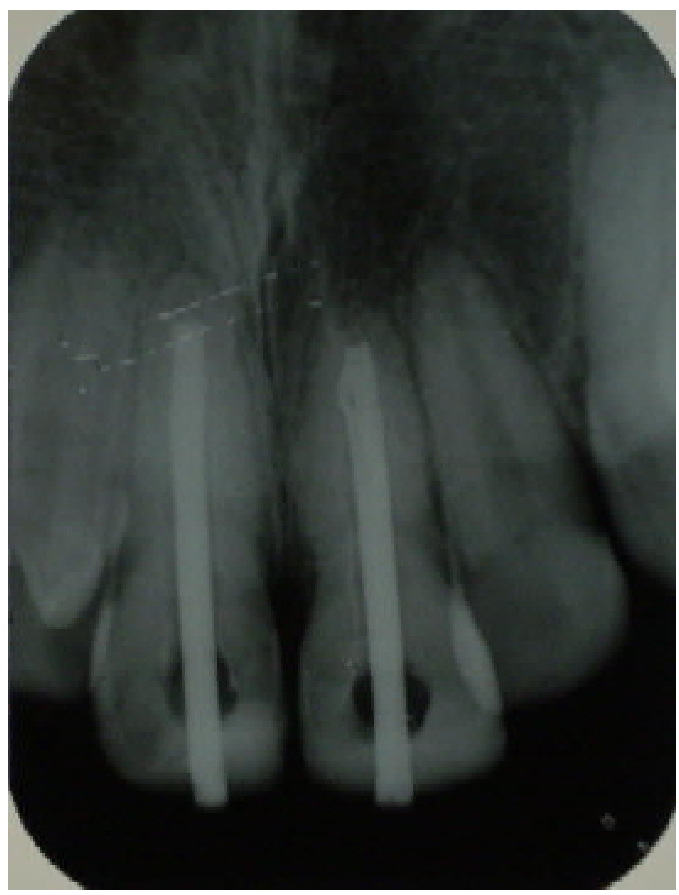

Figura 3 - Radiografia mostrando a confecção dos cones principais moldados.

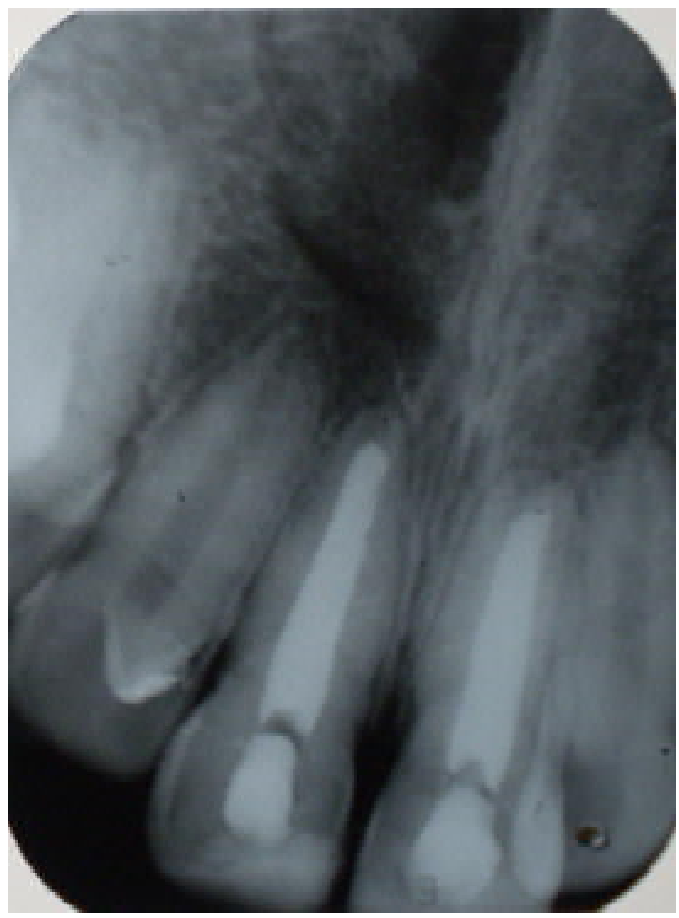

Figura 4 - Radiografia da obturação concluída.

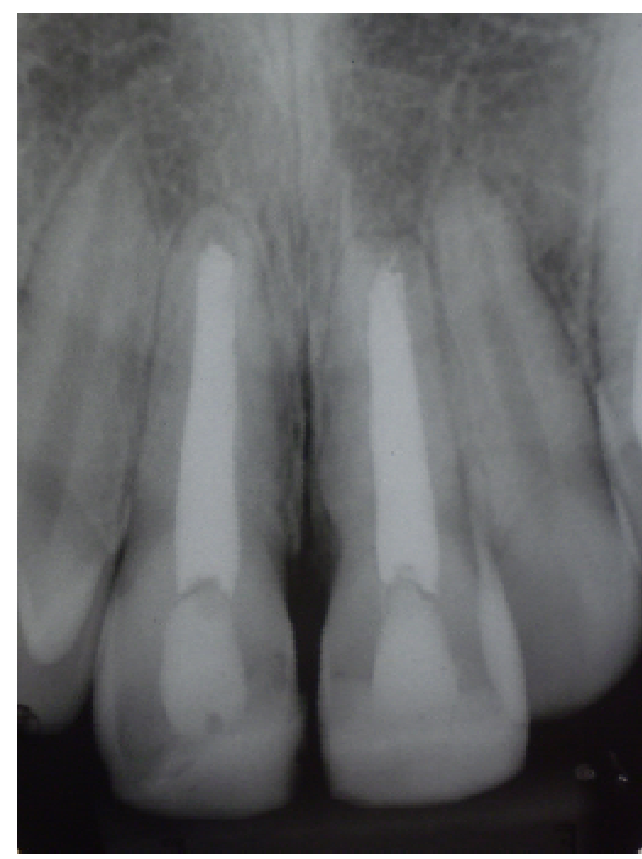

Figura 5 - Com um ano de acompanhamento.

\section{DISCUSSÃO}

Traumatismos dentários são freqüentes em crianças, principalmente na faixa etária entre oito e onze anos, onde em dentes com rizogênese incompleta o tratamento endodôntico deve ser conduzido de forma distinta para haver condição da obturação do canal radicular, no entanto é discutível entre profissionais que exercem a especialidade, em relação as trocas de hidróxido de cálcio e o seu tempo de permanência no interior do canal radicular.

Concordamos com Felippe,2005; Soares,2008 que dentes com rizogênse incompleta e necrose pulpar necessitam por um período de tempo do emprego de uma medicação intra canal para que ocorra a deposição de tecido duro na região apical, motivo desta discussão.

Dentre os materiais indicados para induzir a formação da barreira de tecido duro, o hidróxido de cálcio tem tido uma considerável aceitação (Rafter,2005; Chosack,1997; Soares,2008). Neste caso clínico optou-se pelo uso do hidróxido de cálcio associado ao PMCC (Calen - SS WHITE), a exemplo de vários estudos que mostram um alto nível de sucesso clínico com o uso desta associação (Frank,1966; Dylewski, 1971; Van Hassel, 1970).

Cvek (1974) salienta que a técnica designada "apicificação com hidróxido de cálcio" apresenta, em tratamento prolongado, um índice de sucesso de $96 \%$, devido suas propriedades bactericidas, de indução da mineralização e compatibilidade 
biológica, sendo corroborada por Rafter (2005), que em um estudo de revisão, concluiu que apicificação com hidróxido de cálcio é a técnica mais empregada para o tratamento de dentes com ápices imaturos, e que o índice de sucesso é alto.

Com ralação à freqüência da troca do hidróxido de cálcio, neste caso optou-se por fazer a primeira em sete dias (devido à dificuldade de secar os canais), a segunda após trinta dias e as demais em intervalos de três meses até a completa formação da barreira de tecido mineralizado (Mackie, 1998).

Não existe um consenso entre os autores sobre qual é o melhor intervalo de tempo para fazer a troca do $\mathrm{CaOH}$, para induzir o fechamento apical e a normalidade dos tecidos periapicais (Sheehy, 1997). Alguns autores sugerem que a troca seja feita inicialmente em um mês e subsequentemente a cada intervalo de três meses (Mackie, 1998), Alguns autores acreditam que uma única aplicação da pasta de hidróxido de cálcio é suficiente para a formação da barreira (Chawla, 1986). Outra indicação é a de fazer a troca somente se o hidróxido de cálcio do terço apical do canal radicular for reabsorvido (Yates, 1988; Foreman, 1990).

Em seus estudos, Finucane \& Kinirons (1999) e Kinirons et al. (2001), reportam que o índice de formação da barreira foi diretamente proporcional à frequiência de renovação da pasta. No entanto, estes resultados diferem dos encontrados por Felippe M.C.S., 2005, que avaliou a influência da renovação da pasta de hidróxido de cálcio em apicificação de dentes de cães com formação radicular incompletae canais contaminados previamente e concluiu que a recolocação da pasta de hidróxido de cálcio não foi necessária para ocorrer a apicificação, no entanto, ela reduziu significativamente a intensidade do processo inflamatório. A renovação mensal da pasta reduziu significativamente a ocorrência da apicificação. Já, Chosack et al. (1997) compararam o efeito de uma simples aplicação da pasta de hidróxido de cálcio com aplicações mensais ou renovações em três meses e reportou que a quantia de tecido calcificado formado foi similar nos três grupos.

Embora existam divergências entre alguns autores quanto a fatores como intervalos de trocas, tempo médio para ocorrer a apicificação, é sabido que o hidróxido de cálcio é uma substância altamente eficiente e tem-se mostrado ao longo dos anos ser efetivo em casos de tratamento de dentes com rizogênese incompleta, motivo de nossa opção neste caso clínico, onde o resultado clínico após o controle radiográfico foi exitoso.

\section{REFERÊNCIAS}

1. American Association of Endodontists. Glossary of endodontic terms, $7^{\text {th }}$ edn. Chicago: American Association of Endodontists, 2003. 2. Andreasen JO. Traumatic injuries of the teeth. 3. ed. Copenhagen, Munksggard 1984. 478 p.
3. Binnie WH \& rowe ARH. A histological study of the periapical tissues of incompletely formed pulpless teeth filled with calcium hydroxide. J. dent. Res., 52 (5): 1110-6, Sept/Oct. 1973.

4. CVEK M. Treatment of non-vital permanent incisors with calcium hydroxide. Odont. Revy, 25 (30): 1-29, May 1974.

5. Dylewski JJ. Apical closure of non-vital teeth. Oral Surg 1971; 32:82-9.

6. Estrela C; Bammann LL, pimenta FC, Pecora J.D. Control of microorganisms in vitro by calcium hydroxide pastes. Intern Endod J 2001; 34:341

7. Frank A. Therapy for the divergent pulpless tooth by continued apical formation. J Am Dent Assoc 1966; 72:87-93. 8. Foreman PC, Barnes IE. A review of calcium hydroxide. International Endodontics Journal 1990; 23: 283-297.

9. Ghose LJ, Baghdady VS, Hikmat M. Apexification of immature apices of pulpless permanent anterior teeth with calcium hydroxide. Journal of Endodontics 1987; 13: 285-290.

10. Heithersay GS. Stimulation of root formation in incompletely developed pulpless teeth. Oral Surg., 29 (4): 620-30, Apr. 1970. 11. Holland R; Souza V; Tagliavini RL; Milanezi LA. Healing process of teeth with open apices: histological study. Bull. Tokyo dent. Coll. , 12 (4): 333-8, Nov. 1971.

12. Holland R; Souza V; Nery MJ; Mello W; Bernabe PFE. Root canal treatment with calcium hydroxide effect of an oily or a water soluble vehicle. Rev. Odont. UNESP, 12 (1/2): 1-6, 1983. 13. Kaiser HJ. Management of wide open apex canals with calcium hydroxide. Presented at the 21 st Annual Meeting of the American Association of Endodontists, Washington DC April 171964.

14. Kleier DJ, Barr ES. A study of endodontically apexified teeth. Endodontics and Dental Traumatology 1991; 7: 112117.

15. Leonardo MR; Silva LAB; Utrilla LS; Leonardo RT; Consolaro A. Effect of intracanal dressings on repair and apical bridging of teeth with incomplete root formation. Endodont. dent. Traumat., 9 (1): 25-30, Feb. 1993.

16. Mackie IC. Management and root canal treatment of nonvital immature permanent incisor teeth (UK National Clinical Guidelines in Paediatric Dentistry). International Journal of Paediatric Dentistry 1998; 8:289-293.

17. Maisto OA. Endodoncia. 2ed. Buenos Aires, Mundi, 1973.404 $\mathrm{p}$.

18. Rafter MA pexification: a rewiew. Dent Traumatol 2005; $21: 1-8$.

19. Soares IJ; Goldberg F. Endodontia: técnica e fundamentos. Porto Alegre: Artes Médicas Sul, 2001. p.251-262.

20. Soares J; Santos S; Cesar C; Silva P; Sá M; Silveira F; Nunes E. Calcium hydroxide induced apexification with apical root development: a clinical case report. International Endodontic Journal, 41, 710-719, 2008. 
21. Steiner JC, Dow PR, Cathey GM. Inducing root end closure of non-vital permanent teeth. J Dent Child. 1968; 35:47-54.
22. Steiner JC \& Van Hassel HJ. Experimental root apexification in primates. Oral Surg., 31 (3): 409-15, Mar. 1971.

Endereço para correspondência:

Rua: Av. Medianeira $n^{\circ} 1782$ Sala 01

Bairro: Centro

Santa Maria - RS

Fone: (55) 30268533

E-mail: clacirzenkner@smail.ufsm.br 
ESTUDO DA POSTURA CORPORAL EM CRIANCAS COM RESPIRAÇÃO PREDOMINANTEMENTE ORAL E ESCOLARES EM GERAL

Study of the body posture in children with predominant oral breathing and school-age children in general

\author{
Débora Bonesso Andriollo Basso ${ }^{1}$, Juliana Alves Souza ${ }^{2}$, Fernanda Pasinato ${ }^{3}$, \\ Eliane Castilhos Rodrigues Corrêa $a^{4}$, Ana Maria Toniolo da Silva
}

\begin{abstract}
RESUMO
Objetivo: avaliar a postura de respiradores predominantemente orais e comparar com achados, descritos na literatura, de escolares em geral. Métodos: a amostra foi composta por 30 escolares, respiradores orais, que foram submetidos à avaliação postural subjetiva com análise da simetria e do posicionamento das estruturas, nas vistas anterior, posterior e lateral. Os achados obtidos foram comparados aos descritos na literatura sobre a postura corporal de escolares em geral. Resultados: na vista anterior predominou a elevação do ombro direito, flexão de cotovelo e dedos. Na vista posterior, observou-se abdução e elevação das escápulas e rotação dos joelhos. E, na vista lateral, anteriorização da cabeça, protrusão e rotação interna de ombros. Na literatura revisada predominaram: semiflexão de joelhos, protrusão de ombros, hiperlordose lombar. Conclusão: o modo respiratório é essencial no equilíbrio postural de crianças em idade escolar. Algumas alterações são próprias do desenvolvimento postural normal, pois apareceram em ambos os grupos.
\end{abstract}

Palavras-chave: respiração bucal, postura, criança, avaliação.

\title{
SUMMARY
}

Objective: to evaluate the posture of children with predominant oral breathing and to compare these findings to the described ones in the literature related to the general school-age children. Methods: 30 school-age children with oral breathing were submitted to subjective postural evaluation, with analysis of the positioning symmetry of the structures in the anterior, posterior and lateral views. The obtained results were compared to those described in the literature related to the general school-age body posture. Results: in the anterior view, the elevation of the right shoulder, elbow and fingers flexion prevailed. In the posterior view, it was observed abduction and elevation of the scapulas and rotation of the knees. And, in the lateral view, it was observed forward head posture and protrusion and medial rotation of shoulders. In the literature findings it was observed semiflexion of the knees, shoulder protrusion and lumbar hyperlordosis. Conclusion: the breathing mode is essential for the postural balance of children in school- age. It was also evidenced that some alterations are peculiar of the normal postural development, once they were present in both groups.

Keywords: oral breathing, posture, children, evaluation.

\section{INTRODUÇ̃̃O}

A respiração nasal é fundamental, pois estimula os sensores da mucosa nasal, filtra, aquece e umidifica o ar antes desse chegar ao pulmão e cumprir sua função de hematose ${ }^{1}$. O fluxo e refluxo do ar pelas narinas produzem uma pressão que expande as vias aéreas e faz a aeração das cavidades pneumáticas paranasais. Assim, tal respiração é um dos principais fatores

Trabalho realizado no Serviço de Atendimento Fonoaudiológico da Universidade Federal de Santa Maria - RS (SAF - UFSM). ${ }^{1}$ Especialista em Fisioterapia Traumato-ortopédica e Desportiva pela Faculdade Internacional de Curitiba, mestranda do Programa de PósGraduação em Distúrbios da Comunicação Humana da UFSM, ; Funcionária Pública da Prefeitura Municipal de Bagé, RS - Brasil ${ }^{2}$ Especialista em Análise e Planejamento de Produtos e Processos Fisioterapêuticos pela UFSM, mestranda do Programa de Pós-Graduação em Distúrbios da Comunicação Humana da UFSM; Funcionária Pública do Hospital Universitário da UFSM.

${ }^{3}$ Especialista em Terapia Manual e Postural pela Cesumar, mestranda do Programa de Pós-Graduação em Distúrbios da Comunicação Humana da UFSM.

${ }^{4}$ Doutora em Biologia Buco-dental pela Faculdade de Odontologia de Piracicaba da Universidade Estadual de Campinas, Professora do Departamento de Fisioterapia e Reabilitação e do Programa de Pós-Graduação em Distúrbios da Comunicação Humana da UFSM.

${ }_{5}^{5}$ Doutora em Distúrbios da Comunicação Humana pela Universidade Federal de São Paulo, Professora do Departamento de Fonoaudiologia e do Programa de Pós-Graduação em Distúrbios da Comunicação Humana da UFSM. 
para o crescimento e desenvolvimento do terço médio da face, ou seja, favorece o crescimento craniofacial; além de proteger as vias aéreas inferiores ${ }^{2}$. Porém, quando algum fator impede a passagem de ar pela cavidade nasal, como no desvio de septo, na hipertrofia tonsilas palatinas e faringeanas devido a processos alérgicos (rinite, sinusite, bronquite), nas malformações entre outros, há uma alteração no modo respiratório, que passa a ser predominantemente oral $^{3,4}$.

A persistência da respiração oral durante a fase de crescimento da criança pode determinar uma série de alterações morfofuncionais que não se restringem à região craniofacial $^{5-9}$. Dentre essas estariam às mudanças dos órgãos fonoarticulatórios, como hipotrofia, hipotonia e hipofunção dos músculos elevadores da mandíbula, alteração do tônus dos lábios e bochechas, anteriorização da língua $^{10,11}$. Nas funções orais tem-se mastigação ineficiente, deglutição atípica, fala imprecisa e voz rouca ${ }^{12}$. Há diminuição no olfato e paladar, halitose, alteração no sono, sinusites freqüentes, baixo rendimento escolar e físico ${ }^{13}$. As alterações craniofaciais e dentárias mais evidentes são as dimensões faciais estreitas, hipodesenvolvimento da maxila, palato ogival, narinas estreitas, overjet, mordida aberta ou cruzada ${ }^{8,14,15,16}$. Ainda observam-se mudanças corporais tais como: cabeça mal posicionada, músculos abdominais flácidos, ombros protrusos, deformidades torácicas entre outras ${ }^{17-20}$. Sabe-se que o organismo, em situações de dificuldade respiratória, automaticamente procura uma posição corporal mais confortável, produzindo ações musculares e esqueléticas que modificam toda a postura corporal e induzem a vícios posturais e distúrbios do equilíbrio do corpo ${ }^{10}$.

Portanto a respiração oral trata-se de uma síndrome que apresenta como características o cansaço freqüente, a sonolência diurna, adinamia, falta de apetite, enurese noturna e até déficit de aprendizagem; além das alterações musculoesqueléticas e craniodentais. Assim, uma perturbação no sistema estomatognático determina uma resposta no corpo como um todo, sendo que o inverso também pode ocorrer ${ }^{19}$. Logo, a organização dos músculos em forma de cadeias obriga-nos a considerar a mecânica corporal de forma global e simultânea e justifica o comprometimento de toda a postura corporal quando existirem alterações craniofaciais ${ }^{20}$.

As cadeias musculares representam circuitos com continuidade de direção e de plano, por meio dos quais propagamse as forças organizadoras do corpo ${ }^{21}$. As cadeias musculares orofaciais e corporais inter-relacionam-se, funcionalmente, mediante sinergia neuromuscular.

O padrão postural das crianças antes dos 10 anos de idade varia constantemente, pois estão testando novas maneiras de reagir à gravidade. Durante a adolescência, a postura muda devido a alterações hormonais do início da puberdade e ao desenvolvimento músculo-esquelético. Entretanto, após a adolescência, há uma estabilização do crescimento e os padrões posturais se definem ${ }^{22}$.

$\mathrm{O}$ desenvolvimento neuropsicomotor normal caracteriza-se pela aquisição gradual do controle de postura, com o surgimento das reações de retificação e de equilíbrio. O desenvolvimento destas reações, controladas pelo Sistema Nervoso Central, permite ao indivíduo manter a postura e o equilíbrio da cabeça, tronco e extremidades em circunstâncias normais. Assim, a adequação da postura corporal da criança leva à melhora anatomo-funcional. Esta adequação também interfere no modo e no ritmo respiratório, favorecendo a coordenação desta com as demais funções do sistema estomatognático (sucção, mastigação e deglutição) ${ }^{23}$.

A criança que respira cronicamente pela boca necessita adaptar a sua postura da cabeça, anteriorizando-a para que o ar chegue mais rapidamente aos pulmões. Esse mau posicionamento da cabeça em relação ao pescoço traz alterações para coluna no sentido de compensar o desvio postural. Desse modo, surge uma cadeia de compensações posturais adaptativas em todo o organismo, como ombros em protrusão, retificação cervical e hiperlordose lombar, hipercifose dorsal, abdome proeminente, anteversão da pelve, joelhos hiperextendidos e pés pronados ${ }^{5,6,20}$. As alterações posturais decorrentes da respiração oral são evidentese complexas, porém poucos estudos comparam estas com as alterações comumente observadas em escolares em geral. Logo, o objetivo desse estudo foi avaliar a postura corporal de crianças respiradoras predominantemente orais e comparar com os achados da literatura referentes à postura de escolares em geral.

\section{MATERIAIS E MÉTODOS}

O projeto está de acordo com a Resolução 196/96 do Ministério da Saúde e foi aprovado pelo Comitê de Ética em Pesquisa da UFSM sob número 9362/2007.

O presente estudo, classificado como exploratório, quantitativo e qualitativo, foi desenvolvido no Serviço de Atendimento Fonoaudiológico da Universidade Federal de Santa Maria (SAF/UFSM), no período de março a dezembro de 2007. Compreendeu 30 pacientes, de ambos os sexos (15 sexo feminino e 15 sexo masculino), com idades variando de 8 anos e 11 meses a 13 anos e 3 meses, encaminhados por médico otorrinolaringologista e que passaram por triagem fonoaudiológica, confirmando a síndrome da respiração oral.

Não foram incluídas na amostra desta pesquisa crianças com idade inferior a 8 anos, pelas alterações inerentes ao processo de crescimento, ou superior a 14 , devido a estabilização postural; os problemas neurológicos ou ortopédicos; a deficiência visual ou auditiva; as crianças em tratamento fisioterapêutico ou que não fossem respiradoras orais.

Foi realizada avaliação postural subjetiva, considerando o grau de simetria e posicionamento das estruturas corporais nas vistas ântero-posterior, póstero-anterior e lateral direita. As crianças estavam em trajes de banho e foram observadas 
quanto ao alinhamento da cabeça, ombros, cristas ilíacas, joelhos e pés (vista anterior); simetria dos ombros, escápulas, cristas ilíacas e linhas poplíteas (vista posterior); posição da cabeça, ombros, curvas da coluna, pelve e joelhos (na vista lateral).

A análise foi executada mediante distribuição de frequiência das alterações encontradas. Os achados obtidos na avaliação postural das crianças com respiração predominante oral (CRPO) foram comparados aos achados descritos na literatura com relação à postura corporal de escolares em geral.

As pesquisas relacionadas à postura corporal de escolares em geral foram consultadas em base de dados nacionais e internacionais como: MEDLINE (Medical Literature Analysis and Retrieval System on Line), LILACS (Literatura LatinoAmericana e do Caribe em Ciências da Saúde) e SCIELO (Scientific Eletronic Library Online). Uma pesquisa on-line também foi realizada em busca de artigos publicados em páginas disponíveis na internet. As estratégias de busca incluíram as palavras-chave: postura, escolares, crianças, posture e school-age children. Para fins de comparação, foram considerados os estudos com crianças na faixa etária mais próxima a das crianças respiradoras predominantemente orais avaliadas nesta pesquisa.

\section{RESULTADOS}

Os resultados da avaliação postural demonstraram que as CRPO apresentaram maior número de alterações posturais comparado às alterações descritas nos estudos com escolares em geral (máximo de 12 versus máximo de 8 , respectivamente). A freqüência destas alterações também se apresenta mais elevada nas CRPO em relação aos achados de dois dos três trabalhos estudados. Na análise postural de CRPO, as alterações posturais predominaram no quadrante superior do corpo, ou seja, cabeça, ombros, membros superiores e escápulas conforme mostram as Tabela 1,2 e 3.

TABELA 1 - Ocorrência de alterações posturais em respiradores predominantemente orais - Vista perfil

\begin{tabular}{lcc}
\hline Postura & Freqüência & Porcentagem \\
\hline Cabeça anteriorizada & 25 & $78,13 \%$ \\
Cabeça fletida & 11 & $34,38 \%$ \\
Ombros protrusos & 22 & $68,75 \%$ \\
Rotação interna MMSS & 21 & $65,63 \%$ \\
Tórax deprimido & 8 & $25,00 \%$ \\
Retificação dorsal & 4 & $12,50 \%$ \\
Hipercifose dorsal & 9 & $28,13 \%$ \\
Hiperlordose lombar & 14 & $43,75 \%$ \\
Anteversão pélvica & 14 & $43,75 \%$ \\
Protrusão abdominal & 12 & $37,50 \%$ \\
Hiperextensão de joelhos & 5 & $15,63 \%$ \\
Antepulsão & 2 & $6,25 \%$ \\
\hline
\end{tabular}

NOTA: número total de crianças $-n=30$
TABELA 2 - Ocorrência de alterações posturais em respiradores predominantemente orais - Vista ântero-posterior

\begin{tabular}{lcc}
\hline Postura & Frequiência & Porcentagem \\
\hline Cabeça inclinada & 20 & $62,50 \%$ \\
Cabeça rotada & 10 & $31,25 \%$ \\
Ombros assimétricos & 26 & $81,25 \%$ \\
Ombros elevados & 1 & $3,13 \%$ \\
Flexão de cotovelo e dedos & 15 & $46,88 \%$ \\
Flexão de dedos & 12 & $37,50 \%$ \\
Joelhos valgos & 5 & $15,63 \%$ \\
Pés pronados & 22 & $68,75 \%$ \\
\hline
\end{tabular}

NOTA: número total de crianças $-n=30$

TABELA 3 - Ocorrência de alterações posturais em respiradores predominantemente orais -

Vista póstero-anterior

\begin{tabular}{lcc}
\hline \multicolumn{1}{c}{ Postura } & Freqüência & Porcentagem \\
\hline Escápulas abduzidas & 22 & $68,75 \%$ \\
Escápulas elevadas & 8 & $25,00 \%$ \\
Escoliose & 1 & $3,13 \%$ \\
Joelhos rotados internos & 5 & $15,63 \%$ \\
Joelhos rotados externos & 6 & $18,75 \%$ \\
\hline
\end{tabular}

NOTA: número total de crianças $-n=30$

De todos os artigos consultados na pesquisa em base de dados, especificamente, três foram considerados a fim de comparação nos resultados obtidos devido à equivalência dos objetivos propostos. Portanto, na TABELA 4 podem-se observar as compensações posturais presentes em escolares pesquisados por Neto ${ }^{24}$, Carenzi, Domenichelli, Zitti e Berbel ${ }^{25}$ e Penha, João, Casarotto, Amino e Penteado ${ }^{26}$.

\section{DISCUSSÃ $O$}

Estudos de Krakauer e Guilherme ${ }^{6}$ evidenciaram que as alterações posturais ocorrem igualmente entre crianças respiradoras nasais e orais até os 8 anos de idade; após esse período, o número de alterações é estatisticamente maior em crianças respiradoras orais, as quais mantêm um alinhamento corporal desorganizado. Essa desarmonia no eixo corporal se deve, principalmente, a influência da projeção da cabeça.

Analisando a TABELA 1 nota-se que a projeção anterior da cabeça foi a alteração mais freqüente no plano sagital $(78,13 \%)$, o que se justifica pela necessidade da criança adaptar a posição da cabeça para que o ar chegue mais rapidamente aos pulmões, diminuindo a resistência ao fluxo aéreo e o trabalho muscular. Tal achado condiz com a pesquisa de 
Débora Bonesso Andriollo Basso et al

TABELA 4- Ocorrência de alterações posturais mais freqüentes em escolares - Pesquisas

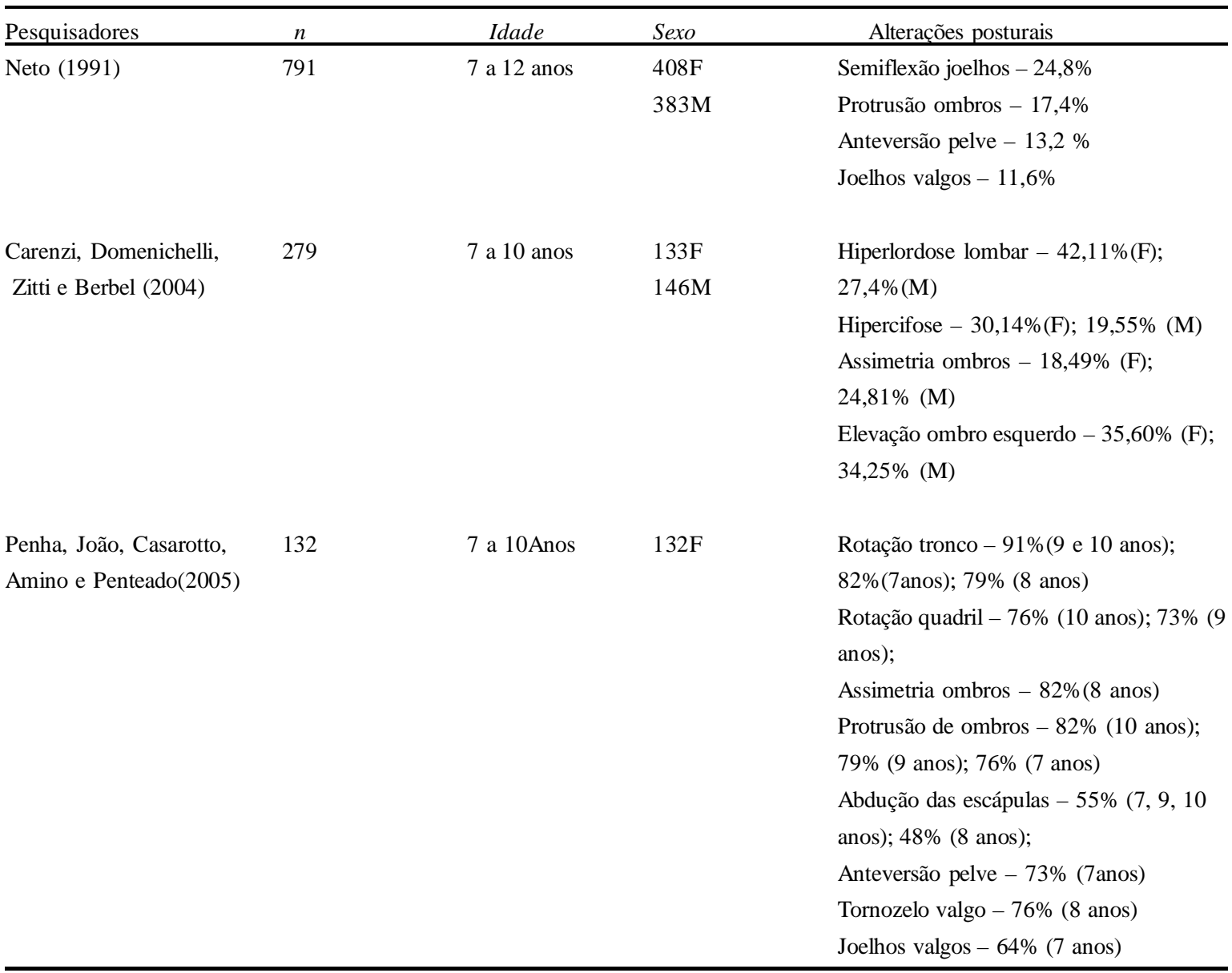

Siglas: $\mathrm{F}=$ feminino; $\mathrm{M}=$ masculino

Ribeiro-Corrêa, Marchiori e Silva ${ }^{20}$ que verificaram uma atividade eletromiográfica aumentada nos músculos trapézio superior e esternocleidomastoídeo de respiradores orais quando comparados a nasais, devido, provavelmente, à tensão necessária para a manutenção da postura anteriorizada da cabeça nesses indivíduos.

Lima, Baraúna, Sologurem, Canto e Gastaldi ${ }^{29}$ acrescentam que a projeção anterior da cabeça nos respiradores orais determina uma tensão aumentada nos músculos supra e infra- hióideos que são abaixadores e retrusores da mandíbula, provocando tensão no orbicular da boca na sua ação de selamento labial. Isto explica seu posicionamento entreaberto, com lábio superior retraído e inferior evertido.

As alterações na funcionalidade do sistema estomatognático provocam desequilíbrios que se manifestam à distância, no organismo como um todo. Segundo Krakauer e Guilherme ${ }^{6}$ a alteração na postura da cabeça, adaptando a angulação da laringe para facilitar a entrada do ar, muda a posição de repouso da mandíbula, os contatos oclusais, os planos ópticos e bipupilares. A essas mudanças seguirão movimentos adaptativos do corpo em busca de uma postura mais confortável e de equilíbrio.

A persistência da respiração oral determina um prejuízo na mecânica ventilatória, com desequilíbrio das forças musculares que podem produzir disfunções temporomandibulares, torácicas e, conseqüentemente, desvios em todos os eixos posturais $(27,28)$. Bricot ${ }^{19}$ também relata que o sistema estomatognático perturba o sistema tônico postural e este influencia o sistema estomatognático.

É importante a percepção de que a posição da cabeça e do pescoço em relação ao tronco tem efeito definido sobre o corpo. Para Barbiero, Vanderlei e Nascimento a respiração oral, em um primeiro momento, leva a uma extensão progressiva da cabeça, promovendo a retificação da coluna cervical. Posteriormente, por apresentarem alterações craniomandibulares e posturais, os respiradores orais tendem a impulsionar a mandíbula para adiante proporcionando um aumento da lordose cervical. Assim, quando a cabeça está projetada anteriormente a musculatura das escápulas e ombros também estará afetada, esses se enrolando sobre o peito e aquelas se elevando e abduzindo, visto que as cadeias musculares unem todas essas estruturas. A assimetria de ombros $(81,25 \%)$ foi a alteração postural mais freqüente, seguida da cabeça anteriorizada $(78,13 \%)$, da protrusão dos 
ombros e da abdução das escápulas e pés pronados (68,75\%), nos indivíduos pesquisados. Esses achados condizem com os estudos de Aragão ${ }^{5}$ que relata que quando a criança respira pela boca, ela flete o pescoço para frente, retificando o trajeto das vias respiratórias, as escápulas se elevam e o tórax fica deprimido. Também foi observado tórax deprimido nos indivíduos avaliados neste estudo, numa frequiência de $25 \%$.

Aragão ${ }^{5}$ acrescenta que essas alterações do tórax determinam uma respiração mais rápida e curta, com pequena ação do diafragma. O músculo reto abdominal está relaxado e a ingestão constante de ar leva a criança a ter o abdome protruso. Sabe-se que a musculatura abdominal é responsável pela estabilidade do esterno, costelas e coluna, contribuindo para respiração e para a fala. Nessa pesquisa $37,5 \%$ das crianças apresentavam protrusão abdominal.

Sá Filho apud Marins ${ }^{28}$ descreve as alterações posturais do respirador oral, semelhantes às encontradas nesta pesquisa, tais como: ombros protrusos, escápulas abduzidas, aumento das curvas fisiológicas da coluna, protrusão abdominal e pés pronados. Lima, Baraúna, Sologurem, Canto e Gastaldi ${ }^{29}$ encontraram em suas pesquisas com respiradores orais a projeção anterior da cabeça, retificação da coluna cervical, a retração do mento e um aumento da convexidade torácica. A hipercifose, no estudo em questão, esteve presente em $28,13 \%$ das crianças, enquanto a hiperlordose em $43,75 \%$. Os pés pronados tiveram uma freqüência de $68,75 \%$, o que caracteriza a hipotonia generalizada desses indivíduos. Porém, os joelhos valgos foram encontrados somente em 15,63\% das crianças estudadas, o que não confirma que esta alteração seja típica do respirador oral, conforme descreve Aragão ${ }^{5}$.

Corrêa e Bérzin ${ }^{30}$ avaliaram 19 crianças respiradores orais verificando anteriorização da cabeça e abdução das escápulas (68\%), rotação medial dos ombros (58\%), assimetria dos ombros (42\%) e inclinação lateral da cabeça (21\%); consoante com os resultados dessa pesquisa.

De acordo com Neto ${ }^{24}$, a postura da criança sofre grande transformação, dos 7 aos 12 anos de idade, na busca de equilíbrio compatível com as novas proporções do seu corpo. Contudo, aos poucos, se o desenvolvimento for normal, há uma reorganização natural do alinhamento postural.

Relacionando as alterações posturais encontradas nos respiradores orais avaliados com os estudos em escolares em geral deve-se considerar que o estudo de Penha, João, Casarotto, Amino e Penteado ${ }^{26}$ com escolares de 7 a 10 anos identificou a assimetria de ombros em $82 \%$ das crianças em geral. Carenzi, Domenichelli,

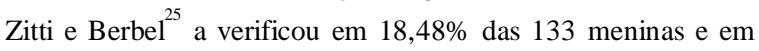
$24,81 \%$ dos 146 meninos avaliados em seu estudo. Neste estudo, esta assimetria foi observada em $81,25 \%$ dos respiradores orais. Logo, tendo por base essas pesquisas, supõe-se que tal assimetria não pode ser definida como característica do respirador oral.

Neto $^{24}$ avaliou a postura de 791 escolares, de ambos os sexos com idade entre 7 e 12 anos, encontrando a protrusão de ombros em 17,4\% das crianças. Penha, João, Casarotto, Amino e Penteado ${ }^{26}$ encontraram a protrusão de ombros como uma alteração postural freqüente ( $79 \%$ aos 9 anos e $82 \%$ aos 10 anos) entre as meninas, bem como a abdução das escápulas presente em $55 \%$ delas aos 7, 9 e 10 anos. No presente estudo observouse protrusão de ombros e abdução das escápulas em $68,75 \%$ dos respiradores orais, somados a essas alterações aparecem a inclinação da cabeça $(62,50 \%)$ e a sua anteriorização $(78,13 \%)$. Embora as alterações no posicionamento dos ombros e escápulas estejam presentes em ambos os grupos de crianças, a alteração na postura da cabeça não é mencionada nos estudos com escolares em geral e é freqüente nas CRPO avaliadas (anteriorizada em 78,13\% e inclinada em 62,50\%).

Nas avaliações em escolares, Neto ${ }^{24}$ encontrou $15,2 \%$ das crianças com anteversão de pelve, 11,6\% com joelhos valgos, $0,6 \%$ com padrão cifótico e 1,8\% com padrões lordóticos. Penha, João, Casarotto, Amino e Penteado ${ }^{26}$ verificou na avaliação postural de meninas de 7 a 10 anos a hiperlordose mais frequiente aos 8 e aos 10 anos (61\%), a hipercifose aos 9 e aos 10 anos (45\% e 42\%). Dos respiradores orais avaliados nesta pesquisa $43,74 \%$ apresentavam anteversão pélvica e hiperlordose lombar; $15,63 \%$ joelhos valgos e 28,13\% hipercifose. Com exceção da hipercifose, que é mais freqüente em meninas de acordo com Penha, João, Casarotto, Amino e Penteado ${ }^{26}$, os outros padrões posturais são mais acentuados nos respiradores orais.

Esses achados demonstram que embora ambos os grupos apresentem alterações posturais, as CRPO as tem numa freqüência mais elevada. Portanto, a alteração no padrão fisiológico da respiração acarreta uma série de conseqüências que vão além do sistema estomatognático do indivíduo. Catonni, Fernandes, DiFrancesco e Latorre ${ }^{10}$ refere que crianças respiradoras orais apresentam adaptações patológicas das características posturais e morfológicas do sistema estomatognático, sugerindo a importância do diagnóstico precoce como forma de evitar alterações orofaciais.

Cabe salientar que, nas avaliações posturais de escolares, o modo respiratório não é considerado e/ou avaliado. Portanto, os resultados dos estudos de avaliação postural de crianças escolares em geral podem abranger tanto respiradores nasais como orais ou mistos.

\section{CONCLUSÕES}

Conclui-se que o modo respiratório é fundamental no equilíbrio postural de crianças em idade escolar. $\mathrm{O}$ exame postural dos sujeitos desta pesquisa possibilitou demonstrar um padrão de alterações posturais mais freqüentes em respiradores orais, condizente com a literatura.

Observou-se que crianças respiradoras predominantemente orais apresentam alterações posturais especialmente no quadrante superior do corpo, tais como, anteriorização da cabeça, protrusão de ombros, abdução e 
elevação de escápulas. Entretanto, ficou evidente que algumas alterações são próprias do desenvolvimento postural normal, uma vez que apareceram em ambos os grupos. Entre essas, a assimetria e protrusão dos ombros, os joelhos valgos, a hiperlordose lombar, as quais tendem a ser corrigidas com o crescimento.

Sabe-se que a má postura no dia a dia, as mochilas pesadas e o sedentarismo podem contribuir para alterações na postura da criança no futuro $^{24-26}$. Porém, se somado a esses fatores, que são comuns à maioria das crianças, está o fato de respirarem predominantemente pela boca os padrões posturais anormais tendem a fixar-se. Logo, percebe-se que o modo respiratório é um fator que deveria ser incluído na avaliação de escolares, considerando a grande incidência da respiração oral e a sua repercussão sobre a postura corporal.

\section{REFERÊNCIAS BIBLIOGRÁFICAS}

1. West JB. Fisiologia respiratória. 6 ed. São Paulo: Manole, 2002. 2. Ferreira LP, Befi-Lopes DM, Limongi SCOL. (Org.) Tratado de Fonoaudiologia. São Paulo: Roca, 2004.

3. Lusvarghi L. Identificando o respirador bucal. Rev da APCD. 1999 jul-ago; 53(4):265-74.

4. Lampasso JD, Lampasso JG. Allegy, nasal obstruction and occlusion. Sem in Orthod. 2004 mar; 10(1):39-44.

5. Aragão W. Respirador bucal. Jornal de Pediatria. 1988; 64(8): 349-352.

6. Krakauer LH, Guilherme A. Relação entre respiração bucal e alterações posturais em crianças: uma análise descritiva. Rev da Sociedade Brasileira de Fonoaudiologia. Ano 2, suplemento 1, Novembro, 1998.

7. Fayyat, E. A influência de hábitos orais e respiração bucal no aparecimento de mordida aberta anterior em crianças com dentição decídua. Belo Horizonte, 1999. Especialização [Fonoaudiologia] Centro de Especialização em Fonoaudiologia Clínica - CEFAC.

8. Lemos CM. de.; Junqueira PA de S, Gomez MVSG, Faria MEJ de, Basso S de C. Estudo da relação entre oclusão dentária e a deglutição no respirador bucal. Arq Int Otorrinolaringol. 2006;10(2):114-118. 9. Barbiero EF, Vanderlei LCM, Nascimento PC. A síndrome da respiração bucal: uma revisão para a fisioterapia Rev Iniciação Científica Cesumar. 2002 ago-dez; 4(2):125-130.

10. Catonni DM, Fernandes FDM, DiFrancesco RC, Latorre, M do RD de O. Características do sistema estomatognático de crianças respiradoras orais: estudo antroposcópico. Pró-fono. 2007 outdez;19(4):347-51.

11. Frasson JMD, Magnani MBB de A, Nover DF, Siqueira VCV de, Lunardi, N. Comparative cephalometric study between nasal and predominantly mouth breathers. Rev Bras Otorrinolaringol. 2006;72(1):72-81

12. Menezes VA de, Leal RB, Pessoa RS, Pontes RMES. Prevalência de fatores associados a respiração oral em escolares participantes do projeto Santo Amaro-Recife, 2005. Rev Bras Otorrinolaringol.
2006;72(3):394-9

13. Overland B, Akre H, Skatvedt O. Oral breathing in pacients with sleep-related breathing disorders. Acta Otorrinolaringol. 2004; 112(112):651-55.

14. Lessa FCR, Enoki C, Feres MFN, Valera FCP, Lima WTA et al. Influência do padrão respiratório na morfologia craniofacial. Rev Bras Otorrinolaringol. 2005 mar-abr; 7(2):156-60.

15. Shanker S, Fields H, Beck FM, Wig PS, Vig KW. A longitudinal assessment of upper respiratory function and dentofacial morphology in 8 to 12 year-old children. Sem in Orthod. 2004 mar; 10(1):45-53.

16. Huggare JAV, Laine-Alava MT. Nasorespiratory function and head posture. Am J Orthod Dent Orthop. 1997 nov; 112(5):507-11.

17. Bianconi CC, Ribeiro F, Mesquita MCM, et alli. Respiração oral: alterações oclusais e hábitos orais. Rev CEFAC. 2002; 4:187190 .

18. Shitaka N, Ueda HM, Kato M, Tabe H, Nagaoka K et al. Association between nasal respiratory obstruction and vertical mandibular position. J Rehab. 2004; 31:957-962.

19. Bricot B. Posturologia. 2 ed. São Paulo: Ícone, 2001.

20. Ribeiro-Corrêa, E; Marchiori, S.C.; Silva, A.M. Eletromyographic muscle activity in mouth and nasal breathing children. J Craniomand Pract. 2004; 22: 45-50.

21. Tessitore A, Manicardi NA. Motricidade oral e voz. In: Tópicos em Fonoaudiologia. São Paulo: Lovise, 1996. cap. 41, p.621 - 627 .

22. Mongeo MT. Postura corporal X distúrbio miofuncional: relações e implicações no prognóstico terapêutico e fonoaudiológico. Porto Alegre, 1999. Especialização[Fonoaudiologia] - Centro de Especialização em Fonoaudiologia Clinica - CEFAC.

23. Val DC do, Limongi SCO, Flabiano FC, Silva KCL da. Sistema estomatognático e postura corporal na criança com alterações sensório-motoras. Pró-Fono-Revista de Atualização Científica, Barueri (SP), 2005 set.-dez; 17(3): 345-354.

24. Neto FR. Avaliação postural de escolares de $1^{\text {a }}$ a $4^{\text {a }}$ série do $1^{\circ}$ grau. Revista Brasileira de Ciência e Movimento.1991; 5(2). 25. Carenzi T, Domenichelli C, Zitti AC, Berbel AM. Avaliação postural em crianças em idade escolar de uma escola da cidade de Guarulhos - SP. Rev Fisioterapia-UNICID. 2004 jan-jun; 3(1):3948.

26. Penha PJ, João SMA, Casarotto RA, Amino CJ, Penteado DCP. Postural assessment of girls between 7 and 10 years of age. Clinics. 2005; 60(1):9-16.

27. Corrêa ECR, Bérzin F. Temporomandibular disorder and dysfunctional breathing. Braz J Oral Sci. 2004; 3:498-502.

28. Marins RS. Síndrome do respirador bucal e modificações posturais em crianças e adolescentes: importância da fisioterapia na equipe interdisciplinar. Rev. Fisioterapia em Movimento. 2001 abril-set; 15(1):45-52.

29. Lima LC de O, Baraúna MA, Sologurem MJJ, Canto, RS de 
Débora Bonesso Andriollo Basso et al

T, Gastaldi AC. Alterações posturais em crianças portadoras da Síndrome da Respiração Bucal avaliadas através do método da biofotogrametria computadorizada. J Appl Oral Sci. 2004;12(13):232-7.

Endereço para correspondência:

Juliana Alves Souza. Rua João Goulart, 540, apto 301,

Bairro Camobi, CEP: 97105220

Santa Maria, RS

Telefone: (55) 99740619; (55)2267213; (55) 30273700; (55) 30273700.

Email: fisioju@yahoo.com.br
30. Corrêa ECR, Bérzin F. Efficacy of physical therapy on cervical muscle activity and on body posture in school-age mouth breathing children. In J Pediatr Otorhinolaryngol. 2007;71:152735. 


\title{
INFLUENCIA DO CONCEITO NEUROEVOLUTIVO BOBATH NO TÔNUS E FORÇA MUSCULAR E ATIVIDADES FUNCIONAIS ESTÁTICAS E DINÂMICAS EM PACIENTES DIPARÉTICOS ESPÁSTICOS APÓS PARALISIA CEREBRAL
}

\author{
Influence of Bobath neuronal evolution concept in the muscle tonus and strength, static and \\ dynamics functional activities in diparetic spatic patients after cerebral palsy
}

Lívia Willemann Peres ${ }^{1}$, Aneline Maria Ruedell ${ }^{2}$ e Cristina Diamante ${ }^{3}$

\begin{abstract}
RESUMO
O objetivo desta pesquisa foi observar o tônus e a força muscular, juntamente com atividades funcionais estáticas e dinâmicas após tratamento por meio do Conceito Neuroevolutivo Bobath, em pacientes diparéticos espásticos devido a Paralisia Cerebral. Participaram do estudo quatro pacientes diparéticos espásticos com idade entre 6 a 8 anos, avaliados antes e após o tratamento. Avaliou-se o tônus muscular pela Escala de Ash Worth modificada e as atividades funcionais estáticas e dinâmicas e a força muscular. A pesquisa realizou-se na Clínica escola de Fisioterapia da Universidade do Oeste do Paraná, durante três meses. O tratamento constituiu-se de 25 sessões, duas vezes por semana com duração de 40 minutos. Houve uma diminuição do tônus e aumento da força muscular em grupos musculares específicos em todos os pacientes. Ainda verificou-se adequação em algumas atividades funcionais estáticas e dinâmicas. Conclui-se que o tratamento aplicado nestes pacientes proporcionou uma diminuição de tônus e aumento de força muscular, e conseqüente melhora nas atividades funcionais estáticas.

Palavras chave: Paralisia Cerebral, força muscular, tônus muscular, Conceito Bobath.

\section{SUMMARY}

The objective of this research was to observe the muscle tonus and strength together with the functional activities, after treatment by Bobath neuronal evolution concept, in diparetic spatic patients after cerebral palsy. Four diparetic spatic patients, aging from 6 to 8 years old, were evaluated before and after treatment. The muscle tonus, the static and dynamics functional activities and muscle strength were assessed by the modified Ashworth Scale. The research took place in the School Clinic of Physical Therapy of Universidade do Oeste do Paraná for three months. The treatment consisted of 25 sessions of 40 minutes, twice a week. There was a decrease in the tonus and an increase in muscle strength in specific muscle groups in all patients. Adequacy was also found in some static and dynamics functional activities. It can be concluded that the treatment in these patients provided a decrease in muscle tonus and an increase in muscle strength, and consequently an improvement in static functional activities.
\end{abstract}

Keywords: cerebral palsy, muscle strength, muscle tonus, Bobath concept.

${ }^{1}$ Pós graduada em fisioterapia clínica com ênfase em pediatria pela Universidade Estadual do Oeste do Paraná (UNIOESTE). ${ }^{2}$ Docente auxiliar de fisioterapia em pediatria; Universidade Estadual do Oeste do Paraná (UNIOESTE), Cascavel, PR; mestranda do programa de pós-graduação da Universidade Federal de Santa Maria (UFSM), Santa Maria, RS.

${ }^{3}$ Docente assistente de fisioterapia preventiva; Universidade Estadual do Oeste do Paraná (UNIOESTE), Cascavel, PR; mestre em engenharia de produção. 


\section{INTRODUÇ̃̃O}

A paralisia cerebral (PC) é definida como uma alteração da postura e do movimento, permanente, mas não imutável. Resulta de um distúrbio no cérebro não progressivo, devido a fatores hereditários, eventos ocorridos durante a gravidez, parto, período neonatal ou durante os primeiros dois anos de vida ${ }^{1}$.

A diparesia espástica é o principal tipo de paralisia cerebral em crianças recém-nascidas pré-termo. O exame clínico destas crianças revela fraqueza muscular, déficit de controle motor e espasticidade nos membros inferiores, com déficit nas habilidades motoras finas 2,3 .

Lesões hemorrágicas como a leucomálacia periventricular podem provocar o quadro clínico de diparesia espástica que afeta principalmente membros inferiores. Admite-se que um fator de grande importância patogênica seja a degeneração cística grave da substância branca. A gravidade do distúrbio motor parece manter relação com a extensão das anomalias reveladas pela tomografia computadorizada ${ }^{4}$.

A abordagem fisioterapêutica na PC teria a finalidade de preparar a criança para uma função, manter ou aprimorar as já existentes, atuando sempre de forma a adequar a espasticidade. Entretanto, o prognóstico da paralisia cerebral depende evidentemente do grau de dificuldade motora, da intensidade de retrações e deformidades esqueléticas e da disponibilidade e qualidade da reabilitação ${ }^{5}$.

Um dos métodos para tratamento de crianças com PC é o conceito Bobath que tem por objetivo incentivar e aumentar a habilidade da criança de mover-se funcionalmente da maneira mais coordenada possível. Os movimentos normais não podem ser obtidos se a criança permanecer em algumas posições e se mover de uma maneira limitada ou incoordenada, por inadequação do tônus postural anormal e incoordenação de postura e movimento presentes nestas crianças ${ }^{6}$.

O conceito Bobath parte do princípio de manuseios nos quais utilizamos padrões que irão influenciar o tônus muscular, pois, através dos pontos chaves de controle, estaremos produzindo mudanças no tônus muscular. Isto, conseqüentemente, irá influenciar o controle postural e o desempenho das atividades funcionais. A mudança de tônus, por sua vez, influenciará as características neurais e não neurais ${ }^{6}$.

Em longo prazo, a capacidade da criança em usar as habilidades que estão sendo facilitadas, dependerá da condição do sistema nervoso central (SNC) em adaptar-se a essas mudanças, incluindo a capacidade perceptiva e cognitiva do paciente no uso destas habilidades em um contexto ${ }^{7}$.

Estes fatores justificam a execução desta pesquisa, que apresenta como objetivo observar o tônus, força muscular e atividades funcionais estáticas e dinâmicas antes e após o tratamento fisioterapêutico com o Conceito Neuroevolutivo Bobath.

\section{MATERIAIS E MÉTODOS}

Este trabalho é derivado de um projeto de pesquisa aprovado pelo comitê de ética da Universidade Estadual do Oeste do Paraná - UNIOESTE (parecer 284/2007), desenvolvidos no ano de 2007, como pré-requisito para obtenção do título de pós-graduação.

A pesquisa realizada é do tipo quanti-qualitativo com corte longitudinal, de caráter explicativo segundo os objetivos da pesquisa. $\mathrm{O}$ universo estudado foi de pacientes diparéticos após paralisia cerebral, as quais foram avaliados antes e após o tratamento por meio do conceito neuroevolutivo Bobath. Os itens avaliados foram: tônus muscular conforme Ash Worth ${ }^{8}$, avaliação da força ${ }^{9}$, atividades funcionais de acordo com Durigon \& Sá ${ }^{10}$. O presente estudo realizou-se na Clínica de Fisioterapia da Universidade Estadual do Oeste do Paraná (UNIOESTE), no setor de pediatria.

Foram selecionados quatro voluntários, sendo três do gênero masculino e um do gênero feminino com idade de 06 a 08 anos, com diagnóstico de diparesia espástica moderada a leve, após Paralisia Cerebral. Para seleção da amostra os responsáveis pelos voluntários receberam um termo de consentimento livre esclarecido, para ser lido e assinado concordando em participar do estudo.

Os critérios de inclusão foram: pacientes diparéticos espásticos após Paralisia Cerebral; com idade entre 06 a 08 anos de idade; assinatura do termo de consentimento livre e esclarecido devidamente preenchido e assinado; marcha com ou sem apoio; ausência de cirurgias ortopédicas por um período de seis meses. Os critérios de exclusão foram: o direito do voluntário de abandonar a pesquisa a qualquer momento, sem a necessidade de justificar, a não entrega do termo de consentimento livre e esclarecido devidamente preenchido e assinado; a recusa em participar do projeto por livre e espontânea vontade; e mais de três faltas consecutivas ao tratamento.

Os Procedimentos para coleta de dados foram:

1. Tônus e força

As medidas de tônus foram realizadas através da Escala de Ash Worth modificada ${ }^{8}$ que leva em conta a reação ao alongamento muscular. Aavaliação foi realizada com o paciente deitado em um tablado em diferentes decúbitos, dependendo do grupo muscular a ser testado. O paciente deveria estar vestindo roupas adequadas, que não impedissem a realização do movimento. A temperatura do ambiente deveria estar agradável para o paciente, em torno dos $25^{\circ} \mathrm{C}$, para não interferir no tônus muscular. Durante a avaliação, o examinador utilizava mobilização passiva e sem comandos verbais. Logo após, o avaliador define o escore de 0 a 4 , de acordo com o resultado apresentado pela criança, conforme quadro I. 
Quadro I - Escala de Ashworth modificada para avaliação do grau de espasticidade.

Fonte: Quagliato, 1998.

\begin{tabular}{|l|l|}
\hline GRAUS & \\
\hline 0 & Sem aumento do tônus muscular \\
\hline 1 & $\begin{array}{l}\text { Leve aumento do tônus muscular manifestando-se como um resistir e ceder ou por mínima resistência na extensão } \\
\text { máxima do movimento passivo. }\end{array}$ \\
\hline $1+$ & $\begin{array}{l}\text { Leve aumento do tônus muscular manifestando-se como uma resistência que persiste de maneira discreta através da } \\
\text { extensão do movimento remanescente (menos da metade deste). }\end{array}$ \\
\hline 2 & $\begin{array}{l}\text { Aumento do tônus mais acentuado durante a maioria da extensão do movimento, mas com facilidade de se mover o } \\
\text { segmento acometido. }\end{array}$ \\
\hline 3 & Aumento considerável do tônus muscular, com dificuldade na movimentação passiva. \\
\hline 4 & O segmento acometido está rígido em flexão, extensão, abdução e adução (etc). \\
\hline
\end{tabular}

Em relação a avaliação da força muscular, esta foi testada através da capacidade muscular de desenvolver tensão contra uma leve resistência manual exercida pelo examinador ou pelo movimento realizado pela criança contra a ação da gravidade. Inicialmente, a criança foi posicionada em prono ou supino de acordo com o grupo muscular que foi avaliado. Em seguida, o segmento articular próximo ao grupo muscular a ser avaliado foi estabilizado. $\mathrm{O}$ examinador realizou um movimento passivo com o membro inferior da criança, no intuito de demonstrar para ela como esta deveria fazer o movimento ativamente. Logo após, a criança voltou à posição inicial e realizou o movimento demonstrado anteriormente ${ }^{9}$.

Quadro I I - Teste de força muscular.

Fonte: Reese, 2000.

\begin{tabular}{|c|l|}
\hline Graus & \\
\hline 0 & nenhuma evidência de contração pela visão ou palpação; \\
\hline 1 & ligeira contração, nenhum movimento; \\
\hline 2 & Movimento através da amplitude completa na posição com gravidadeeliminada; \\
\hline 3 & Movimento através da amplitude completa contra a gravidade; \\
\hline 4 & Movimento através da amplitude completa contra a gravidade e capazde prosseguir contra uma resistência moderada; \\
\hline 5 & Movimento através da amplitude completa contra a gravidade e capazde prosseguir contra uma resistência máxima. \\
\hline
\end{tabular}

Os grupos musculares a serem testados foram: extensores, adutores e abdutores de quadris (na posição prono), flexores de quadril, plantiflexores, dorsiflexores, inversores e eversores de tornozelo (na posição supina).

1. Atividades Funcionais

As atividades funcionais foram avaliadas, através da escala de atividades funcionais estáticas e dinâmicas ${ }^{10}$. Na avaliação de atividades funcionais dinâmicas (engatinhar e marcha), foram considerados os parâmetros quantitativos e qualitativos. Para o parâmetro quantitativo foi observada a capacidade de realização da atividade e, como parâmetro qualitativo, a presença ou ausência de normalidade no padrão de realização.

Quadro III - Escala de Avaliação das Atividades Funcionais Dinâmicas (engatinhar e marcha) desenvolvida para a amostra de crianças com Paralisia Cerebral.

Fonte: Durigon e Sá (2004)

\begin{tabular}{|c|l|}
\hline GRAU & Realização da atividade funcional \\
\hline 0 & Não realiza a atividade funcional \\
\hline 1 & Realiza a atividade em padrão anormal \\
\hline 2 & Realiza a atividade em padrão normal e coordenado, porém com alterações qualitativas. \\
\hline
\end{tabular}


Para a avaliação das atividades funcionais estáticas, as crianças foram orientadas a adotarem as seguintes posturas: sedestação, quadrupedia, ajoelhado, semiajoelhado e bipedestação, na seqüência do desenvolvimento motor. Para isto, foram utilizadas ordens claras e brinquedos como incentivo. Nesta avaliação foram observados parâmetros quantitativos como a capacidade de adotar e manter a postura e, como parâmetro qualitativo, a independência e alinhamento postural.

Quadro IV - Escala de Avaliação das Atividades Funcionais Estáticas (sedestação, quadrupedia, ajoelhado, semi-ajoelhado e bipedestação). Fonte: Durigon e Sá (2004).

\begin{tabular}{|c|l|}
\hline GRAU & Adoção e manutenção da postura \\
\hline 0 & não realiza a atividade funcional \\
\hline 1 & adota a postura com auxílio, mantém com apoio e sem alinhamento \\
\hline 2 & adota a postura com auxílio, mantém com apoio e com alinhamento \\
\hline 3 & adota a postura com auxílio, mantém sem apoio e sem alinhamento \\
\hline 4 & adota a postura com auxílio, mantém sem apoio e com alinhamento \\
\hline 5 & adota a postura sem auxílio, mantém com apoio e sem alinhamento \\
\hline 6 & adota a postura sem auxílio, mantém com apoio e com alinhamento \\
\hline 7 & adota a postura sem auxílio, mantém sem apoio e sem alinhamento \\
\hline 8 & adota a postura sem auxílio, mantém sem apoio e com alinhamento \\
\hline 9 & adota a postura sem auxílio, mantém sem apoio e realiza atividades na postura mantendo o alinhamento \\
\hline
\end{tabular}

A avaliação de tônus, força muscular e atividades funcionais foi aplicada em dois momentos, antes e após três meses de intervenção fisioterapêutica.

3. Protocolo de tratamento

O protocolo de tratamento foi através do Conceito Neuroevolutivo Bobath, cujo alvo principal é auxiliar a criança a mudar suas posturas e movimentos anormais de modo que possam se adaptar confortavelmente ao ambiente e desenvolver uma melhor qualidade nas habilidades funcionais. Foram realizados 3 meses de atendimentos, no período de setembro a novembro de 2007 , duas vezes por semana, com duração de 40 minutos cada terapia, totalizando 25 atendimentos.

A PC apresenta uma desordem de movimento e postura. Assim, no conceito Bobath é utilizado o termo padrões de movimentos e postura. E o conceito se baseia em controlar, modificar os padrões de movimento e postura inadequados, levando a criança exercer o movimento mais próximo do normal possível. Isso pode ser feito a partir de uma postura adotada pela criança, por exemplo, a postura ajoelhada com a extensão de pelve, e esta pode ser modificada para a postura de semi-ajoelhada com alinhamento corporal. São movimentos ativos e controlados pelo terapeuta com o objetivo de mobilizar ativamente articulações, controlar tônus e aumentar força muscular. Outra forma de atuação é promovendo o dinamismo dentro da mesma posição, ou seja, na postura ajoelhada com alinhamento podem ser trabalhadas rotações de tronco, auxiliando no controle postural e demonstrando para as crianças diferentes possibilidades funcionais, como o alcance, por exemplo. E assim, alongar e fortalecer cadeias musculares ${ }^{11}$.

O tratamento teve como objetivos a mobilização e controle de cintura pélvica, fortalecimento e controle de tronco, mobilização, alongamento e fortalecimento de grupos musculares dos quadris, joelhos e tornozelos. Como também o controle de posturas estáticas, melhoria de habilidades funcionais nestas posturas, além de mudanças de posturas.

\section{RESULTADOSE DISCUSSÃO}

Os resultados obtidos referentes ao tônus e força muscular e as atividades funcionais estáticas e dinâmicas, durante a avaliação e reavaliação seguem abaixo, na ordem dos pacientes A, B, C, D.

Os resultados do paciente $\mathrm{A}$ referentes ao tônus e à força da musculatura de membros inferiores (direito e esquerdo) mostraram diminuição do tônus muscular, após o tratamento, com escore de 2 para 1. Os grupos musculares foram: flexores de quadris, adutores de quadris, abdutores de quadris, rotadores mediais e flexores de joelho. Não houve mudança de tônus nos grupos musculares que já apresentavam o escore 1. A força muscular aumentou nos mesmos grupos musculares em que houve diminuição do tônus muscular, mas também nos rotadores laterais de quadris.

O paciente B apresentou diminuição do tônus muscular nos grupos de flexores de quadris, adutores de quadris, rotadores mediais de quadris e flexores de joelho e de tornozelo. Sendo que o escore destes músculos reduziu de 3 para 1, após o tratamento. Os músculos que não obtiveram mudança de tônus apresentavam escore 1 na avaliação inicial. A força muscular aumentou nos grupos de flexores de quadris, adutores de quadris e rotadores mediais de quadris, ou seja, nos mesmos grupos musculares que apresentaram diminuição de tônus muscular com o tratamento.

$\mathrm{O}$ paciente $\mathrm{C}$ teve diminuição do tônus muscular nos grupos de flexores de quadris, adutores de quadris, rotadores 
mediais de quadris e flexores de joelho, extensores de joelho e de tornozelo. $\mathrm{O}$ tônus muscular nestes grupos musculares reduziu de 2 para 1. Não houve alteração nos grupos musculares em que o escore foi de 1 na avaliação inicial. Dentre os músculos que tiveram diminuição do tônus, a força muscular somente não aumentou no grupo de extensores de tornozelo.

Sobre o paciente D, encontrou-se diminuição do tônus muscular nos grupos de flexores de quadris, adutores de quadris, rotadores mediais de quadris e flexores de joelho, extensores de joelho e flexores e extensores de tornozelo. O tônus muscular nestes grupos musculares reduziu de 2 para 1, após o tratamento. Não houve alteração nos grupos musculares em que o escore foi de 1 na avaliação inicial. A força muscular aumentou nos grupos de flexores de joelho extensores de tornozelo, músculos que também tiveram uma diminuição de tônus.

Ao descrever as atividades funcionais dinâmicas e estáticas dos pacientes A, B e C observou-se a melhora nas atividades estáticas de sedestação, quadrupedia e ajoelhado. O paciente D apresentou melhora somente em sedestação e quadrupedia, e este foi o paciente que apresentou aumento de força em um número menor de grupos musculares. Pela escala de atividades funcionais estáticas e dinâmicas, os valores mais expressivos nos pacientes A e C, que apresentaram nas posturas de quadrupedia e ajoelhado o aumento do escore de 1 para 7, após o tratamento. Porém, o paciente B que também teve uma relação entre diminuição de tônus muscular e força muscular, os escores aumentaram de 7 para 8 , na postura de quadrupedia e de 5 para 8 na posição ajoelhada. Cabe destacar que estas eram posturas em que o paciente já apresentava um maior controle. Nas atividades funcionais dinâmicas (engatinhar e marcha), os valores dos escores mantiveram-se os mesmos.

Um músculo com tônus aumentado apresenta encurtamento e consequentemente um número reduzido de sarcômeros, levando a uma diminuição da produção de força adequada para realizar um movimento eficiente. ${ }^{12}$

Estudos em portadores de Paralisia Cerebral demonstram a importância e a eficácia de fortalecimento muscular nesses pacientes, pois além de ganhar força muscular, ocorre uma melhora na função motora. Através de cargas repetitivas de exercícios, ocorrerá um crescimento do volume muscular, devido à hipertrofia das fibras musculares e aumento de unidades motoras dentro de cada sarcômero $^{2,13}$.

Na pesquisa de Liao H.F. et al (2007) ${ }^{14}$, crianças com diplegia espástica apresentaram ligeira melhora em suas habilidades motoras básicas e funcionais, da força muscular e do caminhar com mais eficiência, após a intervenção de um protocolo de fortalecimento muscular.

Em um estudo de Morton J.F., Brownlee M., McFadyen A.K. $(2005)^{15}$, oito crianças com PC foram submetidas a 18 atendimentos fisioterapêuticos. As crianças tiveram a força muscular aumentada em quadríceps e hamstrings. Estas alterações foram mantidas no follow-up. Houve uma diminuição do tônus muscular que continuou a diminuir no follow-up. Atividades como ficar em pé, andar, correr e saltar também tiveram evolução continuada.

Em todos os casos estudados, o padrão de aquisição motora não foi acompanhado de aumento do tono muscular, pelo contrário, houve diminuição deste, o que pode ser atribuído a capacidade de adaptação do fuso muscular a diferentes níveis de demanda através do processo de habituação, facilitada pelo atendimento fisioterapêutico ${ }^{12}$.

Os grupos musculares nos diparéticos espásticos, que apresentam espasticidade e contratura, tem sua principal ação no plano sagital, resultando em padrões e marchas características. Os músculos mais acometidos são: psoas, os "hamstrings", o reto femoral e gastrocnêmico ${ }^{3}$, o que justifica a escolha dos grupos musculares avaliados.

Quanto à avaliação das atividades funcionais estáticas, observamos neste estudo uma melhora descrita pela reavaliação nos quesitos sedestação, quadrupedia e ajoelhado. Vale ressaltar que o controle postural depende de um tônus postural adequado, e este é prejudicado em crianças com diparesia espástica devido a espasticidade encontrada. Porém com a facilitação motora, o tônus e o controle postural são modificados, tendo como conseqüência uma maior variedade de habilidades funcionais ${ }^{7}$.

Para Damiano, D.L. e Abel, M.F. (1998) ${ }^{16}$ a evolução em atividade funcionais, como a marcha, está diretamente relacionada com atividades que exijam força dos pacientes.

Considera-se uma alteração de tono mais significativa quando há uma menor capacidade de adaptação do fuso muscular ao movimento, manifestada pela presença de uma reação ao alongamento variável com a velocidade durante uma parte do arco de movimento ou em todo o arco de movimento, impossibilitando assim a manutenção ou mudanças de posturas $^{10}$. Como ocorreu uma adequada modulação do tônus muscular, melhorando a capacidade de adaptação do fuso muscular, houve condições adequadas para o fortalecimento muscular.

Ao considerar as capacidades motoras dessas crianças, as demandas da tarefa e as características do ambiente, observase que, muitas vezes, o padrão de locomoção apresentado por elas representa a melhor solução possível. Entretanto, algumas dessas soluções funcionais podem colocá-las em situação de risco para futuras alterações estruturais com aparecimento de encurtamentos, deformidades e prejuízo futuro na dinâmica da marcha ${ }^{12}$.

As características não neurais utilizam-se de alongamentos e contrações do músculo (plasticidade muscular), permitindo um melhor alinhamento biomecânico resultando em produção de força mais eficiente. Na questão da característica neural, os Padrões influenciando tônus (PIT's), alteram reflexos cutâneos e proprioceptivos, inicialmente recrutando o sistema de feedback e a longo prazo o sistema de 
feedforward. Os PIT's são aplicados para produzir modificações no corpo inteiro (uso de pontos chaves mais proximais), ou mobilizações específicas bem localizadas ${ }^{7}$.

Knox V. e Evans A.l. (2002) ${ }^{17}$ realizaram uma pesquisa que teve como objetivo de avaliar os efeitos funcionais do conceito Bobath. Quinze crianças com PC com idades com a média de idade de 7 anos e 4 meses foram submetidas ao tratamento baseado pelo conceito Bobath. Estas crianças tiveram importante evolução em relação a função motora.

\section{CONCLUSÃO}

Concluindo, é na limitação funcional, ou seja, durante o desempenho de atividades e tarefas da rotina diária que a incapacidade da criança émanifestada. Todas as argumentações feitas na teoria sobre a influência do tônus e da força muscular e sua correlação com as atividades funcionais, foram demonstradas neste estudo onde podem-se afirmar que houve uma diminuição do tônus e aumento da força muscular com uma conseqüente melhora das atividades funcionais estáticas nos pacientes com diparesia espástica após intervenção fisioterapêutica através do Conceito Neuroevolutivo Bobath.

\section{REFERÊNCIAS BIBLIOGRÁFICAS}

1. Leite JMRS, Prado GF. Paralisia cerebral aspectos fisioterapêuticos e clínicos. Rev. Neurociências 2004; 12: 42-45.

2. Bache CE, Selber P, Graham H K. The management of spastic diplegia. Currentorthopaedics 2003; 17: 88- 104.

3. Cargnin AM, Carla M. Proposta de tratamento fisioterapêutica para crianças portadoras de paralisia cerebral espástica, com ênfase nas alterações musculoesqueléticas. Rev Neurociências 2003; 11 : 34-39.

4. Bear MF, Connors BW, Paradiso M A. Neurociências, desvendando o sistema nervoso. São Paulo: 2 ed, artmed, 2002.

5. Peixoto ES, Mazzitelli C. Avaliação dos principais déficits e proposta de tratamento da aquisição motora rolar na paralisia cerebral

\section{$2004 ; 12$.}

6. Bobath B, Bobath K, Desenvolvimento Motor nos Diferentes Tipos de Paralisia Cerebral, 1 ed. São Paulo, Manole, 1989.

7. The Bobath Approach. London: The Bobath Centre for children with cerebral palsy. (citado em 01/12/2007). Disponível em: http://www.bobath.org.uk/.

8. Teive HAG, Zonta M, Kumagai Y. Tratamento da espasticidade: Uma atualização. Arq Neuropsiquiatr 1998; 56(4): 852-858.

9. Reese, N. B. Testes de função muscular e sensorial. Rio de Janeiro: Guanabara Koogan,

2000.

10. Durigon O F; Sá C.S.S; Sitta, L V. Validação de um protocolo de avaliação do tono muscular e atividades funcionais para crianças com paralisia cerebral. Rev.Neurociências 2004; 87 93.

11. The Bobath Centre. Notes to accompany the 8-week course in cerebral palsy. Londres, 1997.

12. Cury VCR, Mancini MC, Melo AP, Fonseca ST, Sampaio RF, Tirado MGA. Efeito do uso da órtese na mobilidade funcional de crianças com Paralisia Cerebral. Rev. Brás. Fisioter 2006;

13. Rosenbaum PL, Russel D J, Cadman, D. T.; Gowland C, Jarvis S, Hardy S. Measuring Change in Motor Function In Children with Cerebral Palsy: A Special Communication. Phys. Ther 1990; 70: 125-131.

14. Liao HF, Liu YC, Liu WY, Lin YT. Effectiveness of loaded sit-to-stand resistance exercise forchildren with mild spastic diplegia: a randomized clinical trial. Arch Phys Med Rehabil. 2007 88(1):25-31.

15. Morton, JF, Brownlee, M. McFadyen, AK. The effects of progressive resistance training for children with cerebral palsy. Clin. Rehabil. 19(3):283-289.

16. Damiano DL, Abel MF. Functional outcomes of strength training in spastic cerebral palsy. Arch Phys Med Rehabil. 1998, 79(2):119-125.

17. Knox, V, Evans, AL. Evaluation of the functional effects of a course of Bobath therapy in children with cerebral palsy: a preliminary study. Dev Med Child Neurol. 2002, 44(7):447460 .

Endereço para correspondência:

Aneline Maria Ruedell

Rua Pinheiro Machado, 2866/302

97050-600 Santa Maria RS - Brasil

Fone: 3026-8268. E-mail: aneruedell@yahoo.com.br 


\title{
POTENCIALANTIOXIDANTE IN VITRO, CONTEÚDO DE FENÓISE FLAVONÓIDESNOS RAMOS DE SCUTIA BUXIFOLIA REISSEK
}

\section{In vitro antioxidant potential, phenolic and flavonoids contents of Scutia buxifolia Reissek twigs}

\author{
Aline Augusti Boligon ${ }^{1}$, Bruna Ribeiro Magoga ${ }^{2}$, Andrieli Cassel Feltrin ${ }^{1}$, Vanessa Janovik ${ }^{3}$, Margareth Linde Athayde ${ }^{4}$
}

\begin{abstract}
RESUMO
O presente trabalho descreve a avaliação da atividade antioxidante pela metodologia do radical livre DPPH, o doseamento de polifenóis pelo método de Folin-Ciocalteau e teor de flavonóides no extrato bruto e nas frações dos ramos de $S c u t i a$ buxifolia (coronilha). O conteúdo de polifenóis e flavonóides variaram de 102,02 $\pm 0,71$ a 318,82 $\pm 1,62$ miligrama de ácido pirogálico por grama de planta seca e $83,47 \pm 0,93$ a 140,71 $\pm 2,14$ miligrama de rutina por grama de planta seca, respectivamente. $\mathrm{O} \mathrm{IC}_{50}$, concentração necessária para inibir a atividade do DPPH em $50 \%$ foi: extrato bruto $>\mathrm{CH}_{2} \mathrm{Cl}_{2}>$ AcOEt $>$ n-BuOH. No presente estudo foi possível estabelecer uma alta correlação positiva entre compostos fenólicos das frações e a atividade antioxidante destas $(0,99)$. Estes resultados indicam que $S$. buxifolia possui substâncias químicas capazes de capturarem radicais livres, compostos promissores na busca de fármacos antioxidantes contra doenças decorrentes do estresse oxidativo, sendo as frações n- $\mathrm{BuOH}$ e AcOEt as mais efetivas.
\end{abstract}

Palavras-chave: Scutia buxifolia, coronilha, DPPH, radicais livres.

\section{SUMMARY}

This work describes the antioxidant evaluation through the DPPH free radical methodology, the determination of polyphenol dosage by the method of Folin-Ciocalteau and the content of flavonoids in crude extract and fractions of the Scutia buxifolia twigs (coronilha). The content of flavonoids and polyphenols ranged from $102.02 \pm 0.71$ to $318.82 \pm$ 1.62 milligram of pirogallic acid per gram of dry plant and $83.47 \pm 0.93$ to $140.71 \pm 2.14$ milligram of rutin per gram of dry plant, respectively. The $\mathrm{IC}_{50}$ required concentration to inhibit the activity of DPPH at $50 \%$ was: crude extract > $\mathrm{CH}_{2} \mathrm{Cl}_{2}>\mathrm{AcOEt}>\mathrm{n}-\mathrm{BuOH}$. In this study it was established a high positive correlation between fractions of phenolic compounds and antioxidant activity of these (0.99). These results indicate that $S$. buxifolia has chemicals that are able to catch free radicals, promising compounds in the search for antioxidant drugs against diseases from oxidative stress, being the $\mathrm{n}-\mathrm{BuOH}$ and AcOEt fractions the most effective ones.

Key words: Scutia buxifolia, coronilha, DPPH, free radicals.

\section{INTRODUÇÃO}

A espécie Scutia Buxifolia pertence à família Rhamnaceae e é conhecida popularmente como coronilha. É nativa da América do Sul, ocorrendo principalmente no Rio Grande do sul, Argentina e Uruguai ${ }^{1,2}$, sendo usada popularmente como cardiotônica, hipotensora e diurética através da infusão em água da casca do caule ${ }^{1}$.

Os organismos vivos possuem sistemas antioxidantes endógenos para manter a formação de radicais livres em níveis toleráveis ${ }^{3}$. Estes sistemas não são $100 \%$ eficientes, pois quando os danos a biomoléculas são excessivos, eles podem levar alterações de funções e morte celular. Isso está relacionado com várias patologias, particularmente com as degenerativas associadas com a idade, como doenças cardiovasculares, neuropatias e câncer ${ }^{4}$. Por isso, o consumo de antioxidantes naturais, como os compostos fenólicos presentes na maioria das plantas, tem sido associado a uma menor incidência de

Trabalho realizado no Departamento de Farmácia Industrial da Universidade Federal de Santa Maria (UFSM) /RS

${ }^{1}$ Aluna do Curso de Pós - Graduação em Ciências Farmacêuticas da UFSM.

${ }^{2}$ Acadêmica formada no curso de Farmácia da UFSM.

${ }^{3}$ Aluna do curso de graduação de Farmácia da UFSM.

${ }^{4}$ Prof. Adjunta da UFSM 
doenças relacionadas ao estresse oxidativo ${ }^{5}$ O melhor método de prevenção é através de alimentação rica em antioxidantes como a vitamina $\mathrm{C}$ e a vitamina $\mathrm{E}$. A busca por substancias antioxidantes naturais vem aumentado nos últimos anos, motivo pelo qual, os centros de pesquisa e indústrias farmacêuticas têm investido cada vez mais neste tipo de pesquisa ${ }^{3}$.

As plantas, assim como os animais, têm em substâncias do metabolismo especial, como terpenos oxidados, taninos, fenóis, alcalóides, lignanas, cafeína e aminas, seus principais sistemas antioxidantes $^{6,7}$. Essas substâncias também contribuem com diversas funções ecológicas de extrema importância nas relações de competição nos ecossistemas terrestres, como polinização, alelopatia, defesa contra herbívoros e patógenos ${ }^{8,9}$.

Os vegetais são fontes de produtos naturais biologicamente ativos, muitos dos quais utilizados para síntese de inúmeros fármacos. Embora cerca de 100.000 compostos oriundos de plantas tenham sido identificados, as fontes de metabólitos secundários parecem ser inesgotáveis em relação às possibilidades de se encontrar novas e diferentes estruturas com atividades importantes à terapêutica e à agricultura ${ }^{10}$. O Brasil possui a maior diversidade genética vegetal do mundo, contando com mais de 55.000 espécies catalogadas de um total estimado entre 350.000 e 550.000 , devido a esta grande diversidade de espécies, aumentamse as chances de identificação de substâncias do metabolismo vegetal com atividades farmacológicas e descobrimento de novos alvos biológicos ${ }^{11}$.

Os radicais livres são moléculas muito reativas derivados de oxigênio e nitrogênio, formados fisiologicamente no corpo humano. Os antioxidantes podem ser definidos como substâncias capazes de retardas ou inibir a oxidação de substratos, podendo ser enzimáticos ou não enzimáticos, tais como á-tocoferol, â-caroteno, ácido ascórbico, compostos fenólicos e flavonóides ${ }^{12}$.

O objetivo deste estudo foi determinar a atividade antioxidante, o teor de compostos fenólicos e de flavonóides no extrato bruto e nas frações dos ramos de Scutia buxifolia.

\section{MATERIAL E MÉTODOS}

Coleta e extração do material vegetal:

Os ramos de Scutia buxifolia foram coletados em outubro de 2007, no município de Dom Pedrito, no estado do Rio Grande do Sul (coordenadas 30 $59^{\circ} 09^{\prime \prime}$ 'S e $54^{\circ} 27^{\prime} 44^{\prime \prime}$ W). O material testemunho (exsicata) está depositado no herbário do Departamento de Biologia da UFSM catalogado sob o número de registro SMBD 10919.

O material vegetal $(593,83 \mathrm{~g})$ foi seco ao ar livre e moído e triturado. $\mathrm{O}$ extrato foi obtido através da maceração hidroalcóolica (EtOH:H2O 7:3, v/v) do material que foi colocado em recipiente fechado e recoberto com o solvente, o macerado foi submetido a agitações manuais diárias, por um período de sete dias. Ao fim desse período o conteúdo foi filtrado em algodão, seguindo-se de concentração em evaporador rotatório, à temperatura inferior à $40^{\circ} \mathrm{C}$. Após a eliminação do etanol, o extrato bruto foi particionado através da extração seqüencial utilizando solventes de polaridade crescente: diclorometano $\left(\mathrm{CH} \mathrm{Cl}_{2}\right)$, acetato de etila (AcOEt) e n-butanol (n-BuOH)

Análise fitoquímica preliminar:

O screening fitoquímico dos ramos foi realizado como uma avaliação preliminar das classes de compostos presentes na planta. Esta análise fitoquímica seguiu a técnica descrita por Moreira (1979) ${ }^{13}$, abrangendo uma série de reações de caracterização (qualitativa) para extrato aquoso.

Avaliação da atividade antioxidante - DPPH:

Para a avaliação da atividade antioxidante foi utilizado o método fotocolorimétrico do DPPH (2,2-difenil,1picrihidrazila), segundo Choi et al. ${ }^{14}$. Foi utilizado o extrato bruto e as frações $\mathrm{CH} \mathrm{Cl}$, AcOEt e n-BuOH nas concentrações de: $250 ; 125 ; 62,5 ; 31,25 ; 15,62$ e 7,81 ìg/mL em etanol (2,5mL). A 2,5mL de cada amostra, foi adicionado $1 \mathrm{~mL}$ da solução de DPPH 0,3mM em etanol. Após 30 minutos, foram feitas as leituras, em espectrofotômetro (ShimadzuUV-1201) das absorbâncias a 518nm, onde o radical DPPH apresenta o máximo de absorção. Uma solução de DPPH ( $1 \mathrm{~mL}$; $0,3 \mathrm{nM})$ em etanol $(2,5 \mathrm{~mL})$ foi usada como controle negativo e uma preparação de ácido ascórbico como padrão (controle positivo), nas mesmas concentrações das amostras. O etanol foi usado para zerar o espectrofotômetro, tendo como brancos as soluções testes de cada amostra (sem adição do DPPH), visando minimizar a interferência de componentes das amostras na leitura. $\mathrm{O}$ ensaio foi realizado em triplicata e o cálculo da atividade antioxidante seguiu a equação:

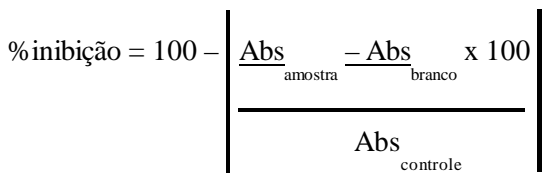

Onde: Abs é a absorbância da fração e do extrato bruto; Abs é a absorbância das frações e do extrato bruto sem adição do DPPH e Abs é a absorbância da solução de DPPH em etanol.

Foi calculada a percentagem de inibição do radical DPPH e construído um gráfico de porcentagem de inibição versus a concentração do extrato e das frações.

\section{Determinação de polifenóis:}

A determinação de conteúdos fenólicos totais foi realizada pelo método do Folin-Ciocalteau ${ }^{15}$ na concentração de 0,15 $\mathrm{mg} / \mathrm{mL}$ para as frações e o extrato bruto. As absorbâncias foram medidas em espectrofotômetro no comprimento de onda de $730 \mathrm{~nm}$, em triplicata. O conteúdo de polifenóis totais foi 
expresso em miligramas equivalentes de ácido pirogálico por grama de planta seca. A equação obtida para a curva padrão do ácido pirogálico foi $\mathrm{y}=34.443 \mathrm{x}-0.0942(\mathrm{r}=0.9994)$. As médias obtidas para cada fração foram comparadas entre si pelo teste de Tukey em 5\% de probabilidade de erro.

Doseamento de flavonóides:

A determinação do teor de flavonóides foi realizado segundo o método descrito por Woisky e Salatino ${ }^{16}$, a $1 \mathrm{~mL}$ de uma solução da amostra $(150 \mu \mathrm{g} / \mathrm{mL})$ das frações e extrato bruto de S. buxifolia, foram adicionados $0,5 \mathrm{~mL}$ de uma solução de $\mathrm{AlCl} 2 \%$. Após 15 minutos, as absorbâncias foram lidas em $420 \mathrm{~nm}$. Os testes foram realizados em triplicata e para o cálculo do doseamento de flavonóides utilizou-se a curva padrão de rutina ( $\mathrm{Y}=20,394 \mathrm{x}-$ 0,2033 ( $\mathrm{r}=0,9997)$. Os teores de flavonóides foram determinados em miligrama de rutina por grama de planta seca.

\section{RESULTADOS E DISCUSSÃO}

O rendimento das frações dos ramos de S. buxifolia está representado na Tabela 1, os maiores rendimentos foram obtidos para a fração n-BuOH, seguido da fração $\mathrm{AcOEt}$ e $\mathrm{CH}_{2} \mathrm{Cl}_{2}$.
Tabela 1 - Rendimento expresso em gramas e percentagem para as frações dos ramos de Scutia buxifolia Reissek.

\begin{tabular}{lc}
\hline Frações & Rendimento das frações (gramas e \%) \\
\hline $\mathrm{CH}_{2} \mathrm{Cl}_{2}$ & $1,0172 \mathrm{~g}(0,17 \%)$ \\
$\mathrm{AcOEt}$ & $1,6923 \mathrm{~g}(0,28 \%)$ \\
$\mathrm{n}-\mathrm{BuOH}$ & $4,2933 \mathrm{~g}(0,72 \%)$ \\
\hline
\end{tabular}

A capacidade de inibir a formação de radicais livres é medida pela descoloração da solução etanólica pelo DPPH segundo o método descrito por Choi et al. ${ }^{14}$. A solução de DPPH absorve na banda de $518 \mathrm{~nm}$ que mede a intensidade da coloração violeta. Na presença de boa atividade contra radicais livres ocorre descoloração ${ }^{17}$. A atividade medida pelo DPPH é usada muitas vezes como parâmetro para avaliar o poder antioxidante de extratos de plantas in vitro, que pode ser relacionada a compostos fenólicos e flavonóides presente ${ }^{18}$.

Em nosso estudo foi encontrado 96,35\% e 95,83\% de inibição do DPPH na concentração de 250 ìg/mL, para n$\mathrm{BuOH}$ e AcOEt, respectivamente. Essas frações apresentaram uma atividade rápida e forte, uma vez que, na menor concentração $(7,81 \mathrm{ìg} / \mathrm{mL})$ foi muito significativa essa atividade, representando 67,99\% de inibição para a fração n-BuOH e

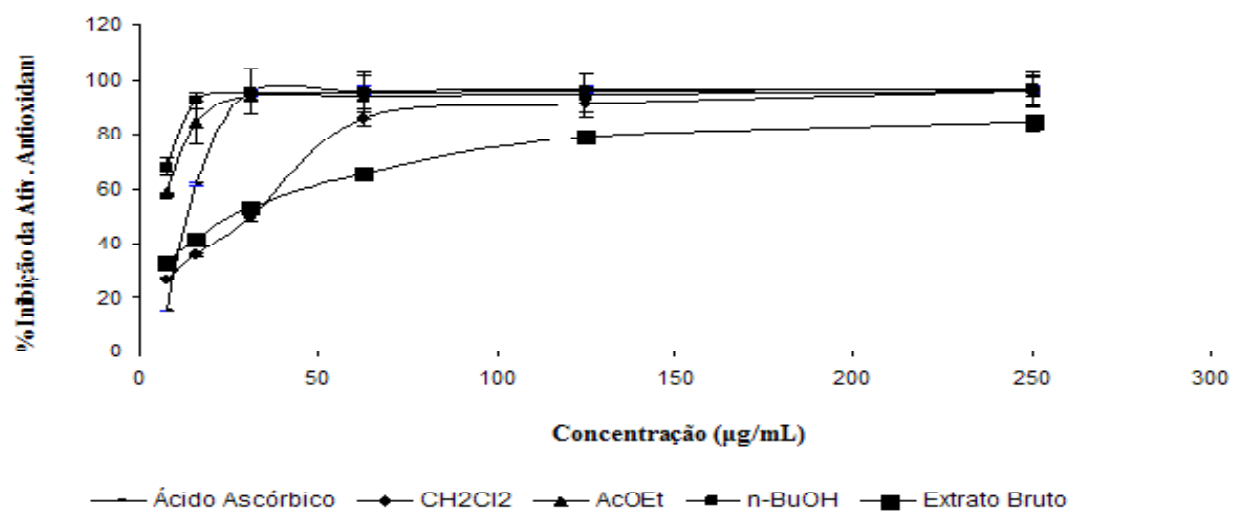

FIGURA 1-Percentual da atividade antioxidante do ácido ascórbico (padrão), do extrato bruto e das frações $\mathrm{CH}$ dos ramos de Scutia Buxifolia.

$58,31 \%$ para AcOEt, este comportamento não ocorreu com a fração $\mathrm{CH} \mathrm{Cl}$ que na menor concentração apresentou uma inibição de $26,49 \%$ (figura 1). Este comportamento pode ser entendido pela concentração dessas frações que apresentam compostos com propriedades polares, como é o caso de compostos fenólicos e flavonóides, os quais possuem comprovada atividade antioxidante. Vários trabalhos mostram a maior potência de extratos de fração n-BuOH e AcOEt em testes de atividade antioxidante. Tseng et al. ${ }^{19}$, fazendo uso do mesmo ensaio (DPPH) em extratos de folhas de Hibiscos sabdariffa, testaram extratos de várias polaridades e foi constatada que a fração AcOEt apresentava maior porcentagem no índice de inibição.
Tendo em vista a atividade antioxidante demonstrada nas frações, o IC (índice que descreve a concentração necessária para inibir a atividade do DPPH em 50\%) para o extrato bruto, as frações e para o ácido ascórbico foi calculado. $\mathrm{O} \mathrm{IC}$ da fração $\mathrm{CH} \mathrm{Cl}$ foi obtido através da equação da reta $\mathrm{y}=0,8559 \mathrm{x}+25,816 \stackrel{2}{2}(\mathrm{R}=0,9998)$, considerando os quatro primeiros pontos da curva, resultando no $\mathrm{IC}_{50}$ de $21,78 \pm$ $1,23 \mu \mathrm{g} / \mathrm{mL}$. Para o extrato bruto a equação obtida foi $\mathrm{y}=$ 0,6879x + 30,2109 $(\mathrm{R}=0,9982)$, com $\mathrm{IC}_{50}$ de 34,57 $\pm 0,98$.

Para o ácido ascórbico e as frações AcOEt e n-BuOH, o IC foi estimado matematicamente a partir da primeira concentração utilizada $(7,81 \mu \mathrm{g} / \mathrm{mL})$, que demonstrou atividade 
antioxidante próxima ou superior a $50 \%$, já que para essas frações e para o ácido ascórbico não foi possível demonstrar linearidade nas demais concentrações testadas. O IC estimado para a fração $\mathrm{n}$-BuOH e AcOEt foi de 5,74 $\pm 0,40 \mathrm{mg} / \mathrm{mL}$ e 6,69 $\pm 0,76$, respectivamente (Tabela 2 ). O ácido ascórbico, cuja atividade antioxidante é bastante documentada, apresentou um IC de 15,98 $\pm 0,12 \mathrm{mg} / \mathrm{mL}$

As frações n-BuOH e AcOEt apresentaram IC inferiores ao do ácido ascórbico, demonstrando uma excelente atividade antioxidante, superior àquela manifestada pelo ácido ascórbico. Esses baixos valores de $\mathrm{IC}_{50}$ evidenciados nas frações de $S$. buxifolia, sugerem a presença de compostos com forte atividade antioxidante, principalmente nas frações n-BuOH e AcOEt. Estes resultados são semelhantes aos reportados por Tung et al. ${ }^{20}$, analisando a capacidade antioxidante de frações obtidas das raízes de Acácia confusa pelo método do DPPH, onde os autores descrevem as melhores atividades antioxidantes e os menores valores de IC ${ }_{50}$ para as frações AcOEt e n-BuOH

A Tabela 2 apresenta os conteúdos de polifenóis e flavonóides do extrato bruto e das frações dos ramos de $S$. buxifolia. Os resultados indicam que a concentração destes compostos foi n-BuOH $>\mathrm{AcOEt}>\mathrm{CH}_{2} \mathrm{Cl}_{2}>$ Extrato bruto. É bem documentada a concentração superior de fenólicos nas frações n-BuOH e AcOEt quando os extratos são fracionados com solventes de polaridade crescente ${ }^{1,20,21,22}$.

Vários autores descrevem uma positiva correlação entre conteúdos fenólicos e atividade antioxidante usando DPPH e Folin-Ciocalteau para as análises ${ }^{1,20,23}$. No presente estudo foi possível estabelecer uma alta correlação positiva entre compostos fenólicos das frações com a atividade antioxidante destas $(0,99)$.

Tabela 2 - Doseamento de polifenóis (P), flavonóides (F) e IC ${ }_{50}$ do extrato bruto e das frações dos ramos de Scutia buxifolia Reissek.

\begin{tabular}{lllc}
\hline Frações/Extrato & $\mathbf{P}$ (mg AP/g PS) $\mathbf{D P P}$ & $\mathbf{F}$ (mg Rut/g PS) $\pm \mathbf{~ D P}$ & IC $_{50}$ \\
\hline Extrato bruto & $102,02 \pm 0,71 \mathrm{a}$ & $83,47 \pm 0,93 \mathrm{a}$ & $34,57 \pm 0,98$ \\
$\mathrm{CH} \mathrm{Cl}_{2}{ }_{2}$ & $121,59 \pm 0,66 \mathrm{~b}$ & $93,21 \pm 1,23 \mathrm{~b}$ & $21,78 \pm 1,23$ \\
$\mathrm{AcOEt}$ & $315,14 \pm 1,20 \mathrm{c}$ & $137,28 \pm 0,39 \mathrm{c}$ & $6,69 \pm 0,76$ \\
n-BuOH & $318,82 \pm 1,62 \mathrm{c}$ & $140,71 \pm 2,14 \mathrm{c}$ & $5,74 \pm 0,40$ \\
\hline
\end{tabular}

* Médias seguidas por letras diferentes diferem entre si pelo teste Tukey em 5\% de probabilidade de erro.

$\mathrm{AP}=$ Ácido pirogálico, Rut = rutina, $\mathrm{PS}=$ planta seca e DP = desvio padrão da média.

$\mathrm{IC}_{50}=$ concentração necessária para inibir $50 \%$ da atividade oxidante $(\mu \mathrm{g} / \mathrm{mL})$.

A Avaliação fitoquímica preliminar (screening) de S. buxifolia indicou a presença de cumarinas, ácidos orgânicos, heterosídeos flavônicos, heterosídeos cianogênicos, fenóis e alcalóides. A presença de flavonóides e heterosídeos cianogênicos encontrados no screening preliminar justificam a boa atividade antioxidante e elevados conteúdos fenólicos.

Os resultados encontrados em nosso estudo indicam que essa espécie possui substâncias químicas capazes de capturarem radicais livres, compostos promissores na busca de fármacos antioxidantes que previnem doenças decorrentes do estresse oxidativo. No entanto, o teste do DPPH não permite uma precisa definição dos efeitos antioxidantes por se tratar de uma metodologia in vitro ${ }^{24}$. Sabendo-se que a atividade de extratos de plantas não pode ser avaliada somente por um método ${ }^{14}$, torna-se necessário um estudo in vivo para determinar se esta planta medicinal poderá ser utilizada industrialmente.

\section{CONCLUSÃO}

Os baixos valores de IC encontrados para as frações n$\mathrm{BuOH}$ e AcOEt indicam uma forte atividade antioxidante, um alto conteúdo de polifenóis e de flavonóides nos ramos de Scutia buxifolia, estas frações serão priorizadas para ensaios biodirecionados visando o isolamento destes compostos.

\section{AGRADECIMENTOS}

À Bióloga mestre em Botânica Nelci Rolim Basto Zacchia, Departamento de Botânica da Universidade Federal de Santa Maria, por proporcionar a identificação de Scutia buxifolia.

\section{REFERÊNCIAS BIBLIOGRÁFICAS}

1. Wasicky R, Wasicky M, Joachimovits R. Erstuntersuchungen na Coronilha - Scutia buxifolia Reissek. Planta Medica 1964; 12: 13-25.

2. Menezes ACS, Mostardeiro M A, Zanatta N, Morel A. F. Scutianina-J, A New Cyclopeptidic Alkaloid Isolated From Scutia Buxifolia Reiss. Phytochemistry 1995; 28: 783-786.

3. Gordon MH. Dietary antioxidants in disease prevention. Natural Products Report 1996; 4: 265-272. 
em: <htt:/www.1,Anhembi.Br/halunos/farmácia/radical/index.htm>. Acesso em: mar. 2008.

5 . Droge W. Free radicals in the physiological control of cell function. Physiological Reviews 2002; 82: 47-95.

6. Larson RA. The antioxidants of higher plants. Phytochemistry 1988; 27(4): 969-978.

7. Cotelle AC. Antioxidant proprieties of hydroxy-flavones. Free Radical Biology and Medicine 1996; 21: 35-43.

8. Gottieb OR. The role of oxygen in phytochemical evolution towards diversity. Phytochemistry 1989; 28 (10): 2545-2558.

9. Langenhein JH. Higher plant terpenoides: a phytocentric overview of their ecological roles. Journal of Chemical Ecology 1994; 20(6): 1223-1280.

10. Yunes RA, Calixto JB. In: Plantas medicinais - sob a ótica da química medicinal moderna. Chapecó: Argos, 500pp, 2001.

11. Simões CMO, Schenkel EP, Gosmann G, Mello JCP, Mentz LA, Petrovick PR. Farmacognosia: da planta ao medicamento. 5 ed. Porto Alegre/Florianópolis: Editora da UFRGS / Editora UFSC, 2003.

12. Halliwell B. Free radicais and other reactive species in disease. In: Encyclopedia of Life Sciences. Nature Publishing Group 2001; 17.

13. Moreira EA. Contribuição para o estudo fitoquímico de Lobelia hassleri A. Zahlb e Lobelia stellfeldii R. Braga. Companulaceae. Tribuna Farmacêutica 1979; 47 (1): 13-39.

14. Choi CW, Kim SC, Hwang SS, Choi BK, Ahn HJ, Lee MY, Park SH, Kim SK. Antioxidant activity and free radical scavenging capacity between Korean medicinal plants and flavonoids by assay-guided comparison. Plant Sci 2002; 163: 1161-1168.

15. Chandra S, Meija EG. Polyphenolic Compounds, Antioxidant Capacity, and Quinone Reductase Activity of an Aqueous Extract of Ardisia compressa in comparison to Mate (Ilex paraguariensis) and Green (Camellia sinensis) Teas. J. Agric Food Chemistry 2004; 52: 3583-3589.
16. Woisky RG, Salatino A. Analysis of própolis: some parameters and procedures for chemical quality control. Journal Apicultural Research 1998; 37 (2): 99-105.

17. Kulisic T, Radonic A, Katanilic V, Milos M. Use of different methods for testing antioxidative activity of oregano essential oil. Food Chem 2004; 85: 633-640.

18. Rice-Evans CA, Miller NJ, Paganga G. Structure - antioxidant activity relationships of flavonoids and phenolic acids. Free Rad Biol Med 1996; 20(7): 933-956.

19. Tseng TH, Kao ES, Chu CY, Chou FP, Lin HW, Wang CJ. Protective effects of dried flower extracts of Hibiscus sabdariffa L. Against oxidative stress in rat primary hepatocytes. Food and Chemical Toxicology 1997; 35(2): 1159-1164.

20. Tung, YT, Wu JH, Kuo YH, Chang ST. Antioxidant activities of natural phenolic compounds from Acacia confusa bark. Bioresource Technology 2007; 98(5): 1120-1123.

21. Schubert A, Pereira DF, Zanin FF, Alves SH, Beck RCR, Athayde ML. Comparison of antioxidant activities and total phenolic and methylxanthine contents between the unripe fruit and leaves of Ilex paraguariensis A. St. Hil. Die Pharmazie 2007 , in press.

22. Turkmen N, Sari F, Velioglu YS. Effects of extraction solvents on concentration and antioxidant activity of black and black mate tea polyphenols determined by ferrous tartrate and FolinCiocalteu methods. Food Chem. 2006; 99: 835-841.

23. Shyamala BN, Gupta S, Lakshmi A, Prakash J. Leafy vegetable extracts - antioxidant activity and effect on storage stability of heated Oils. Innovative Food Science \& Emerging Technologie 2005; 6: 239-245.

24. Ursini F, Maiorino M, Marazzoni P, Roveri A, Pifferi G. A novel antioxidant flavonoid (idb 1031) affecting molecular mechanisms of cellular activation. Free Radical Biology \& Medicine 1994; 16(5): 547-553.

Endereço para correspondência:

Aline Augusti Boligon

Rua Coronel Niederauer, 1565, apto 209.

CEP: 97114-122, Santa Maria - RS - Brasil.

Fone: (55) 3011-7356/ 9952-2577.

E-mail: alineboligon@ hotmail.com 


\title{
DANÇATERAPIA EM PACIENTE DIPARÉTICO ESPÁSTICO
}

\author{
Dance therapy in diparetic spastic patient
}

Silvia Maria Tessaro ${ }^{1}$, Aneline Maria Ruedell ${ }^{2}$, Carlos Eduardo Albuquerque ${ }^{3}$, Cristina Diamante ${ }^{4}$

\begin{abstract}
|RESUMO
O objetivo foi de verificar a influência de um protocolo de dança no controle postural através da análise do centro de pressão da base de sustentação e marcha de paciente com seqüela de paralisia cerebral. A metodologia foi selecionar uma paciente do sexo feminino, 12 anos, com paralisia cerebral e seqüela de diparesia espástica. A paciente foi avaliada através da escala Gross Motor Function Measure e do protocolo software de análise postural, antes e após tratamento com dança. A partir da soma dos itens do Gross Motor Function Measure obteve-se um aumento do escore, o relatório gerado pelo software de análise postural ofereceu resultados sobre centro de gravidade da paciente obtendo diminuição da assimetria no plano frontal e no plano sagital. Concluiu-se que controle postural e marcha da paciente com paralisia cerebral foram influenciados positivamente pela dançaterapia.

Palavras Chave: Paralisia Cerebral, Postura, Dançaterapia.

\section{SUMMARY}

The objective was to study the influence of a dance protocol in postural control by analyzing the base pressure center of support and gait of a patient with sequelae of cerebral palsy. The methodology consisted of a selection of a 12-year-old female patient with cerebral palsy and diparetic spatic neurological sequelae. The patient was evaluated through the Gross Motor Function Measure Scale and through the software protocol for posture evaluation, before and after the dance treatment. An increase of the score was obtained by the sum of the Gross Motor Function Measure; the report generated by the software program, for posture evaluation, showed results concerning the gravity center of the patient resulting in decrease in asymmetry for the frontal and sagittal plans. It was concluded that the postural control and gait of the patient, with cerebral palsy, were influenced positively by dance therapy.

Keywords: cerebral palsy, posture, dance therapy.
\end{abstract}

\section{INTRODUÇ̃̃O}

Paralisia Cerebral (PC) ou encefalopatia crônica não progressiva da infância é uma lesão cerebral estática ocorrida no período pré, peri ou pós-natal que causa anormalidades no desenvolvimento por alteração durante a maturação do sistema nervoso central. ${ }^{1} \quad$ A alteração da postura e movimento será permanente, mas não imutável ${ }^{2}$.

$\mathrm{O}$ acometimento motor acarreta em dificuldade de controle sobre os movimentos além de alterações da dimensão muscular e em casos mais extremos em deformidades ósseas. Esta dificuldade no controle do movimento pode interferir na função dificultando a qualidade das atividades ${ }^{3}$.
Dependendo do comprometimento podem-se diferenciar os pacientes em diparéticos, hemiparéticos, quadriparéticos. As crianças diparéticas, por exemplo, apresentam o corpo todo afetado, mas as pernas são mais afetadas que os braços e tronco, com distribuição geralmente simétrica da espasticidade. E estas apresentam dificuldades no controle postural e em realizar atividades com seus membros inferiores. Para sustentar a mobilidade, a criança diparética adapta suas funções com inúmeras alterações posturais que prejudicam suas atividades diárias .

A musculatura destas crianças deverá apresentar um

${ }^{1}$ Fisioterapeuta, especialista pela Universidade Estadual do Oeste do Paraná (UNIOESTE), Cascavel, PR.

${ }^{2}$ Docente de fisioterapia em pediatria; Universidade Estadual do Oeste do Paraná (UNIOESTE), Cascavel, PR e mestranda do programa de pós-graduação da universidade Federal de Santa Maria (UFSM), Santa Maria, RS.

${ }^{3}$ Docente de fisioterapia em neurologia; Universidade Estadual do Oeste do Paraná (UNIOESTE), Cascavel, PR.

${ }^{4}$ Docente de fisioterapia preventiva; Universidade Estadual do Oeste do Paraná (UNIOESTE), Cascavel, PR. 
tônus suficiente para manter a postura ou o movimento contra a gravidade e força muscular adequada para que seu déficit não prejudique os movimentos funcionais. Os distúrbios motores e posturais afetam principalmente quando a criança tenta realizar o movimento voluntário e complexo coordenado, sem obtenção de êxito, pois acaba por provocar movimento descoordenado, esteriotipado e limitado ${ }^{5}$.

O controle postural consiste em um processo sofisticado que necessita da manutenção das articulações, grupos musculares, informações visuais, vestibulares e proprioceptivas para percepção e detecção de variações de movimento. A avaliação postural é um procedimento fundamental no diagnóstico do alinhamento dos segmentos corporais de um indivíduo, constituindo um processo contínuo de coleta de informações que ajudam no planejamento de tratamento clínico ${ }^{6}$.

Na Paralisia Cerebral a lesão no encéfalo imaturo produz sintomas que contribuem para a disfunção do sistema de controle postural de forma variável conforme origem e consequiência. O controle postural pode ser citado como o principal distúrbio encontrado na $\mathrm{PC}^{7}$

Para avaliar a motricidade de maneira quantitativa tem-se a Medição da Função Motora Grossa (GMFM), uma escala desenvolvida por Russel et al em 1989, na Universidade McMaster, no Canadá ${ }^{8}$ É um instrumento avaliativo utilizado em muitos estudos com crianças com $\mathrm{PC}^{9}$. Entre os estudos, pode ser citada a pesquisa realizada por Chagas et al (2008) ${ }^{10}$ que teve o objetivo de comparar as habilidades motoras de grupos de crianças com PC utilizando a escala GMFM. O trabalho realizado por Casady e Nichols-Larsen (2004) ${ }^{11}$, utilizou a GMFM para mensurar os efeitos da equoterapia em crianças com PC.

$\mathrm{Na}$ avaliação da postura temos o Software para Avaliação Postural (SAPO), este obtém através de fotografias uma série de medidas relevantes $^{12}$. O software foi utilizado em um estudo recente de Yi et al (2008) ${ }^{13}$ que avaliaram 52 crianças de 5 a 12 anos de ambos os sexos, com objetivo de analisar as curvaturas da coluna vertebral.

O objetivo da fisioterapia consistirá em modificar ou adaptar movimentos, estimulando o desenvolvimento motor proporcionando assim, organização do sistema perante a maturação a partir da neuroplasticidade, na qual favorecerá a uma reorganização cerebral ${ }^{14}$. O tratamento fisioterapêutico deverá ser preciso de acordo com os acometimentos motores decorrentes da lesão cortical, por isso faz-se necessário estimular inputs sensoriais adequados, proporcionando a sensação da atividade de movimento, visando uma resposta adequada com a integração do sistema nervoso e sua estimulação prática ${ }^{15}$.

A dança inclusiva é uma alternativa terapêutica que visa minimizar estas dificuldades bem como promover melhora no controle postural e, portanto melhora de movimentos durante a marcha. Suas limitações não são objetos de rejeição, mas sim de um processo adaptativo e de parâmetro frutífero ${ }^{16}$. A possibilidade de aplicação da dança como instrumento terapêutico foi verificado ao ser constatado a melhora na qualidade de vida de uma paciente com paraplegia ${ }^{17}$. A necessidade em que o indivíduo tem de relacionar-se com o meio e com o seu próximo nos demonstra a idéia primitiva de que quando o movimento não for mais confortante, somos deficientes. Esta dificuldade pode desestimular quem a possui e desestruturar o restante que ainda reage naturalmente ${ }^{16}$.

O objetivo deste trabalho foi verificar possíveis melhoras no controle postural através da análise do centro de pressão da base de sustentação e marcha de uma criança com sequela de paralisia cerebral do tipo diparética espástica através dos instrumentos GMFM e SAPO após um protocolo com dança.

\section{MATERIAIS E MÉTODOS}

Para a seleção da participante do estudo foram utilizados os seguintes critérios de inclusão: gostar de dança, a assinatura do termo consentimento livre e esclarecido pelos responsáveis, ter idade igual ou superior a 10 anos e apresentar sequela de PC do tipo diparética espástica. Os critérios de exclusão foram ter sido submetido à cirurgia ortopédica e ao tratamento com toxina botulínica nos últimos 6 meses. Ao serem analisados todos os critérios acima descritos, somente uma criança estava apta a participar da pesquisa, sendo esta do sexo feminino, 12 anos e com diagnóstico de paralisia cerebral diparética espástica moderada. A pesquisa foi aprovada pelo comitê de ética da Universidade Estadual do Oeste do Paraná (Unioeste) com o parecer número 314/2007-CEP.

A criança foi avaliada antes e após o protocolo de dança para verificar prejuízos posturais, e melhorias no controle postural após terapia. Inicialmente a avaliação postural foi realizada com o auxílio de fotografias, estando a criança em uma postura em vista sagital e em outra em vista frontal. Marcadores de isopor com adesivos dupla face foram preparados para a marcação de pontos anatômicos: trágus da orelha, acrômio, sétima vértebra cervical, primeira vértebra lombar, espinha ilíaca ântero-superior, trocânter maior do fêmur, linha articular dos joelhos, ponto medial da patela, maléolo medial e lateral. A criança foi fotografada, utilizando trajes de ginástica, descalça com os pés unidos, e os cabelos presos para permitir a visualização da região cervical. Como a criança apresentava dificuldade em se manter na postura ortostática, a mesma, teve apoio de uma cadeira e foi orientada a manter os olhos abertos e visualizando o horizonte. Durante a avaliação postural, não houve o comando verbal para a correção postural. Foi colocado um fio de prumo próximo da criança. Para avaliação do tratamento foi utilizado um software de análise postural (SAPO) que a partir de pontos anatômicos verifica o alinhamento dos segmentos corporais, projeção do centro de gravidade na base de sustentação e fornece informações sobre o controle postural ${ }^{13,18}$. 
Também foi utilizada como instrumento de avaliação, a escala Gross Motor Function Measure (GMFM) ${ }^{19}$, que tem como objetivo avaliar a função motora grossa, até o ponto ao qual a criança pode realizar uma determinada atividade. Consiste em 85 itens de mesmo peso, agrupados em oito dimensões (supino, prono, quatro apoios, sedestação, ajoelhado, bipedestação, marcha e subida/descida). Estes itens são subdivididos em dimensões, como: A (deitar e rolar), B (sentar), C (engatinhar e ajoelhar), D (ficar em pé), e E (andar, correr, e pular). Cada item é pontuado em uma escala de 0 a 3 pontos, sendo graduado 0 o indivíduo que não inicia o movimento; 1 aquele que inicia o movimento, mas não o completa (efetua menos de $10 \%$ do movimento); 2 aquele que efetua parcialmente o movimento (10\% a menos de $100 \%)$; e 3 aquele que realiza o movimento ou postura solicitada. A criança foi analisada apenas na dimensão E para verificar possíveis dificuldades e condições das funções. Esta escala avalia os aspectos quantitativos da motricidade grossa.

Para a utilização da GMFM foram necessários materiais, como: fita métrica, banco longo, fita adesiva para marcação do solo, escada com no mínimo de 4 degraus com corrimão; degrau de $15 \mathrm{~cm}$ de madeira; bola plástica com circunferência de $65 \mathrm{~cm}$, banco de madeira utilizado como obstáculo e bola suíça de $45 \mathrm{~cm}$ para a criança segurar no momento da marcha.

A dimensão E avalia os seguintes aspectos: andar de lado 5 passos a direita e esquerda, segurando em um banco grande; 10 passos a frente segurado pelas duas mãos; 10 passos para frente segurado por uma mão; andar para frente 10 passos sem apoio; andar para frente 10 passos, parar, girar $180^{\circ}$ e retornar; andar para frente 10 passos, carregando com as 2 mãos um objeto grande; andar para frente 10 passos entre 2 linhas paralelas e separadas em 20,32 cm; andar para frente em uma linha reta de 1,9 cm de largura; dar um passo sobre obstáculo (banco) colocado ao nível do joelho; correr 4,57 m, parar e retornar; chutar a bola inicialmente com pé direito e depois esquerdo; pular $30 \mathrm{~cm}$ com ambos os pés; pular à frente $30 \mathrm{~cm}$ com ambos os pés simultaneamente; pular sobre o pé direito e depois com esquerdo 10 vezes dentro de um círculo; subir e depois descer 4 degraus com pés alternados, segurando corrimão e posteriormente sem segurar o corrimão; subir um degrau de $15 \mathrm{~cm}$ e pular com ambos os pés.

A paciente foi submetida a um plano de tratamento através de um protocolo de dança com terapias semanais. Previamente nas terapias foram realizados exercícios de alongamento para membros inferiores adutores, rotadores internos, extensores de coxa, flexores de quadril e tríceps sural e fortalecimento para diferentes grupos musculares como abdutores, flexores de coxa e foram baseadas em inserção à musicalidade, expressão corporal e, por conseguinte, movimentos de dança. As terapias tiveram duração de aproximadamente 45 minutos duas vezes por semana durante seis meses e foram realizadas na clínica de Fisioterapia da Unioeste. $\mathrm{O}$ tratamento ocorreu entre os meses de abril a outubro do ano de 2007, totalizando 52 atendimentos.

\section{RESULTADOSE DISCUSSÃO}

O software SAPO forneceu os resultados a partir da análise das imagens fotográficas. $\mathrm{O}$ relatório gerado ofereceu informações a cerca da projeção do centro de gravidade (CG), localização dos acidentes anatômicos marcados e suas variações e uma planilha completa com as coordenadas cartesianas dos pontos marcados pelo protocolo SAPO. Os resultados da posição da projeção do CG fornecidos pelo SAPO antes e após terapia e dados clínicos do sujeito são descritos em figuras. Na figura 1, o ponto de projeção do CG encontra-se fora do quadrante, anteriormente e para a direita.

Figura 1 - Resultados da avaliação: dados clínicos e projeção do centro de gravidade antes da terapia com dança.

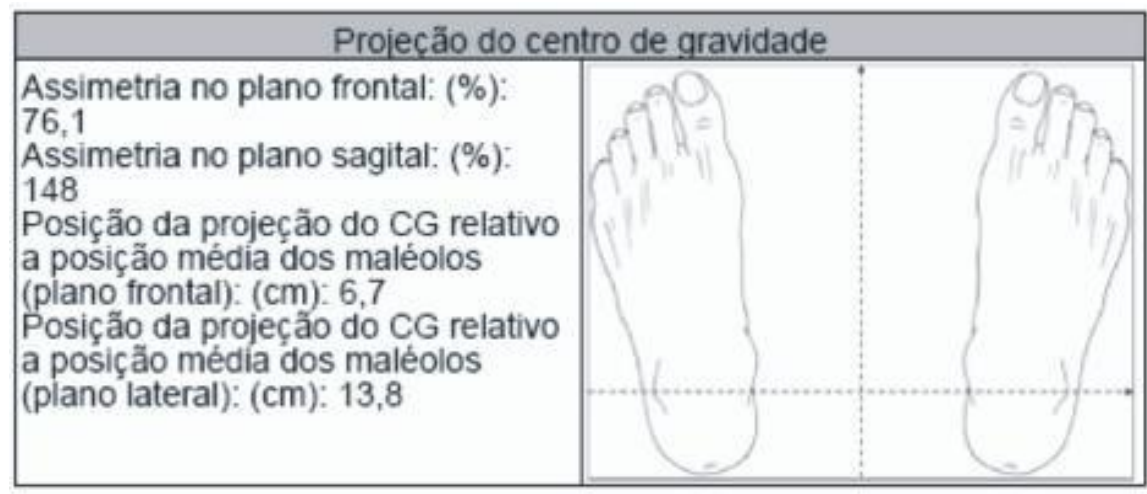

A próxima figura ilustra a mudança postural da criança após a realização do protocolo de dança, através da projeção do CG. 
Figura 2 - Resultados da avaliação: dados clínicos e projeção do centro de gravidade depois da terapia com dança.

\begin{tabular}{|l|l|}
\hline \multicolumn{2}{|c|}{ Projeção do centro de gravidade } \\
\hline Assimetria no plano frontal: (\%): \\
30,4 \\
Assimetria no plano sagital: (\%): \\
130,5 \\
Posição da projeção do CG relativo \\
a posição média dos maléolos \\
(plano frontal): (cm): 2,2 \\
Posição da projeçấo do CG relativo \\
a posição média dos maléolos \\
(plano lateral): (cm): 9,3
\end{tabular}

A partir da análise das imagens fotográficas, o relatório gerado pelo programa ofereceu resultados sobre o centro de gravidade da criança obtendo assimetria no plano frontal antes da intervenção, de $76,1 \%(6,7 \mathrm{~cm})$ e após intervenção, $30,4 \%$ (2,2cm); e no plano sagital, antes do tratamento, de $148 \%(13,8 \mathrm{~cm})$ e após tratamento, de $130,5 \%$ (9,3cm). Demonstrando que antes da intervenção pelo protocolo de dança, a criança apresentava uma anteriorização e assimetria inadequadas, resultado de uma alteração postural. E após a intervenção houve uma diminuição da anteriorização do $\mathrm{CG}$.

A figura 3 apresenta a avaliação postural realizada pelo software SAPO, antes do início do protocolo de dança, realizada no dia 08 de abril de 2007. A data na figura está representada como dia 18 de outubro de 2007, pois foi nesta data em que as fotografias foram analisadas pelo software.

Figura 3 - Avaliação Postural vista anterior, lateral esquerda antes da terapia com dança.

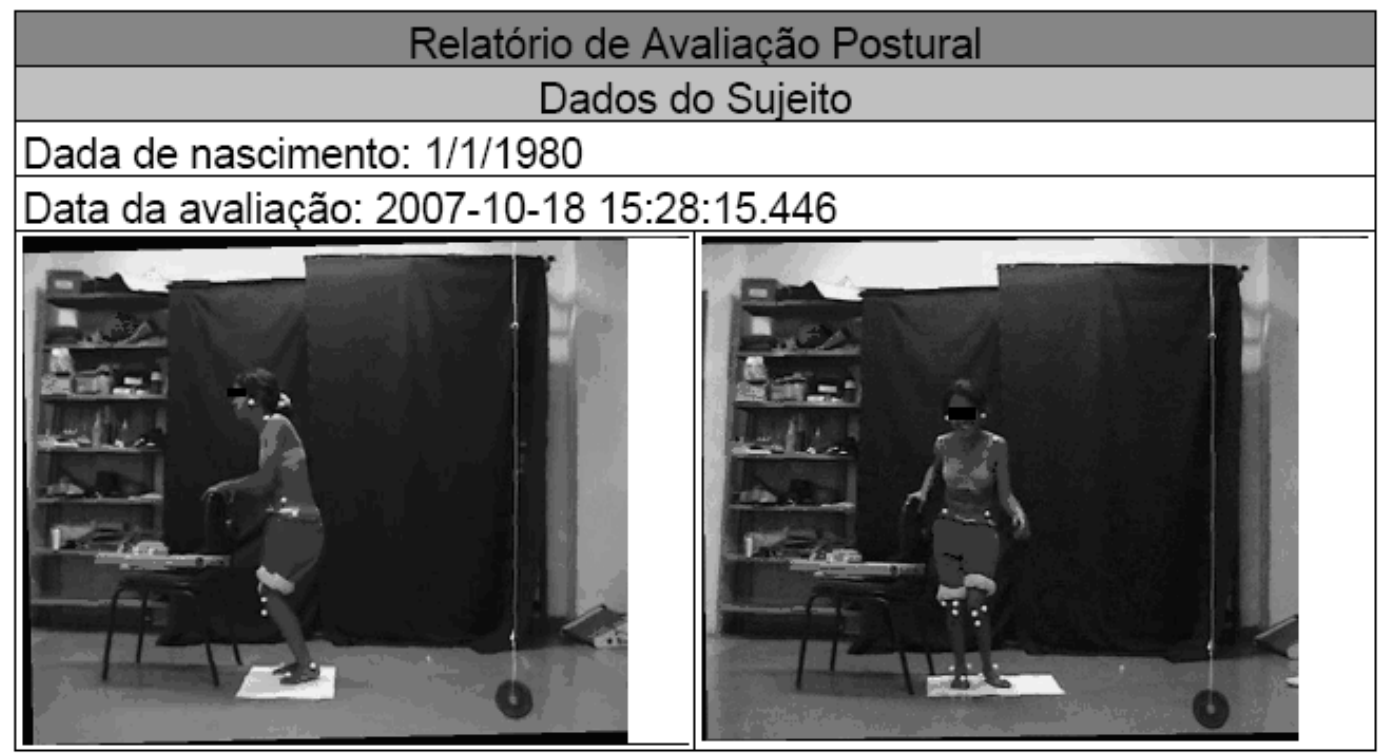

A próxima figura ilustra a avaliação postural da criança após a realização do protocolo da dança. Sendo esta realizada no dia 10 de outubro de 2007. 
Figura 4 - Avaliação Postural vista anterior, lateral esquerda, lateral direita e posterior após terapia com dança.

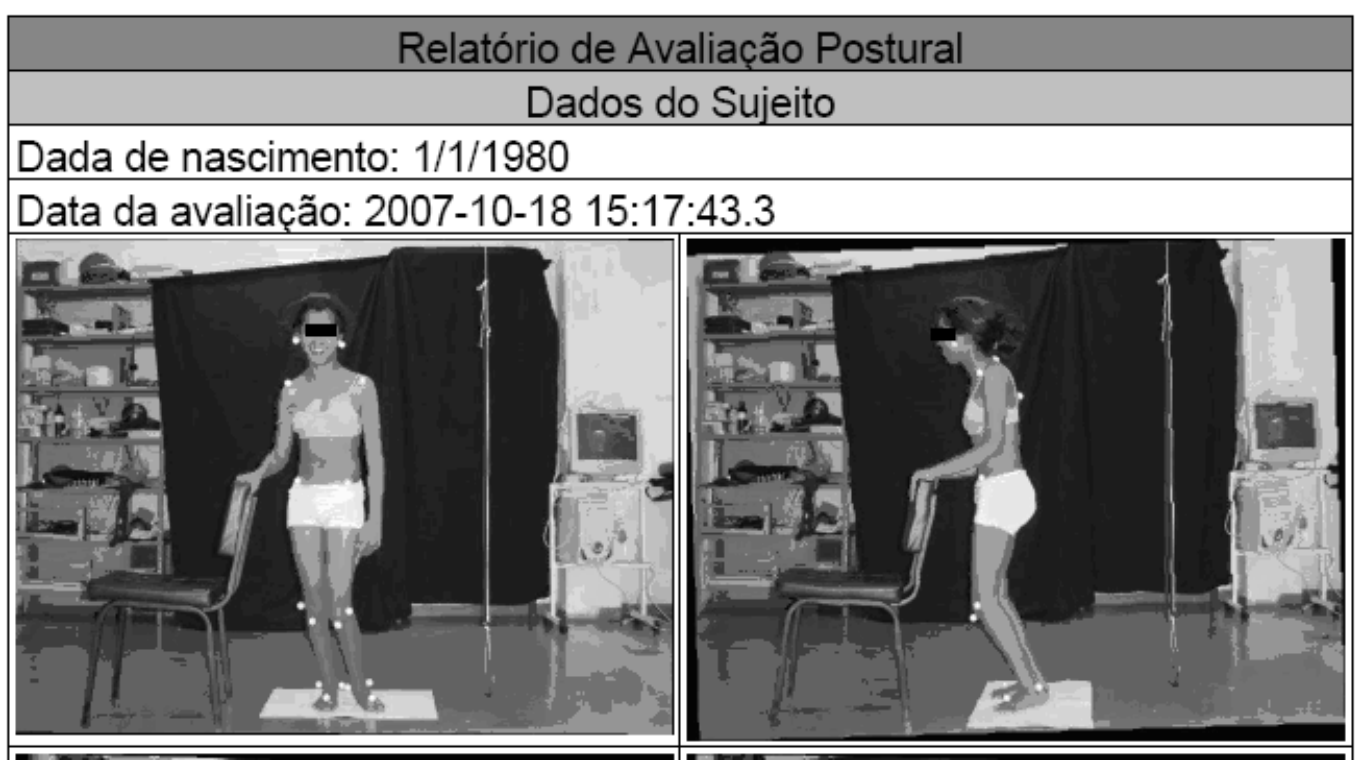

$\mathrm{Na}$ análise do alinhamento postural, no final do protocolo de dança, verificado através da figura 3, observou-se melhora no posicionamento da cabeça e melhor endireitamento do tronco.

Na avaliação através da pontuação da escala GMFM, na subdivisão E correspondente a marcha, os resultados obtidos podem ser vistos no gráfico 1.

Gráfico 1 - Pontuação obtida na dimensão E através da Escala GMFM, na avaliação pré e pós terapia com dança.

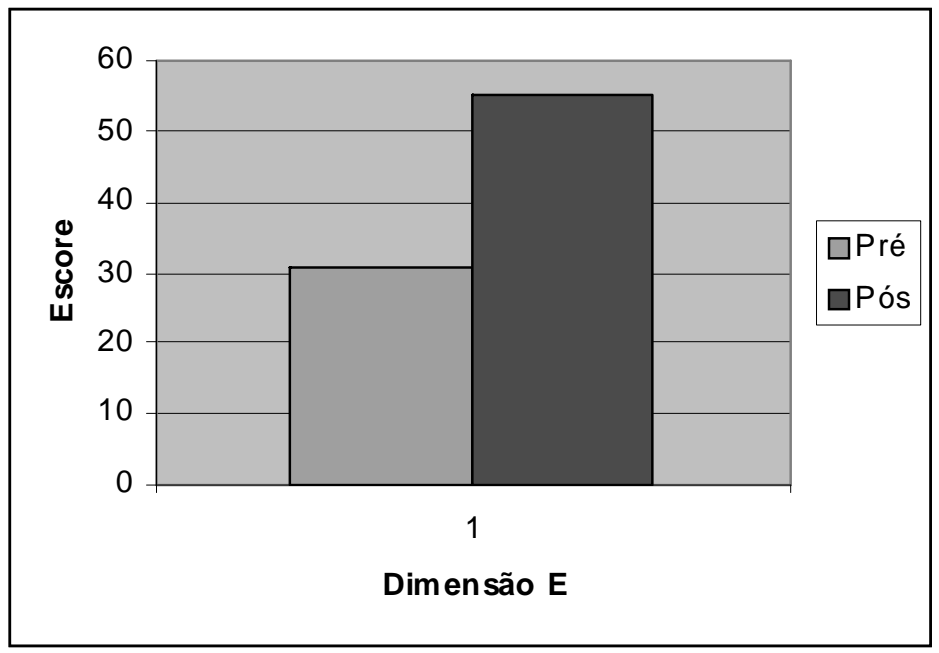

No gráfico 1 observa-se que a pontuação total obtida no final da terapia foi maior, demonstrando o crescente desempenho da criança.

Dentre as atividades que obtiveram melhora no desempenho segundo o GMFM temos: andar para frente 10 passos, parar, girar 180 graus e retornar, andar para trás 10 passos, andar para frente 10 passos (entre linhas separadas por 20,32 cm e uma linha reta de 1,9 cm largura), superar obstáculo ao nível do joelho, correr 4,57 m e retornar, chutar bola, pular $30 \mathrm{~cm}$ de altura, pular dentro de um círculo 10 vezes, subir e descer degraus com pés alternados e pular sobre um degrau com os dois pés simultâneos.

A avaliação postural realizada com a criança participante do estudo é uma ferramenta fundamental no diagnóstico do alinhamento dos segmentos corporais e constitui-se no passo inicial para avaliação e tratamento, influenciando a conduta 
terapêutica ${ }^{18}$.

De acordo com o software SAPO, a forma mais objetiva e fidedigna de avaliação postural consiste no registro de fotografias do corpo inteiro do indivíduo em diferentes planos e posturas e então análise da posição relativa de referências anatômicas dos segmentos corporais ${ }^{18}$.

Sacco et al $(2007)^{20}$ realizaram um estudo que utilizou o SAPO para avaliar voluntários com idade entre 18 e 54 anos, e tiveram como objetivo verificar a confiabilidade do software. Esta confiabilidade foi confirmada, demonstrando que o SAPO é adequado para análise quantitativa do alinhamento postural.

A postura de uma criança com paralisia cerebral do tipo diparesia, usualmente, apresenta flexão de quadris e joelhos, adução de membros inferiores e, inversão de tornozelos. Há também um comprometimento do tronco, este pode permanecer em cifose dorsal. Nesta situação a criança apresenta dificuldade em permanecer em alinhamento, dificultando assim, a manutenção adequada do centro de gravidade e controle postural ${ }^{5}$. Justificando, dessa forma, a avaliação postural utilizada neste estudo.

Na segunda avaliação foi utilizada a GMFM que auxilia na observação de aquisições das habilidades motoras grossas em crianças com PC, sendo um instrumento de planejamento para o tratamento fisioterapêutico a se realizar, servindo como guia para reavaliação, mostrando as habilidades motoras adquiridas e auxiliando na reestruturação de terapias ${ }^{21}$.

$\mathrm{Na}$ pesquisa coordenado por Kelly et al (2008) ${ }^{23}$ a GMFM e outras escalas de avaliação foram utilizados para avaliar e reavaliar 19 crianças com PC após o uso de toxina botulínica. De acordo com os resultados obtidos, a GMFM, juntamente com Modified Ashworth Scale (MAS) e Modified Tardieu Scale (MTS) foram consideradas como escalas de avaliação de moderada para excelente.

Em outro estudo ${ }^{22}$ foram avaliados 5 sujeitos com seqüela de PC do tipo diparética, na faixa etária entre 4 a 9 anos e observaram que as funções mais deficitárias foram as atividades nas posições em pé e andar, correr e pular. Assim como nesta pesquisa, a paciente do estudo apresentou dificuldade de realização destas tarefas durante a avaliação da GMFM.

Em um estudo de caso realizado por Correa e Paula (2007) ${ }^{24}$ obtiveram uma pequena evolução dos desempenhos nas atividades motoras grossas através da utilização da dança como atividade terapêutica com crianças com sequela de PC.

Entre as atividades motoras grossas, a marcha exige estabilidade, mobilidade para movimentos suaves e controle motor. Diferentes aspectos biomecânicos são empregados durante a marcha, como: excursão mínima do centro de gravidade e movimentos sincronizados do tronco, pelve, quadris, joelhos, tornozelos e pés ${ }^{25}$. Situações em que há prejuízo motor como na paralisia cerebral, a criança apresenta um maior gasto energético e ações compensatórias ${ }^{26}$. A criança participante do estudo obteve melhora da marcha, como foi demonstrada pela GMFM e isto pode ser justificado através da melhor projeção do centro de gravidade, que como citado, influencia no desempenho da marcha.
A criança com paralisia cerebral do tipo diparética apresenta espasticidade, encurtamento e fraqueza em alguns grupos musculares de membros inferiores, abdominais e dos para-vertebrais ${ }^{5}$. Sendo assim, exercícios de alongamento e fortalecimento para membros inferiores e tronco, poderão levar a criança a ter maior controle postural, uma melhora na base de apoio e de atividades funcionais, como a marcha ${ }^{1}$, objetivo mencionado pelo protocolo de dança em que a criança do estudo foi submetida.

Estudos demonstraram a eficiência de um protocolo de dança no auxílio da qualidade de vida de crianças com paralisia cerebral.

Couper, J. ${ }^{27}$ em seu estudo realizado com 5 crianças que apresentaram prejuízo motor utilizou a dançaterapia durante 4 semanas. A conclusão obtida pela pesquisa foi a melhora da performance motora em um curto período.

Cinco participantes do sexo feminino com seqüela de paralisia cerebral participaram de um protocolo de dança terapêutica e apresentaram evolução do equilíbrio estático e dinâmico, como também da coordenação motora grossa ${ }^{28}$.

Em outro estudo, quatro indivíduos com diagnóstico de paralisia grave ou moderada, do sexo feminino, na faixa etária de 10 a 15 anos participaram de aulas semanais de dança. No desenvolvimento motor, verificaram-se melhoras nas atividades que exigiam a execuçäo de movimentos simétricos ou dissociados de membros superiores. Também notou-se maior independência nas atividades de vida diária ${ }^{29}$.

\section{CONCLUSÃO}

O protocolo de dança mostrou-se eficiente na reabilitação da paciente com sequiela de paralisia cerebral do tipo diparética espástica. O protocolo foi capaz de auxiliar na reabilitação motora, a curto prazo, da paciente representada pela evolução de habilidades motoras grossas e em um melhor controle postural.

\section{REFERÊNCIAS BIBLIOGRÁFICAS}

1. Shepherd RB. Fisioterapia em Pediatria. 3 ed. São Paulo: Ed. Santos, 2002.

2. Leite JMR S; Prado GF. Paralisia cerebral aspectos fisioterapêuticos e clínicos. Revista de Neurociências 2004;12, (1):41-46

3. Iwabe C; Piovesana AMSG. Investigação das causas do atraso no neurodesenvolvimento. Arquivos de Neuropsiquiatria 2003; 61(3): 617-620.

4. Mancini MC; Fiúza PM; Rebelo JM; Magalhães LC; Coelho ZAC; Paixão ML; Gontijo APB; Fonseca ST. Comparação de desempenho de atividades funcionais em crianças com 
desenvolvimento normal e crianças com paralisia cerebral. Arquivos de Neuropsiquiatria 2002; 60 (2): 446-452.

5. Bobath B; Bobath K. Desenvolvimento Motor dos Diferentes Tipos de Paralisia Cerebral. São Paulo: Ed Manole, 1989.

6. Miller G; Clark GD. Paralisias Cerebrais. São Paulo: Ed. Manole, 2002.

7. Rosa GKB; Marques I; Medina-Papst J; Lilian Teresa Bucken Gobbi, L TB. Desenvolvimento motor de criança com paralisia cerebral: avaliação e intervenção. Rev. Bras. Educ. Espec., $2008 ; 14(2)$.

8. Russell DJ; Rosebaum PL; Cadman DT; Gowland C; Hardy S; Jarvis S. The Gross Motor Function Measure: A Means to Evaluate the Effects of Physical Therapy. Dev Med Child Neurol, 1989; 31:34152.

9. Durigon O F; Sá CSS; Sitta LV. Validação de um protocolo de avaliação do tono muscular e atividades funcionais para crianças com paralisia cerebral. Rev. Neurociências 2004; 12: 171-177.

10. Chagas PSC; Defilipo EC; Lemos RA; Mancini MC; Frônio JS; Carvalho RM. Classificação da função motora e do desempenho funcional de crianças com paralisia cerebral. Rev. bras. fisioter. 2008; 12 (5).

11. Casady RL; Nichols-Larsen DS. The effect of hippotherapy on ten children with cerebral palsy. Pediatr Phys Ther; 2004;16(3): 165-72.

12. Rech I. Albuquerque CE. Avaliação Postural em Hemiplégicos, proposta de aplicação do software SAPO: estudo piloto. Trabalho de Conclusão de Curso - Universidade Estadual do Oeste do Paraná, Cascavel, 2006.

13. Liu Chiao Yi, José R. Jardim Daniel Paganini Inoue, Shirley SN. Pignatari. Relação entre a excursão do músculo diafragma e as curvaturas da coluna vertebral em crianças respiradoras bucais. Jornal de Pediatria 2008; 84(2):171-177.

14. Rose J; Wolff DR; JonesVK; Bloch DA; Oehlert TJW; Gamble JG; Postural balance in children with cerebral palsy, Developmental medicine \& Child Neurology 2002; 44: 58-63.

15. Peixoto ES; Mazzitelli C. Avaliação dos Principais Déficits e Proposta de Tratamento da Aquisição Motora Rolar na Paralisia Cerebral. Revista Neurociências 2004; 2(1): 46-53.

16. Chianell J. Justificativa. Acadef - Associação Carioca de Deficiente Físico. 2002. http://www.acadef.org/justificativa.html. Acesso em 08 de mar. 2007.

17. Tessaro SM; Ide MR; Dançaterapia em pacientes com paraplegia: estudo de caso. Trabalho de Conclusão de Curso - Universidade
Estadual do Oeste do Paraná, Cascavel, 2006.

18. Portal do projeto software para avaliação postural. http:// sapo.incubadora.fapesp.br/portal. Acesso em 23 de abr. de 2007. 19. Pina Luciana Ventura de; Loureiro Ana Paula Cunha. O GMFM e sua aplicação na avaliação motora de crianças com paralisia cerebral. Fisioter. mov. 2006; 19(2):91-100.

20. Sacco ICN; Alibert S; Queiroz BWC; Pripas D; Kieling I; Kimura AA; Sellmer AE.; Malvestio RA; Será MT. Confiabilidade da fotogrametria em relação a goniometria para avaliação postural de membros inferiores. Rev. Bras. Fisiot. 2007, 11(5). 21. Paschoaletti AL; Gaetan ESM; Natalício F; Duarte GC; Silva KF; Petroni TF. Avaliação da função motora grossa em crianças com paralisia cerebral por meio da GMFM-88. Revista Estação, $20064(6)$.

22. II INTER COBRAF, 3.; 2006, Santos. Anais Análise da função motora, através do GMFM-66, em crianças com paralisia cerebral diparética. Iwabe EC; Barudy DP; Kempe J; Prada RM; Deloroso MGB; Unglauber E; Correa PR, Santos, 2006.

23. Kelly B; Mackay-Lyons M j; Berryman S; Hyndman J; Wood E. Assessment protocol for serial casting after botulinum toxin a injections to treat equines gait. Pediatr Phys Ther, 20 (3): 233-241, 2008.

24. CONGRESSO DE INICIAÇÃO CIENTÍFICA DA UFSCAR, 15., 2007, São Carlos. Anais Possibilidades de Intervenção Hidroterápica lúdica no tratamento de crianças com paralisia cerebral: Um estudo de caso., Correa, M.F.; Paula, L.C. São Carlos: UFSCar, 2007.

25. Rose J; Gamble J. Marcha humana. 2 ed. São Paulo: Ed. Premier, 1998.

26. Souza AMC; Ferraretto I. Paralisia Cerebral: aspectos práticos. São Paulo: Ed. Memnon, 1998.

27. Couper JL. Dance therapy: effects on motor performance of children with learning disabilities. Phys Ther. v. 61, n. 1, p. 23-26, 1981.

28. Guimarães EL; Santana JM; Guimarães, E. L. Aplicabilidade da dança terapêutica para recuperação funcional de portadores de distúrbios percepto-motores. www.fafibe.br/revistaonline/ arquivos/elaine-aplicabilidadedadancaterapeuticaparar.pdf acesso em abril de 2009.

29. Braccialli LM; Presumid R; Rosalina M; Q. Dança: influência no desenvolvimento da criança com paralisia cerebral. Temas desenvolv; 7(38):22-5, 1998.

Endereço para correspondência:

Aneline Maria Ruedell

Rua Pinheiro Machado, 2866/302

97050-600 Santa Maria RS - Brasil

Fone: 3026-8268. E-mail: aneruedell@yahoo.com.br 


\title{
MEDICAMENTOSANOREXÍGENOS - PANORAMA DA DISPENSAÇÃO EM
} FARMÁCIAS COMERCIAIS DE SANTA MARIA(RS)

\author{
Anorectic Drugs - panorama dispensation in commercial drugstores of Santa Maria (RS)
}

\begin{abstract}
Andrieli Cassel Feltrin ${ }^{l}$, Graziela Zordan ${ }^{l}$, Fernanda Wagner ${ }^{l}$,Gabriela Cristina Schmitt ${ }^{l}$, Aline Augusti Boligon ${ }^{2}$, Naiane Delamolle, Margareth Linde Athayde e Lauren Crossetti Vaucher
\end{abstract}

\begin{abstract}
RESUMO
O presente trabalho foi objetivado na obtenção de informações sobre a dispensação de medicamentos anorexígenos em farmácias comerciais de Santa Maria e a comparação com estudo anterior realizado no ano de 2002. A avaliação sobre a venda de medicamentos anorexígenos abrangeu os meses de setembro de 2006 a fevereiro de 2007, sendo visitados 13 estabelecimentos da região central do município. Foram analisadas 722 receitas, totalizando 1426 medicamentos desta classe dispensados. Os resultados mostraram que o princípio ativo mais dispensado foi o femproporex $(53,09 \%)$. A especialidade médica que mais prescreveu foi os clínicos gerais com $76,45 \%$ e os maiores consumidores foram indivíduos do sexo feminino $(93,35 \%)$.

Palavras chave: anorexígenos; obesidade; Santa Maria - RS.

\section{SUMMARY}

The present paper aimed to obtain information on the dispensation of anorectic drugs in commercial drugstores of Santa Maria and to compare this with previous study accomplished in the year of 2002. The evaluation on the sale of anorectic drugs included the months of September of 2006 to February of 2007, being 13 establishments, of the central area of the municipal district, visited. Seven hundred and twenty-two prescriptions were analyzed, with a total of 1426 medicines from class released. The results showed that the more released active principle was the femproporex $(53,09 \%)$. The medical specialty that more prescribed was the general practitioners with $76,45 \%$ and the largest consumers were female individuals $(93,35 \%)$.

Keywords: anorectic; obesity; Santa Maria - RS.
\end{abstract}

\section{INTRODUÇ̃̃}

A obesidade é um dos principais problemas que a área da saúde enfrenta atualmente. Segundo estatísticas da Organização Mundial da Saúde (OMS), calcula-se que cerca de $25 \%$ da população mundial é obesa e que destes, $25 \%$ morrem por conseqüências diretas ou indiretas da obesidade ${ }^{1}$. Esta doença esta intimamente relacionada a um aumento na incidência de alterações cardiovasculares, hiperlipidemia, hipertensão arterial sistêmica, diabetes, entre outras. A alta prevalência e a importância das comorbidades fazem com que a obesidade seja considerada uma das mais importantes doenças nutricionais do mundo ocidental ${ }^{2}$.

A primeira droga utilizada com o propósito de emagrecimento foi a anfetamina. Com o tempo, a anfetamina foi entrando em desuso por causar tolerância e dependência entre os pacientes. Além disso, a perda de peso era temporária e os pacientes não conseguiam manter o peso com a suspensão do tratamento ${ }^{3}$. Modificações na estrutura química da anfetamina (a-metil :sanfetamina) levaram à síntese de uma gama de compostos, com ações e respostas farmacológicas variadas para o tratamento da obesidade. Os derivados :5-fenetilamínicos demonstraram um ação redutora da ingestão de alimentos em estudos em animais, sendo esta ação o mecanismo primário de indução da perda de peso. A perda de peso relaciona-se com o fato dessas drogas apresentarem um aumento nas monoaminas

Trabalho realizado no Departamento de Farmácia Industrial da Universidade Federal de Santa Maria (UFSM) /RS

${ }^{1}$ Acadêmica formada no curso de Farmácia da UFSM

${ }^{2}$ Aluna do Curso de Pós - Graduação em Ciências Farmacêuticas da UFSM

${ }^{3}$ Prof ${ }^{a}$. Adjunta da UFSM 
do Sistema Nervoso Central (SNC), principalmente no hipotálamo. No entanto, efeitos adversos comuns à anfetamina ainda podem ser encontrados ${ }^{4}$.

Atualmente, existem no mundo 14 tipos de moderadores de apetite regulamentados e geralmente prescritos no tratamento da obesidade, conforme convenções internacionais. Na maioria dos países eles só podem ser comprados com receitas médicas, bastante controladas, pois se tomados em doses elevadas podem causar alucinações e problemas cardiorespiratórios, entre outros efeitos ${ }^{5}$.

Os medicamentos anorexígenos são fármacos usados para o tratamento da obesidade nos casos em que o Índice de Massa Corporal for maior ou igual a 30 , ou maior ou igual a 25 se estiver acompanhado de fatores de risco. O preocupante é que muitas vezes essas medicações são prescritas sem um programa concomitante de dieta e exercício, e nesta situação somente os medicamentos dificilmente são eficazes, uma vez que o paciente perde vários quilos durante o uso de medicação, mas assim que interromper o uso voltará seu peso inicial ou até mais, caso não tenha melhorado seus hábitos de alimentação e atividade física4,6.

Considerando a importância do controle no uso de medicamentos anorexígenos, o presente trabalho foi objetivado na obtenção de informações atuais sobre a dispensação desta classe de medicamentos em farmácias comerciais de Santa Maria e a comparação com um estudo anterior realizado no período de julho a dezembro de $2002^{6}$.

\section{MATERIAS E MÉTODOS}

A avaliação sobre a venda de medicamentos anorexígenos na cidade de Santa Maria abrangeu os meses de setembro de 2006 a fevereiro de 2007, sendo visitados 13 estabelecimentos da região central do município. Este estudo foi realizado através de consultas aos receituários e livros de registro de medicamentos controlados. Essas substâncias pertencem à classe de medicamentos controlados pela Portaria $344 / 98^{7}$, fazendo parte dos receituários da lista B2, de cor azul, sendo referidos como psicotrópicos anorexígenos.

Portanto, para se ter acesso às receitas, foi redigido um ofício assinado pela orientadora do trabalho ao farmacêutico responsável pela farmácia comercial, pedindo a colaboração do mesmo para a concretização da referente pesquisa. Este documento continha os dados da pesquisadora, o objetivo do estudo e sua finalidade, assim como a informação sobre o comprometimento em manter sigilo absoluto sobre a identificação da origem dos dados obtidos, ou seja, nomes de pacientes, estabelecimentos, farmacêuticos, e médicos.

Nas receitas e livros de registro, verificou-se o nome do medicamento, o princípio ativo e a quantidade prescrita, o sexo do paciente, o mês referente à venda do medicamento e a especialidade médica que estava prescrevendo.

Foram analisadas 722 receitas, totalizando 1426 medicamentos anorexígenos dispensados nos meses referentes à pesquisa.

\section{RESULTADOSE DISCUSSÃO}

No presente estudo, observou-se que do total de medicamentos vendidos neste período, com relação à dispensação pelo seu nome comercial, com 53,09\% (757) corresponde ao Desobesi-M, cujo princípio ativo é o femproporex, 15,92\% (227) ao Fagolipo, 13,04\% (186) ao Dualid S, 8,91\% (127) ao Inibex S, 5,47\% (78) ao Hipofagin $\mathrm{S}, 2,87 \%$ (41) ao Cloridrato de anfepramona $75 \mathrm{mg}$ e por fim 0,70\% (10) ao Absten S (Figura 1). Assim o medicamento com maior percentual de dispensação, nos estabelecimentos analisados, de acordo com seu princípio ativo foi o femproporex com 53,09\% (757), 30,29\% (432) contendo anfepramona e 16,62\% (237) contendo mazindol (figura 2).

Figura 1 - Distribuição percentual de medicamentos anorexígenos vendido nos estabelecimentos farmacêuticos analisados no período de setembro de 2006 a fevereiro de 2007, de acordo com seu nome comercial.

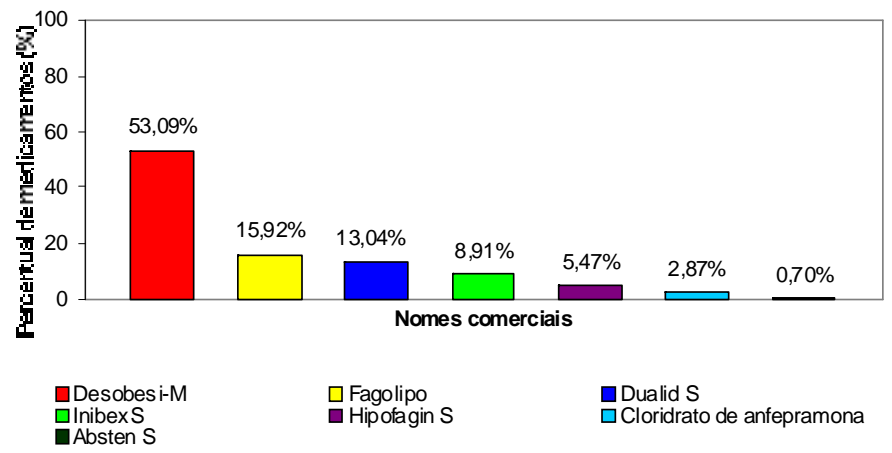


Figura 2 - Distribuição percentual de medicamentos anorexígenos vendido nos estabelecimentos farmacêuticos analisados no período de setembro de 2006 a fevereiro de 2007, de acordo com o princípio ativo.

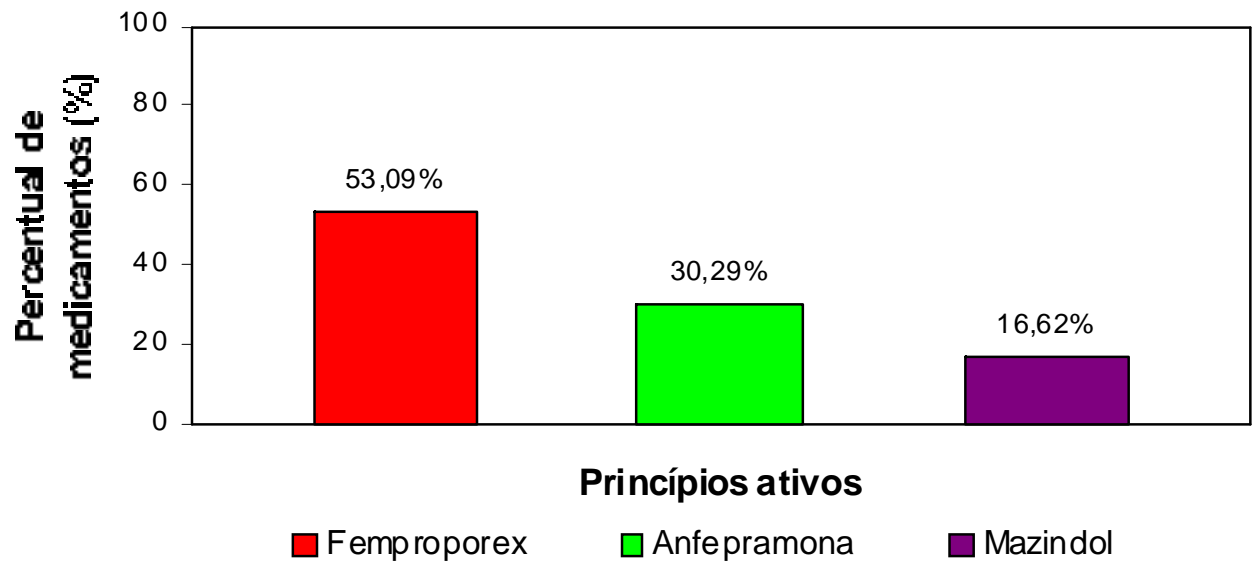

Com relação aos meses do ano, o mês de novembro de 2006 apresentou a maior quantidade de medicamentos dispensados, alcançando um percentual de $20,69 \%$ do total de 1426 medicamentos, seguido pelos meses de outubro de $2006(17,67 \%)$, dezembro de 2006 (17,32\%), janeiro de 2007 (15,71\%), setembro de $2006(14,80 \%)$ e por último o mês de fevereiro de 2007 que apresentou o menor percentual de vendas (13,81\%) (figura 3 ).
Esses resultados mostram que com a proximidade do verão, a procura por este tipo de medicamento aumenta. Isso se deve ao fato de que há uma maior preocupação com a aparência física, devido a maior exposição do corpo neste período do ano. Na maioria das vezes, estes fármacos são utilizados por pessoas que não se enquadram no perfil necessário para o uso deste tipo de tratamento ${ }^{8}$.

Figura 3 - Distribuição percentual de medicamentos anorexígenos dispensados nas farmácias comerciais analisadas no período de setembro de 2006 a fevereiro de 2007.

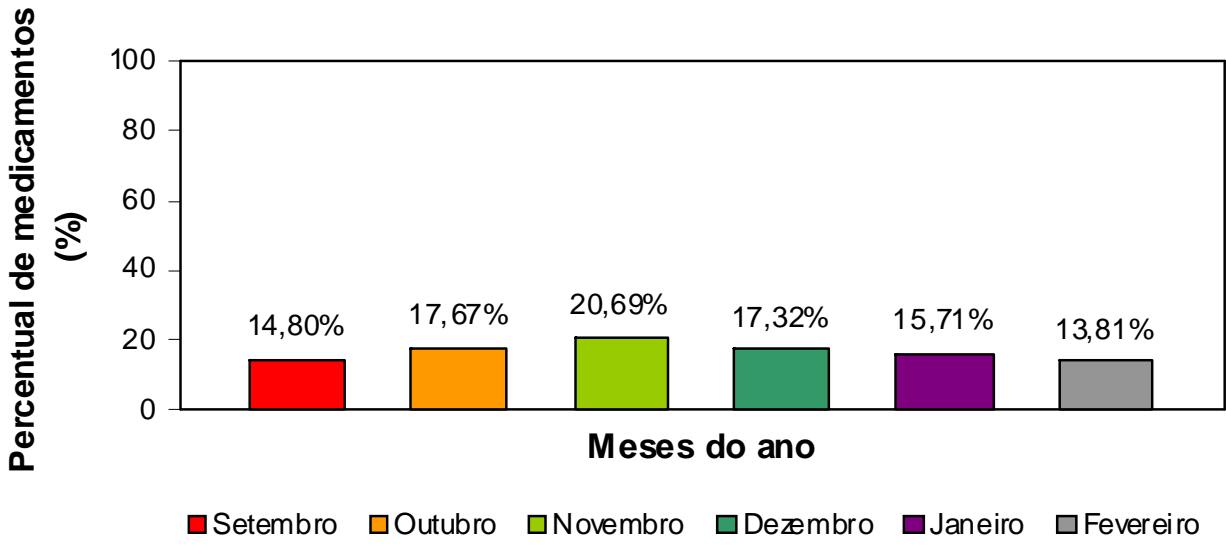

Analisando-se o sexo do paciente usuário destes medicamentos, observou-se que 93,35\% dos usuários eram do sexo feminino e apenas $6,65 \%$ eram pacientes do sexo masculino (figura 4). Este perfil reflete a realidade social, em que as mulheres procuram mais ajuda médica do que os homens, se preocupando mais com a saúde, bem-estar e também com a aparência. Uma vez que, o sinônimo de beleza feminina muitas vezes está relacionado ao baixo peso, cintura fina, estereotipo de topmodels conhecidas mundialmente ${ }^{9}$. 
Figura 4 - Distribuição percentual de receituários analisados nos estabelecimentos farmacêuticos entre setembro de 2006 a fevereiro de 2007, de acordo com o sexo do paciente usuário.

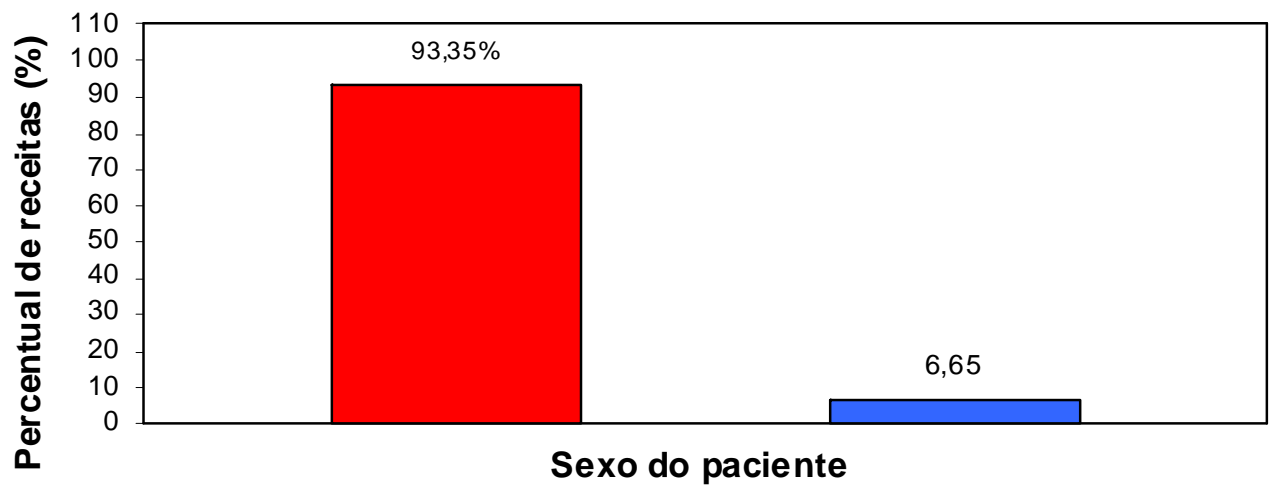

Feminino

$\square$ Masculino

A figura 5 mostra a distribuição da dispensação dos medicamentos anorexígenos relacionados com a especialidade médica prescritora. O maior número de receitas prescritas está relacionado com os clínicos gerais, equivalendo a 76,45\% do total, seguido pelos endocrinologistas $(6,51 \%)$, psiquiatras $(5,68 \%)$, ginecologistas $(5,26 \%)$, cirurgiões $(1,52 \%)$, outras especialidades médicas $(1,40 \%)$, médicos do trabalho $(1,11 \%)$ e reumatologistas e traumatologistas $(0,97 \%)$. Esse tipo de medicamento, para fins de perda de peso, deve ser prescrito por médicos endocrinologistas e especialidades relacionadas. Como observado na pesquisa, os médicos que mais receitam esses fármacos são os clínicos gerais, talvez devido ao maior acesso dos pacientes a estes médicos e também, pelo maior numero desses profissionais se comparado o de outras especialidades ${ }^{10}$.

Outra razão para o baixo percentual de receituários prescritos pelos médicos endocrinologistas deve-se ao aumento na prescrição de sibutramina, medicamento também utilizado como inibidor de apetite, agindo na inibição da recaptação de serotonina e noradrenalina, que apresenta boa eficácia na perda de peso e possui menores efeitos colaterais quando comparado com anorexígenos, não ocasionando dependência física. Além disso, com o fim da patente da sibutramina em dezembro de $2006 \mathrm{e}$ produção desse medicamento genérico, o produto tornou-se mais barato facilitando sua compra pelos pacientes.

A terceira especialidade médica, segundo a pesquisa, em números de receitas prescritas são os psiquiatras, devido ao fato que, muitas vezes a obesidade acaba desencadeando um estado depressivo no paciente, que é levado a procurar um médico para o tratamento adequado. Os ginecologistas estão em quarto lugar em prescrições de anorexígenos talvez porque grande parte das mulheres não está satisfeitas com o corpo, e na ocasião da consulta, expõem isso ao médico, ocasionando a indicação dessa classe de medicamentos. Observa-se num número significativo de outras especialidades, como reumatologistas, traumatologistas, cirurgiões, geriatras, pediatras, entre outras, receitando esse tipo de medicamento, mostrando que, mesmo sob orientação médica, esses fármacos não estão sendo utilizados de maneira adequada.

Figura 5 - Distribuição percentual de receituários analisados nas farmácias comerciais entre setembro de 2006 e fevereiro de 2007, de acordo com a especialidade médica prescritora.

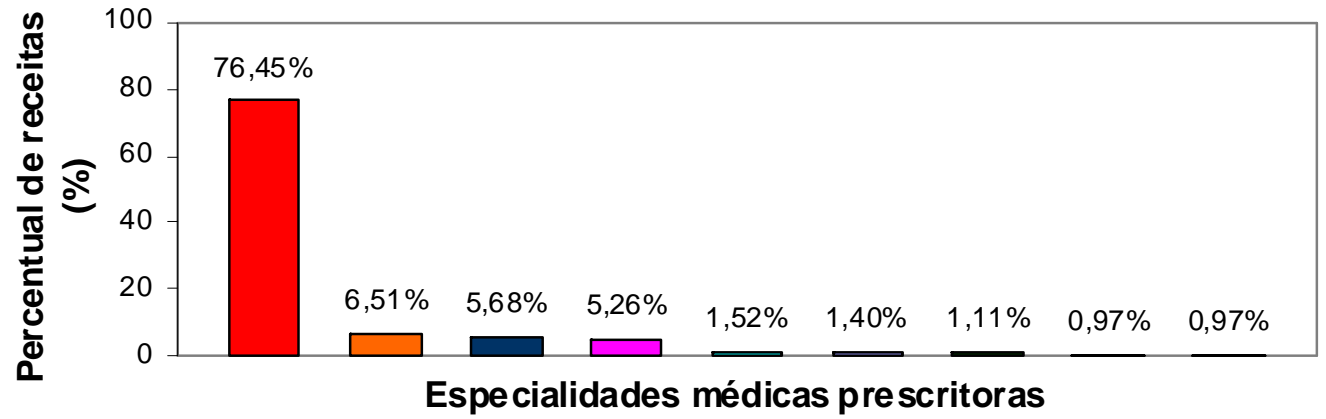

Clínico geral $\square$ Gine colog is ta -Médico do trabalho

\author{
$\square$ Endocrinologista \\ $\square$ Cirurgião \\ $\square$ Traumatologista
}

Psiquiatra

$\square$ Outras especialidades

$\square$ Reum atologis ta 
No período compreendido entre julho e dezembro de 2002, foi realizada uma pesquisa semelhante a esta, em farmácias comerciais de grandes redes privadas do centro da cidade de Santa Maria, objetivando avaliar a dispensação dos medicamentos anorexígenos levando em consideração os mesmos parâmetros abordados no presente trabalho ${ }^{6}$.

Na pesquisa realizada em 2002, o medicamento com maior percentual de venda também foi o Desobesi-M, apresentando um percentual de 40,8\% em relação ao total de 536 receitas analisadas, seguido pelo Hipofagin S 75mg (12,5\%), Inbex S $(9,7 \%)$, Dualid S $(6,1 \%)$, Fagolipo $(6 \%)$. Cloridrato de anfepramona $(2,6)$ e com o menor percentual o Absten $\mathrm{S}(1,1 \%)$, Sendo assim, o femproporex foi o fármaco mais dispensado no período de julho a dezembro de 2002, seguido pela anfepramona e por último o mazindol. O mês com maior porcentagem de vendas dos anorexígenos foi o mês de outubro $(24,8 \%)$, o percentual de pacientes usuários destes fármacos de acordo com o sexo foi $91,6 \%$ mulheres e $8,37 \%$ homens em relação ao total de receitas. A especialidade médica prescritora que apresentou maior percentual de receitas foram os clínicos gerais, com $49,1 \%$ do total de receitas ${ }^{6}$.

A figura 6 apresenta a comparação do perfil de dispensação de anorexígenos de acordo com seus nomes comerciais nos anos de 2002 e 2006-2007, onde pode ser observado um aumento da percentagem de dispensação dos fármacos Desobesi-M, Fagolipo, Dualid S e Cloridrato de anfepramona.

Comparando os dados obtidos nas duas pesquisas, percebe-se que, após cinco anos, os resultados encontrados não apresentam grandes mudanças, ocorrendo alterações referentes ao mês do ano com maior percentual de vendas, outubro em 2002 e novembro em 2006, porém permanecendo em épocas próximas ao verão. $\mathrm{O}$ medicamento mais vendido, Desobesi-M e seu principio ativo, o femproporex, assim como a especialidade médica prescritora com maior percentual de receitas e o sexo do paciente usuário destes fármacos, permaneceram os mesmos.

Figura 6 - Comparação entre a dispensação dos medicamentos anorexígenos de acordo com o nome comercial e o ano do estudo.

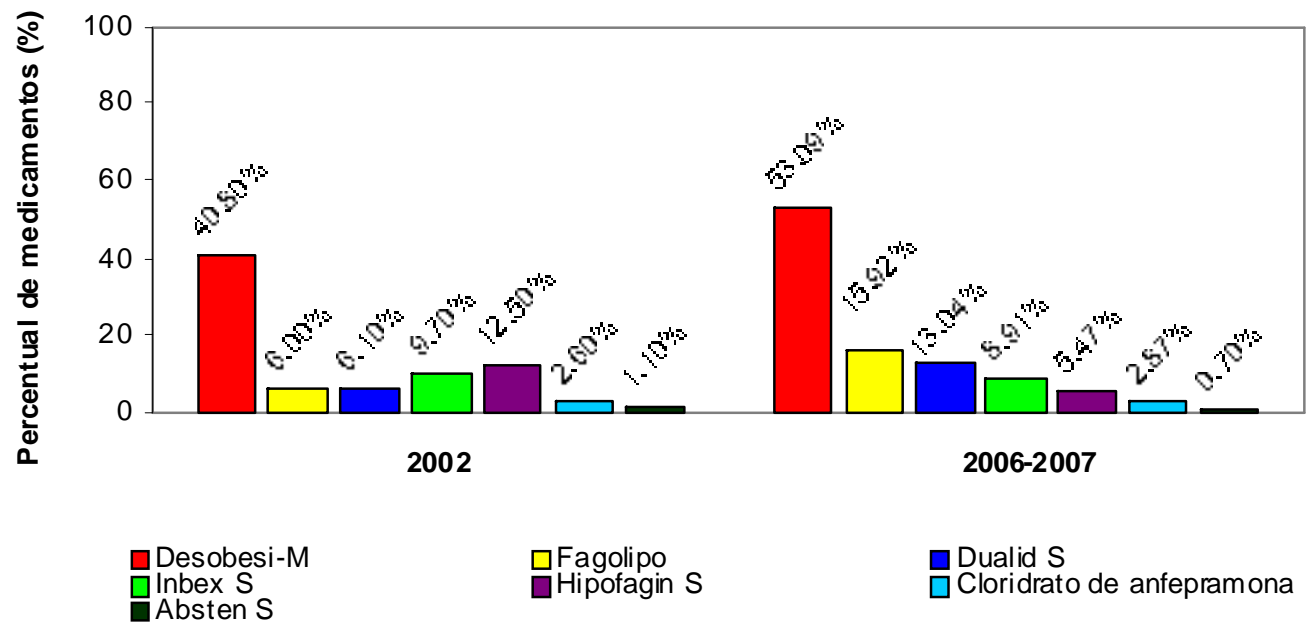

\section{CONCLUSÃO}

A pesquisa realizada na cidade de Santa Maria mostrou que é grande o consumo de medicamentos anorexígenos, principalmente pela população feminina. Além disso, foi encontrada a mesma tendência do estudo realizado em 2002, sendo os maiores responsáveis pela prescrição de anorexígenos os médicos clínicos gerais, o princípio ativo mais receitado o femproporex e o crescimento das vendas ocorre nos meses próximos ao início do verão, época em que as pessoas desejam perder os quilos obtidos durante o inverno.

\section{REFERÊNCIAS BIBLIOGRÁFICAS}

1. Behar R. Anorexígenos: indicaciones e interacciones. Rev Chilena de Neuro-psiquiatria. 2002, 40: 21-36.

2. Borges CBN, Borges RM, Santos JE. Tratamento clínico da obesidade. Simpósio: Distúrbios respiratórios do sono. 2006, 39 (2): 246-252.

3. Anfetamina. In: Wikipédia, a enciclopédia livre. Capturado em 15 de junho de 2007. Online. Disponível em http:// pt.wikipedia.org/wik/Anfetamina.

4. Mancine MC, Halpern A. Tratamento farmacológico da 
obesidade. Arq Bras. Endoc. Metab. 2002. 46 (5): 497-508.

5. Corrêa LL, et al. Avaliação do efeito da sibutramina sobre a saciedade por escala visual analógica em adolescentes obesos. Arq. Bras. Endoc. Metab. 2005, 49 (2): 286-290.

6. Wagner F, et al. Avaliação da dispensação de anorexígenos em farmácias comerciais de Santa Maria. XVIII Jornada Acadêmica Integrada. Santa Maria: UFSM, 2003.

7. Ministério da Saúde. Agência Nacional de Vigilância Sanitária. Portaria n. 344: Regulamento técnico sobre substâncias e medicamentos sujeitos a controle especial. Anvisa, 1998

8. Augello DE. Estimulantes do sistema nervoso central. Hiperatividade. Obesidade. Narcolepsia. Estimulantes respiratórios.
Farmacologia. 6 ed. Rio de Janeiro, Guanabara Koogan, 2002.

9. Lopes H, Paixão HH, Monteiro SL, Pedrosa RC. Formulações para emagrecimento: uso e abusos. Revista de Ciências Farmacêuticas. 1997, 2: 125-135.

10. Brasil, Conselho Federal de Medicina. Resolução n. 1477 de 11 de julho de 1997. Veda aos médicos a prescrição simultânea de drogas tipo anfetaminas, com um ou mais dos seguintes fármacos: benzodiazepínicos, diuréticos, hormônios ou extratos hormonais e laxantes, com finalidade de tratamento da obesidade ou emagrecimento. Diário Oficial da União, Brasília, DF. Capturado em 16 julho de 1997. Disponível em http://elegis.bvs.br/leisref/public/showAct.php?id= 6320

Endereço para correspondência:

Andrieli Cassel Feltrin

Rua João Lens, 199.

CEP: 97090-360, Santa Maria - RS - Brasil.

Fone: (55) 3025-7348/ 9968-5500.

E-mail: andrieli.cf@gmail.com 